
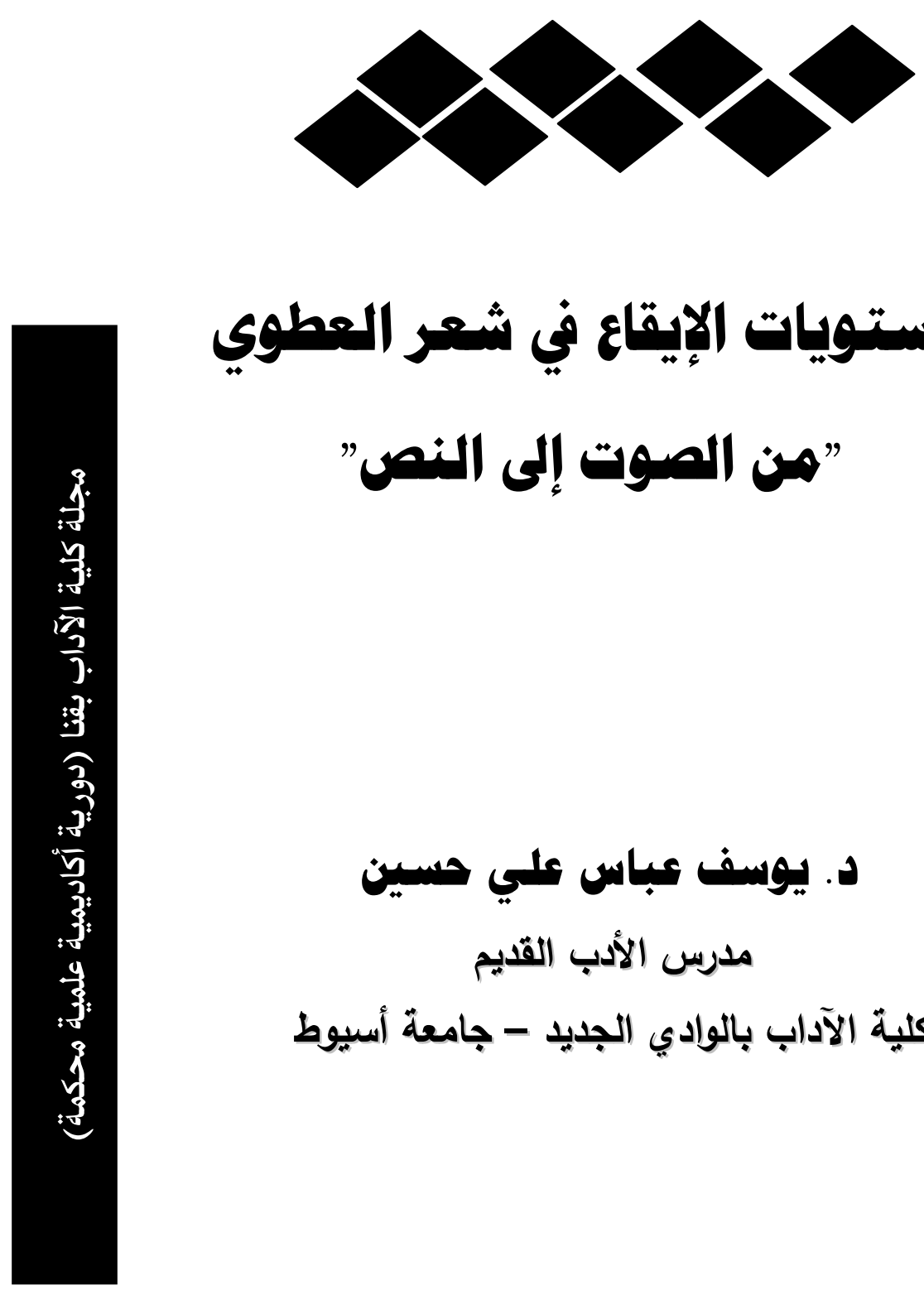

$$
\begin{aligned}
& \text { هستويات الإيقاع في شعر العطوي } \\
& \text { "هن الصوت إلى النص" }
\end{aligned}
$$$$
\text { د. يومسف عباس علي حسين }
$$$$
\text { مدرس الأدب القديم }
$$

كلية الآداب بالوادي الجديد - جامعة أسيوط 
مُستويات الإيقاع في شعر العطوي "من الصوت إلى النص" ـ 
الحمد الله الذي أنعم على الإنسـان بنعم خصـه بها و في مقدمتها اللسـان الفصيح

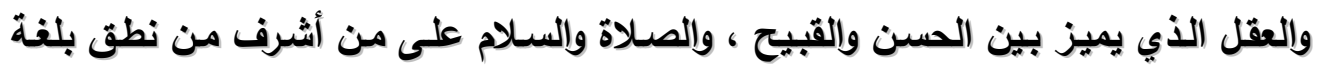

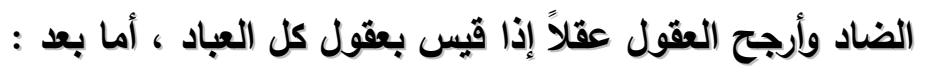

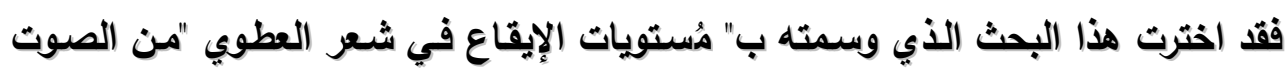

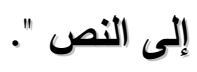

ويقصد بالإيقاع: هو أي صوت يتكرر أو يحدث تتابع زمني محدد ومنتظم ، مهما

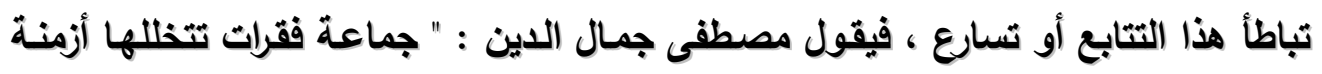

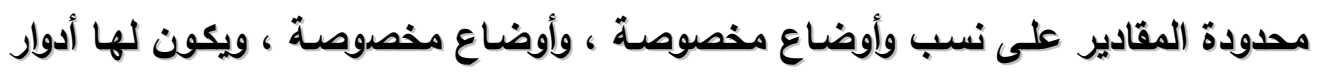

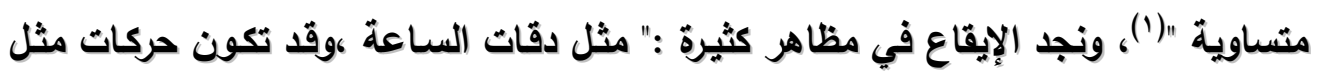

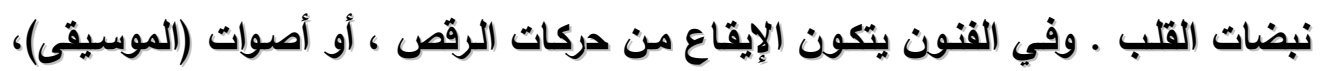
أو ألفاظ (الشعر) (ץ). وجاء بمعنى حسن اختيار الألفاظ من حيث حروفها وانتظامها وصيغتها ومقاديرها

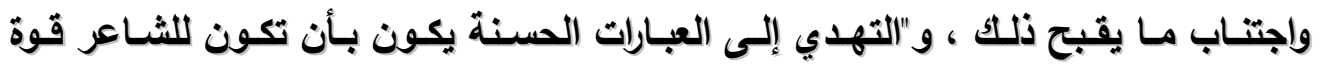
يستولي فكره بها على جميع الجهات التي يستكمل حسن الكلام بالترامي بـه إلى كل جهية منها والتباعد عن الجهات التي تضادها ـ وتلكك الجهات هي اختيار المواد اللفظية أولاً من كن فئن

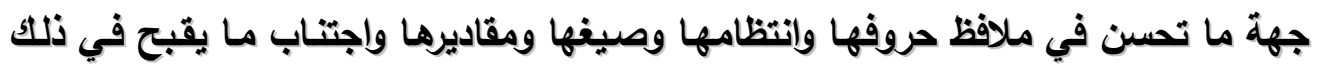

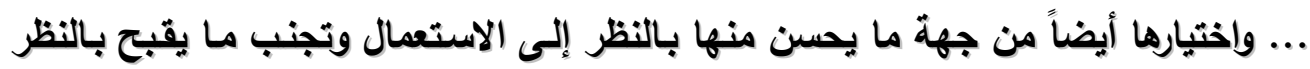

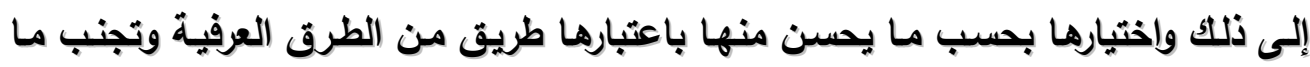

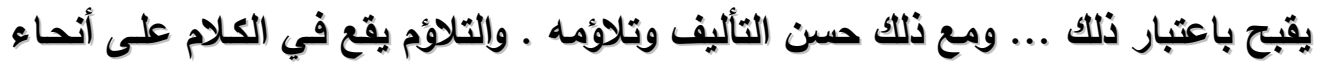

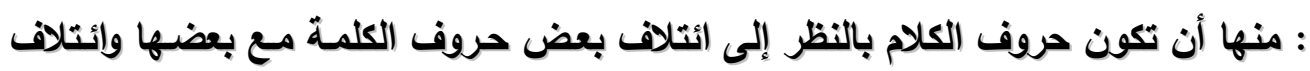

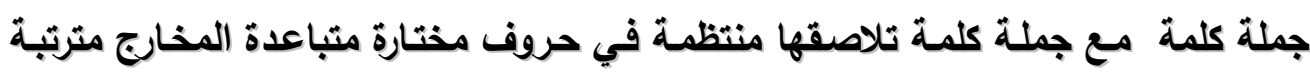

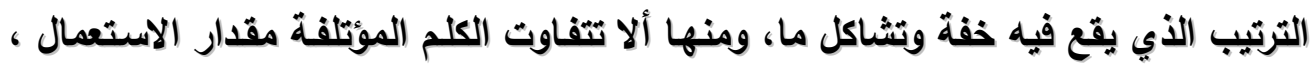
فتكون الواحدة في نهاية الابتذال والأخرى في نهاية الحوشية وقلة الاستعمال.

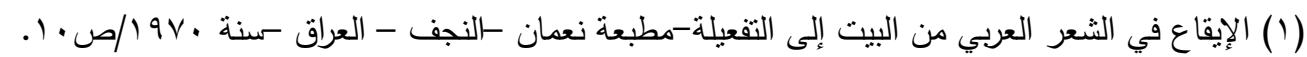

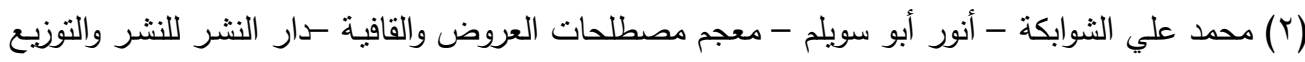


ومنها أن تتناسب بعض صفاتها مثل أن تكون إحداهما مشتقة من الأخرى مـع تغاير

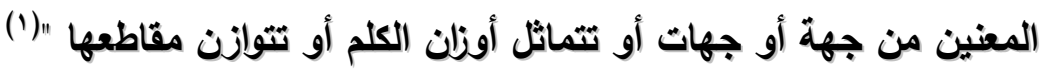

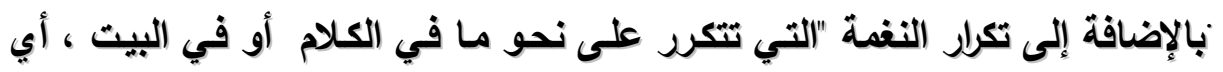
توالى الحركات والسكنات على نحو منتظم في فقرتين أو أكثر من فقر الكئل الكام أو في أبيات

القصيدة "(†) القركات

وتوجد علاقة وطيدة بين الإيقاع والشعر الموزون ، فهو أسساس من أسس جودة

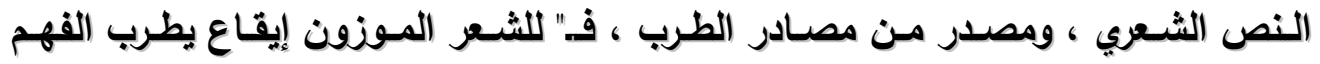

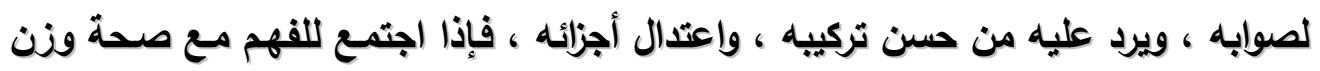

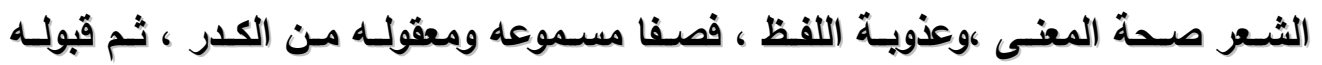

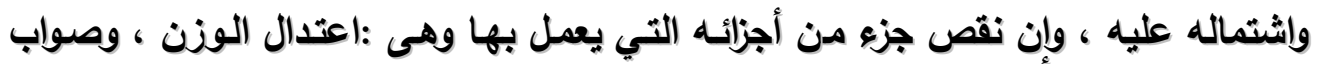
المعنى ، وحسن الألفاظ ، كان إنكار الفهم إياه على قدر نقصان أجزائه ومثال ذلتك الغناء

المطرب الذي يتضاعف له طرب مستمعه ،المتفهم لمعناه ولفظه مع طيب ألحانه (r).

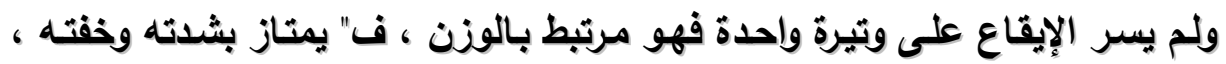

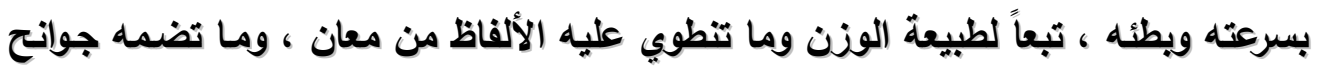

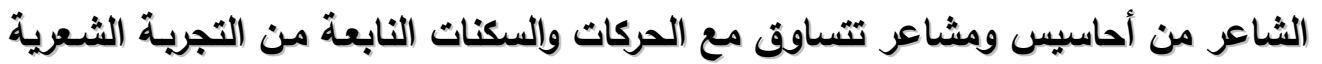

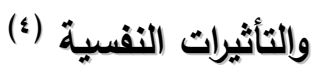

وللإيقاع دور مهم في كثف الصراع الداخلي في القصيدة ، " والإيقاع إذن لا يحاكى

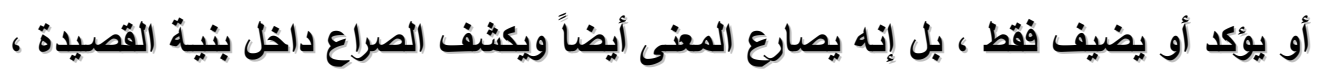

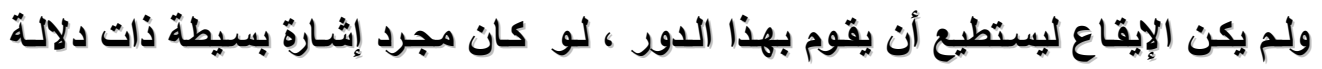

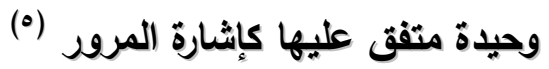

(1) حازم القرطاجني منهاج البلغاء وسراج الأدباء - تحقيق محمد الحبيب بن الخوجة -الدار العربية للكتاب

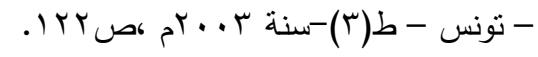

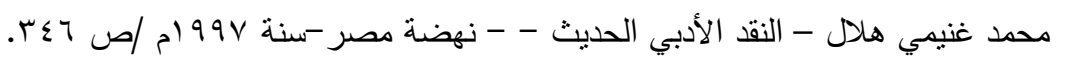

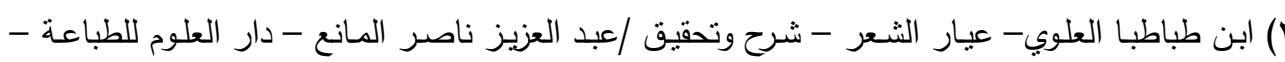

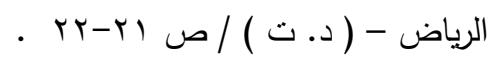

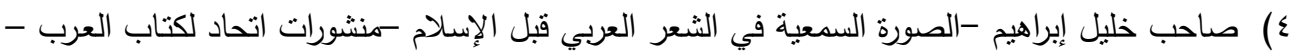

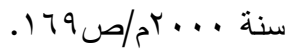

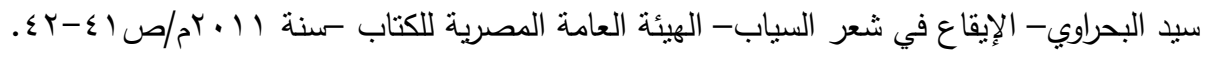


د. يوسف عباس علي حسين

فهو يعطي للشعر حيويـة ويبعده عن الرتابة والملل ، فيقول كمـال أبو ديب : "لقد

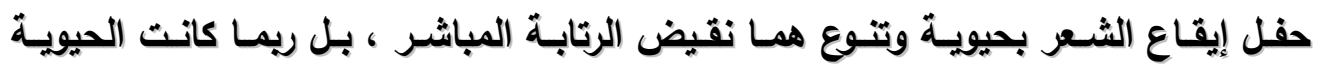

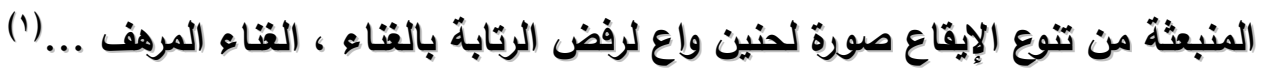

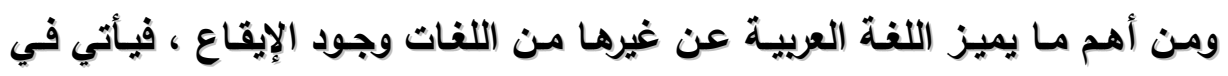

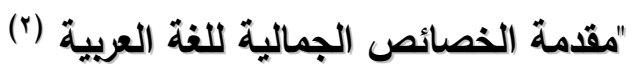

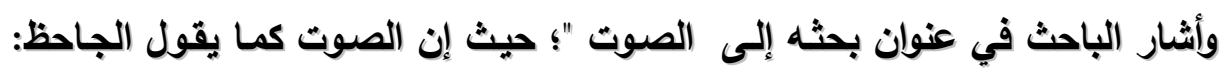

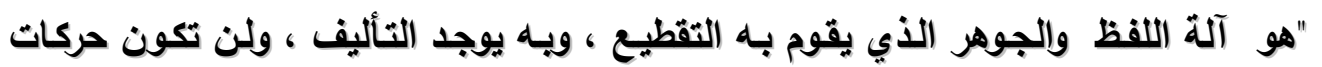

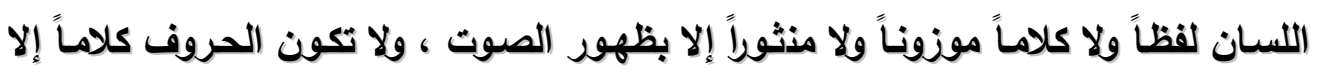

بالتقطيع والتأليف . وحسن الإشارة باليد والرأس ، من تمام حسن البيان باللسان "((ז).

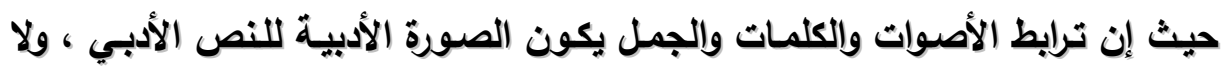
ننكر أن الصوت يشكل قيمة جمالية وإيقاعية في النص الأدبي.

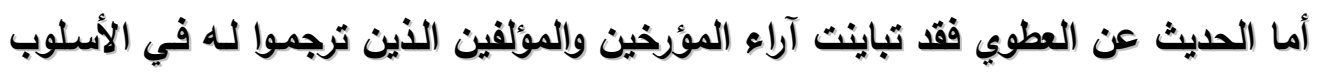

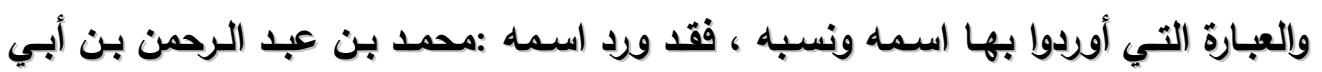
عطبة) ؤ) وقيل : محمد بن عبد الرحمن العطوي(0) ، وقال آخر بأنه : أحمد بن إبراهيم بن أبي

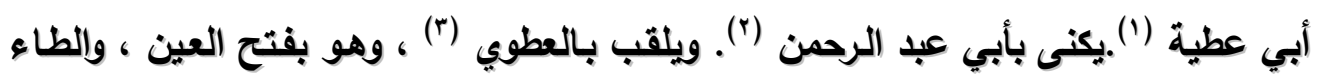

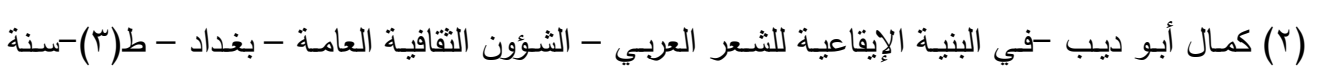

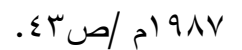

$$
\begin{aligned}
& \text { (ץ) عبد الفتاح صـالح نـافع -عضـوية الموسيقى في النص الثـعري -مكتبـة المنـار - الأردن ط(1)-سـنة } \\
& \text {. }
\end{aligned}
$$

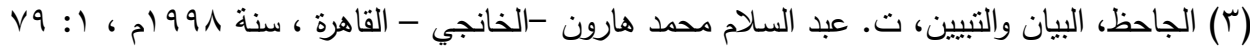

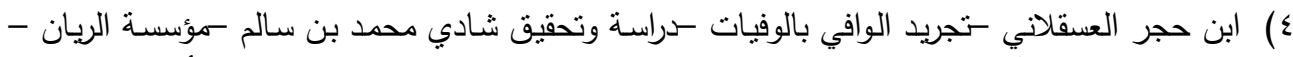

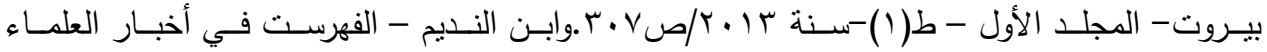

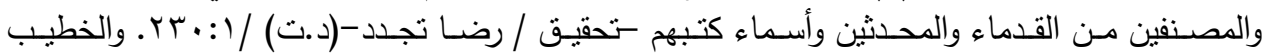

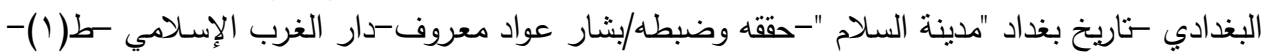

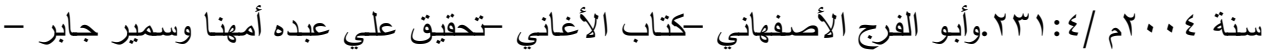

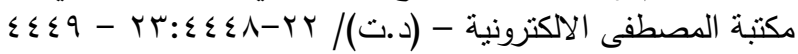

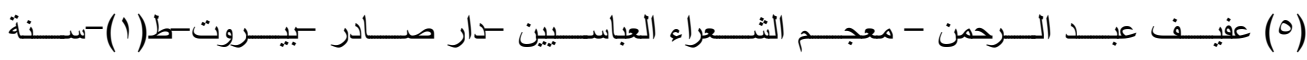

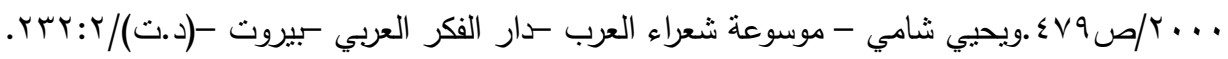

$$
\begin{aligned}
& \text { - rV. - }
\end{aligned}
$$


مُستويات الإيقاع في شعر العطوي "من الصوت إلى النص" ــ

والطاء المهملتين ، وفي آخرها الواو ، هذه النسبة إلى عطية ، وهو اسم الجد المنتسب

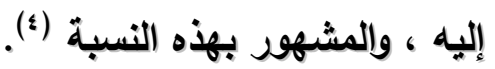

كان ولاؤه لقبيلة كنانة ، وهى قبيلة عربية معروفة يرجع نسبها إلى "كنانة بن خزيمـة

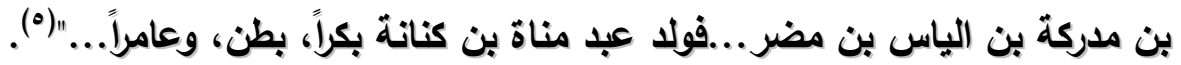

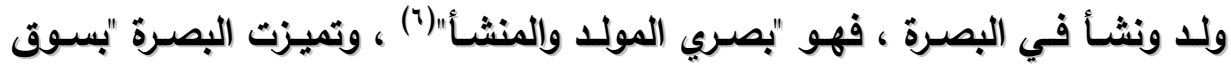

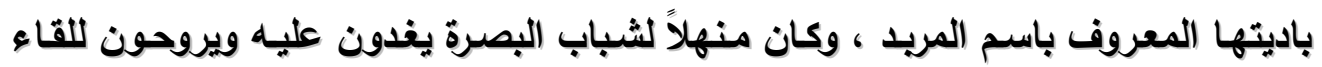

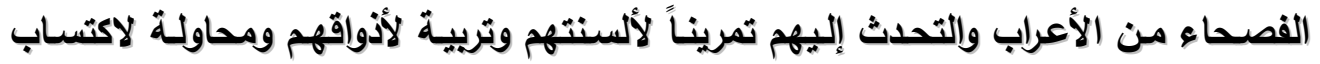

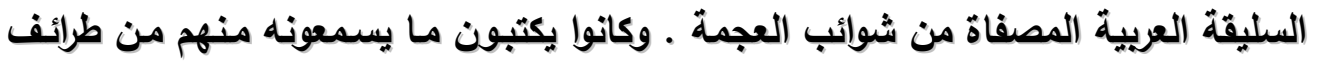

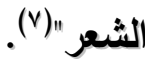

وكان العطوي من "ثعراء الدولة العباسية"(^) كما يعد من "متكلمي المعتزلة ، يذهب

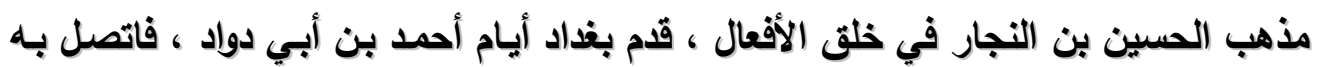

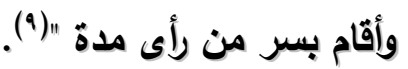

أما عن مولده تذكر لنا المصادر صراحة تاريخ مولداه ، ولكن توجد بعض الإشـارات

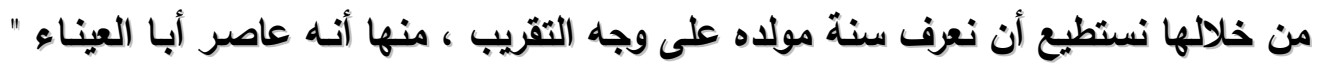

( (1) صلاح الدين الصفدي —الوافي بالوفيات -تحقيق أحمد الأرناؤوط -نركي مصطفى - دار إحياء التراث

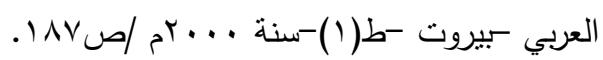

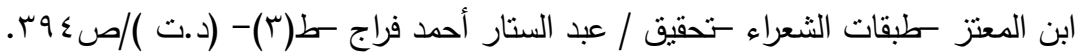

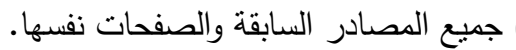

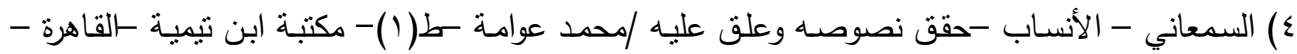

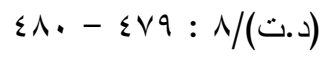

(0) هشـام الكلبي -جمهرة النسب ستحقيق / ناجي حسن - عالم الكتب - مكتبـة النهضـة - ط(1)-سنة

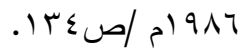

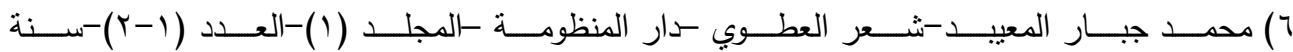

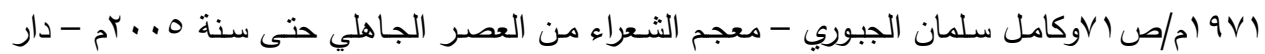

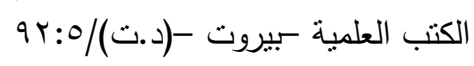

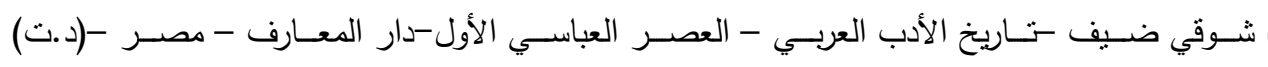


د. يوسف عباس علي حسين

محمد بن القاسم بن ياسر الهاشي ، بالولاء ، أديب فصيح من ظرفاء العالم ، ولد سنة

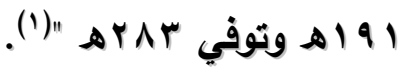

وتوجد له مقطوعة رثى فيها" آل برمك "بعد نكبتهم ، وكانت نكبة البرامكة في أيام الرشيد

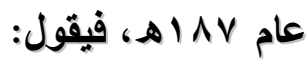

وَعَيْنِ للخليفة لا تَََامُ

كما للناس بالحَجَرَ اسنتِِلَام

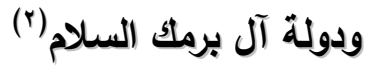

مما سبق نلاحظ أن العطوي ولد في أغلب الظن في أواخر القرن الثاني الهجري.

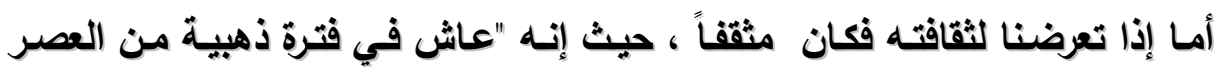

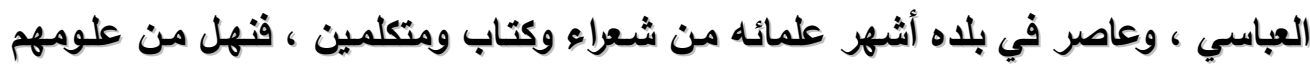

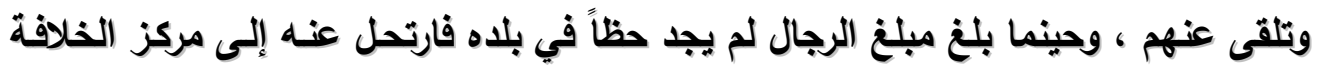

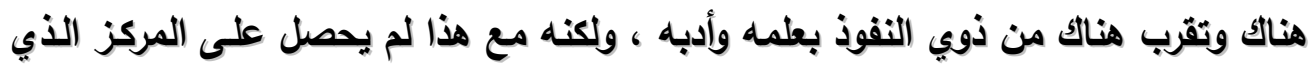

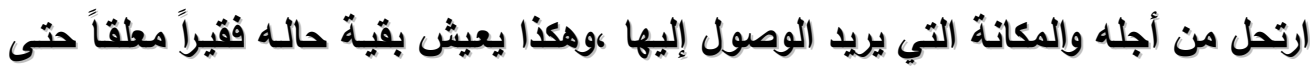

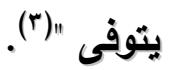
وكان لله باع كبير في المناظرة " وحدث المرزياني عن محمد بن عطية الثـاعر ، قال

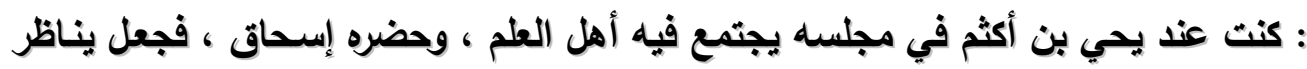

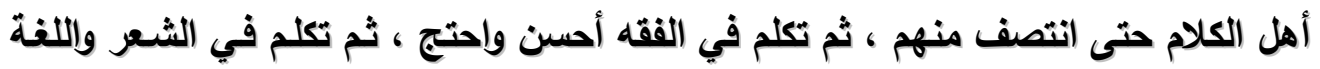

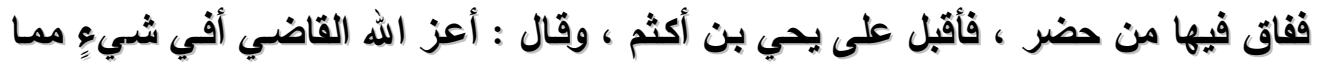

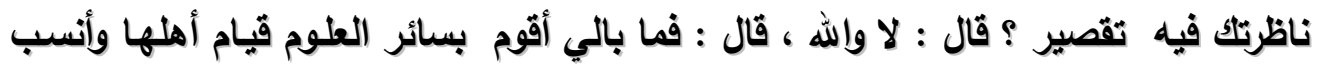

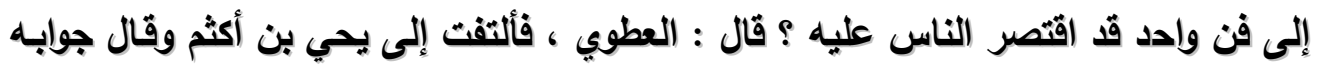

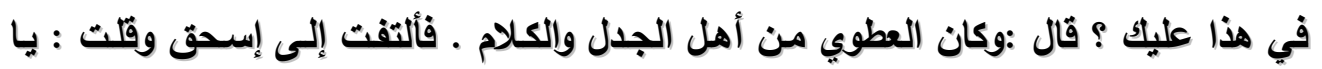

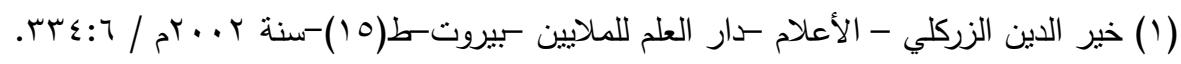

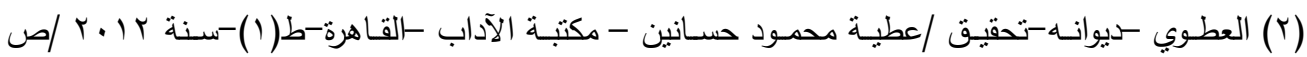
$.109-101$

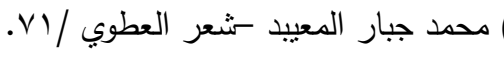


مُستويات الإيقاع في شعر العطوي "من الصوت إلى النص" ــ

أبـا محمد أخبرنـي إذا قيل من أعلم الناس بالثعر واللفة ؟ أيقولون إسـاق أم الأصمعي

وأبو عبيدة "(1)

وكان يحضر مجلس سيف الدولة ، و"حضر أبو العباس الصفري مجلس سيف الدولية

وعنده القاضي أبو حفص قاضي حلب فجرى ذكر البيتين المشهورين وهما :

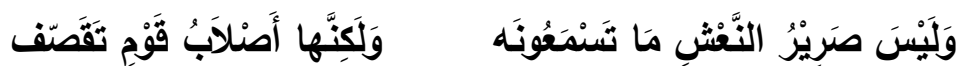

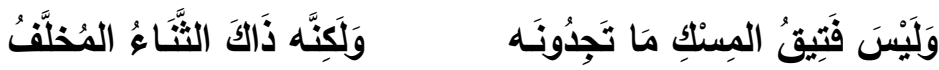

فاستحسنا وقال سيف الدولـة : هما لبعض المحدثين وذهب عني اسـمه ، فقـال

القاضس :هما للخنساء قال سيف الدولة للصفري : أتعرف لمن هما ؟ قال : نعم ، هما

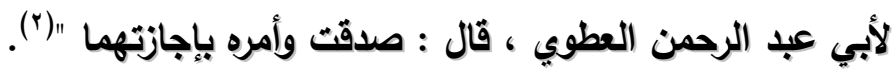

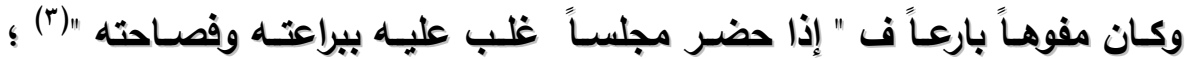

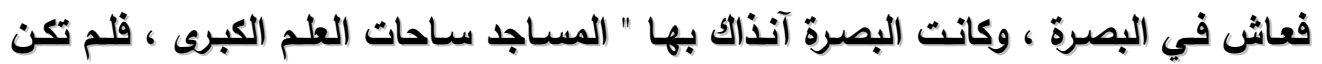

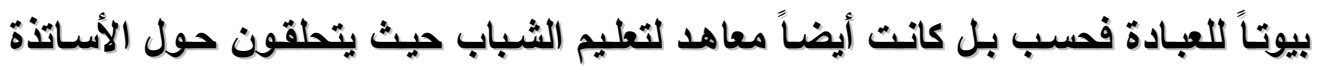

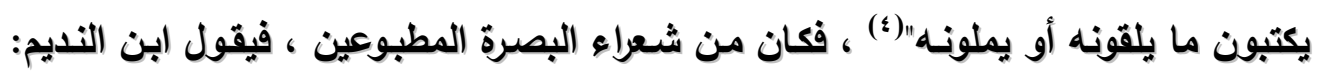

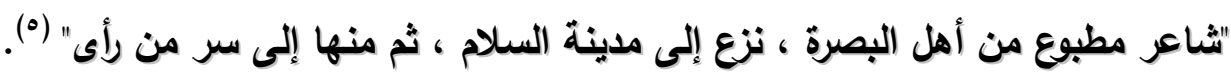

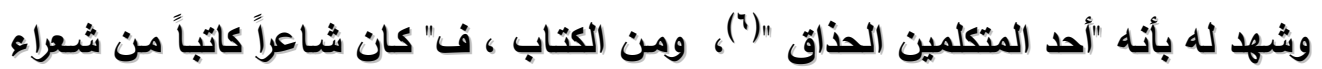

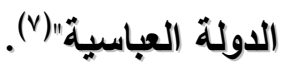
أما عند الحديث عن مذهبه ف"كان العطوي معتزلياً " (^) ، والمعتزلة هي : "أهم فرقة يدين

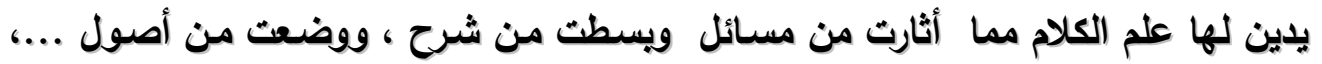

$$
\begin{aligned}
& \text { (1) ياقوت الحموي - معجم الأدباء - تحقيق إحسـان عباس -ـار الغرب الإسـلامي - بيروت-ط(1) (1)سنة } \\
& .097: 1 / 51994
\end{aligned}
$$

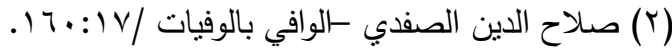

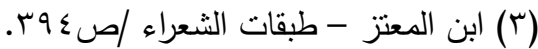

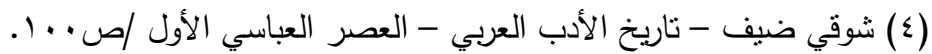

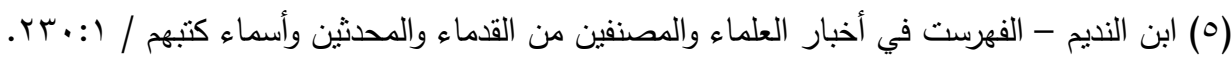

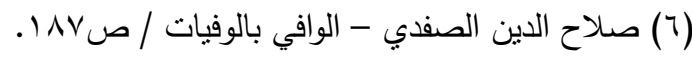

$$
\begin{aligned}
& \text {. أبو الفرج الأصفهاني - كتاب الأغاني / (Y) }
\end{aligned}
$$

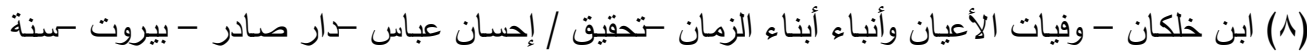

$$
\begin{aligned}
& \text { r } 9: 7 / \text { / } 19 \vee r
\end{aligned}
$$




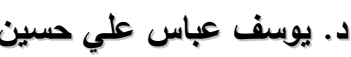

وللمعتزلة مبادئ يكادون يشتركون فيها جميعاً ، ومبادئ خاصـة ببعض رؤسائهم "( (1)، ولهـ

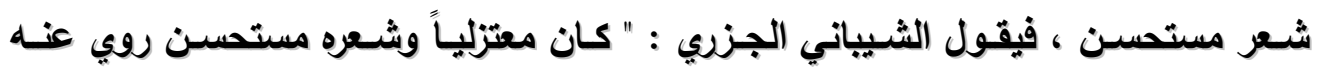

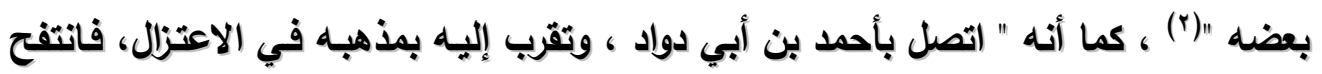

باه وأغناه "(").

ولم تذكر المصادر من قريب أو بعيد شيئاً عن أسرته سوى ما نسب عن أبيه وجده ، وذكر

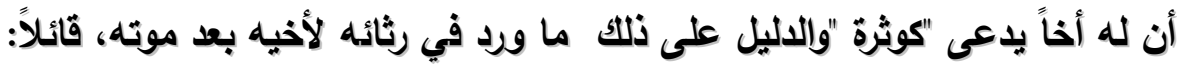

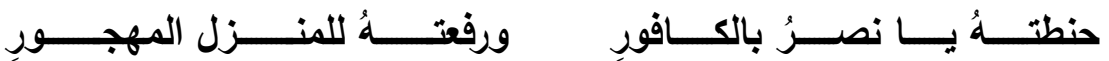

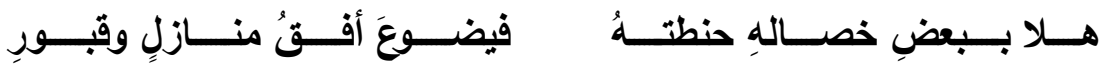

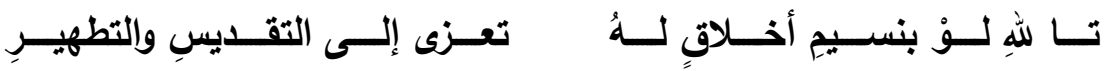

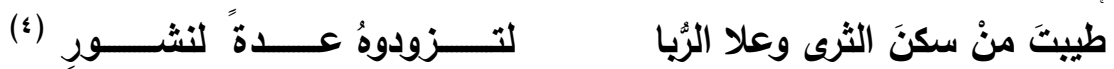

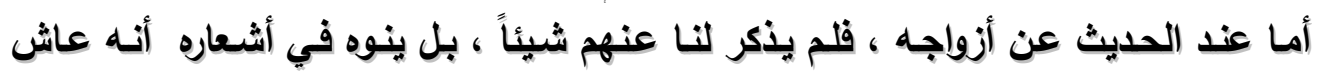

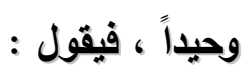

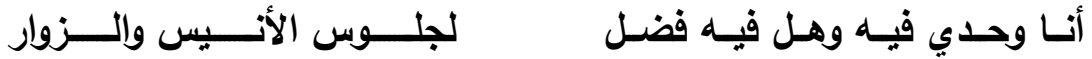

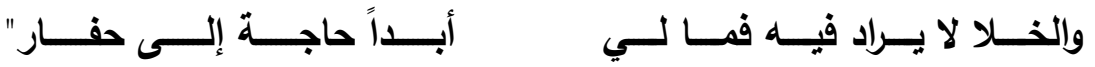

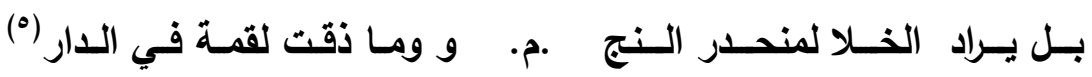
أما عن أولاده ، فقد ورد في أشعاره أن له أولاداً صغاراً يشكون الفقر والجوع ويرد الثتاء

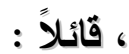
أنا طرح بين خلا .م. ت حديدات النصال بين دين وشتتاء وللعطوي مؤلفات ذكرها ابن النديم ، هي :

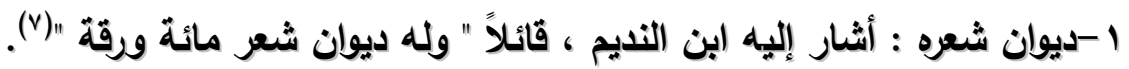

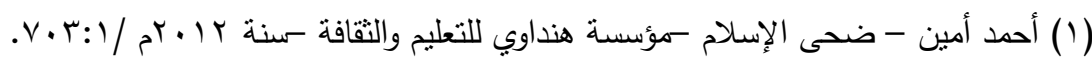

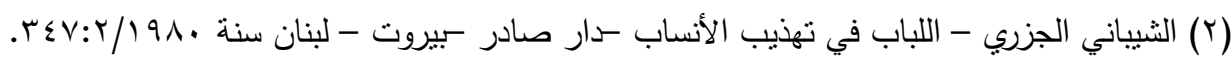

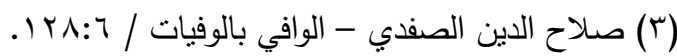

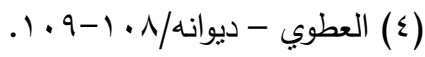

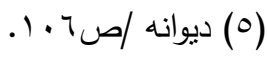

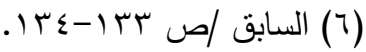

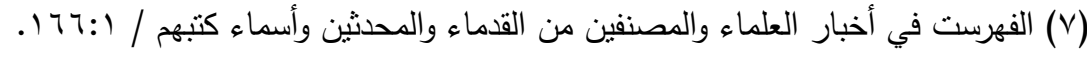
- rV 
مُستويات الإيقاع في شعر العطوي "من الصوت إلى النص" -

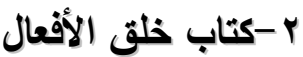

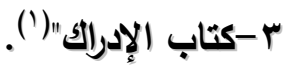

وقال محقق الديوان: لم استطع الوقوف على هذين الكتابين ، ولا أدري هل طُبعا أم نُشرا؟

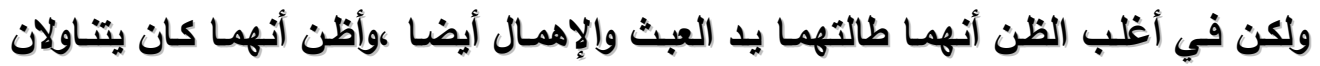

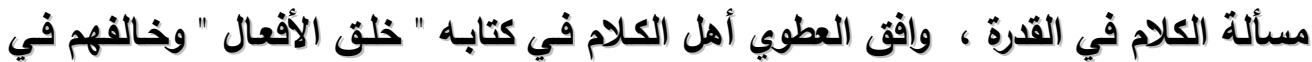
كتابه الإدراك () مساله

ولم تثر المصادر صراحة إلى تاريخ وفاته، كما أكتفف الغموض تاريخ مولده ، ولكن ذكر الأصفهاني : " حدثي أبو يعقوب إسـاق بن الضـحاك بـن الخصيب الكاتب، قـال:

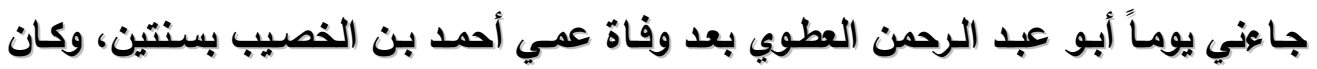
صديقه وصنيعه، فجلس عندي يحادثي حديثه ، ويبكي سـاعة طويلة ثم تغيمت السماء

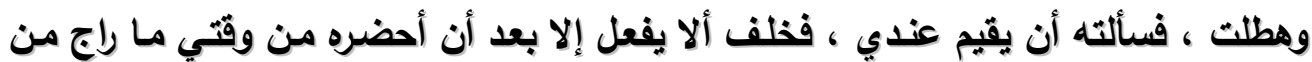

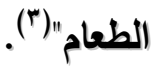

وذكر ابن العماد الدمشقي أنه في " خمس وستين ومـائتين فيها توفى أحمد بن الخصيب

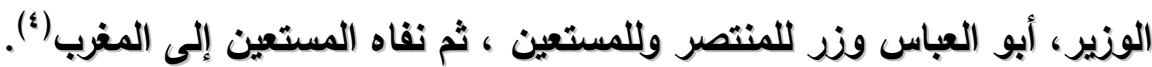

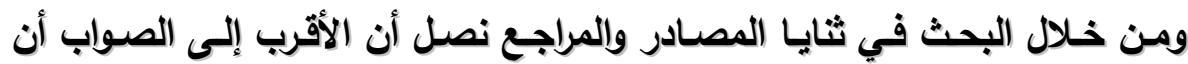
العطوي ولد في الربع الأخير من القرن الثاني الهجري ، وتوفي في النصف الثاني من القرن الثالث الهجري.

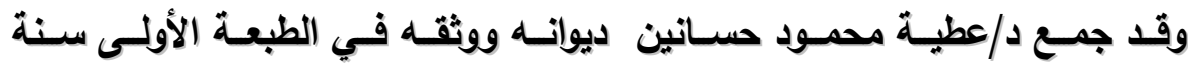

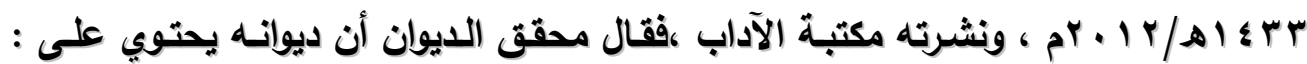

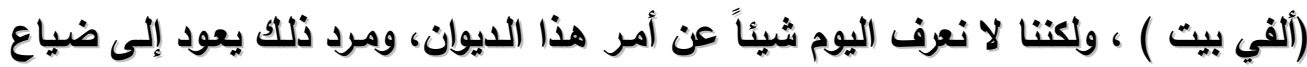

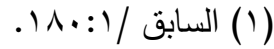

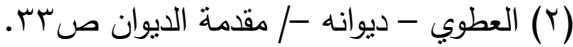

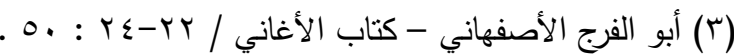

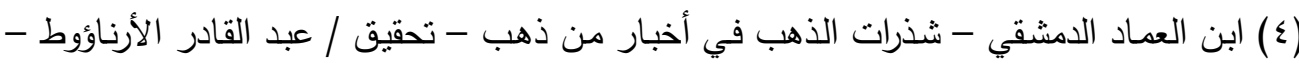

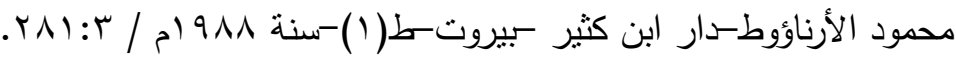


د. يوسف عباس علي حسين

القسم الأكبر من شعره وإندثاره ، ولم يذكر محقى الديوان لنا صراحة عدد الأبيات التي قام

بجمعها من بطون الكتب(')

\section{-بيئته الثقافية :}

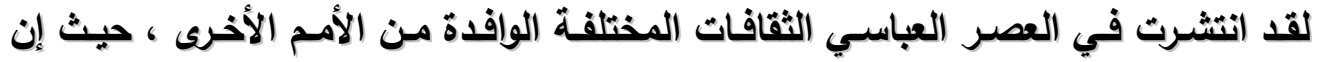

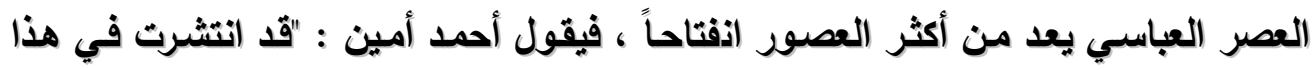

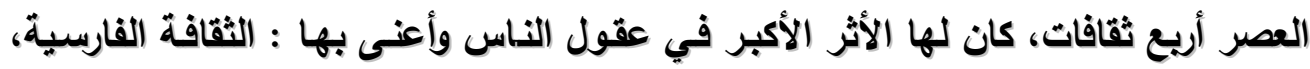

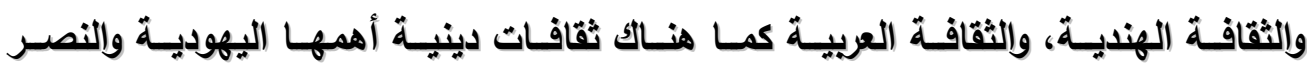

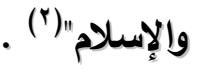

كما وجدت نهضـة في مجال الأدب ،حيث إن الخلفـاء شجعوا الأدب والأدبـاء والعلم

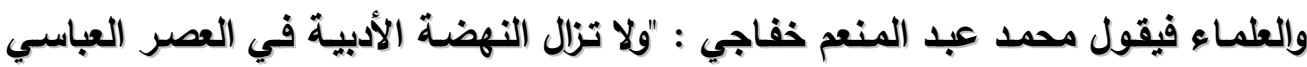
محل بحث الباحثين ودرس الدارسين ، ولم تكثف عقول العلمـاء حتى اليوم عن أسرارها

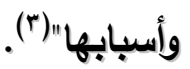

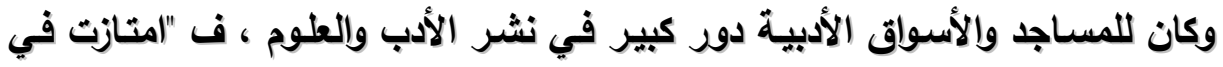

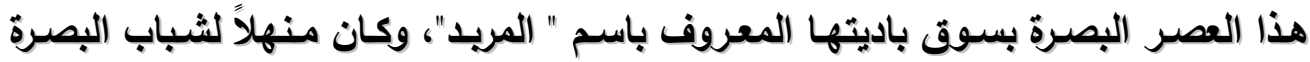
يذدون عليه ويروحون للقاء الفصحاء من الأعراب والتحدث إليهم تمريناً لألسنتهم وتربية بادية

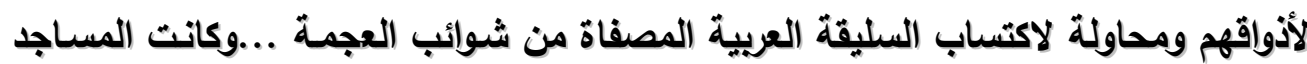

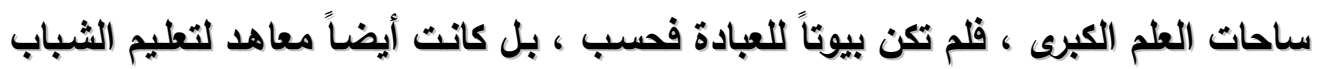

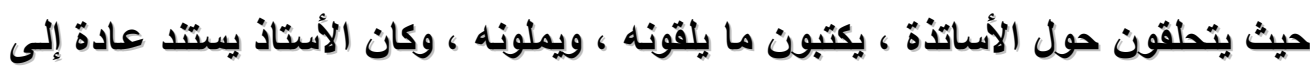

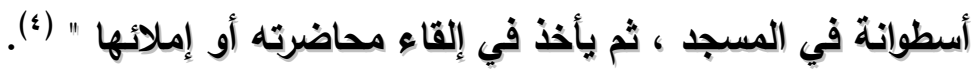

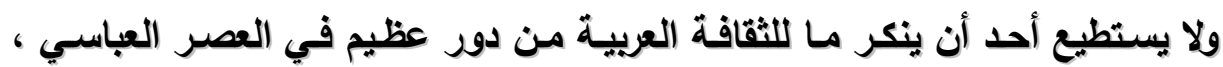

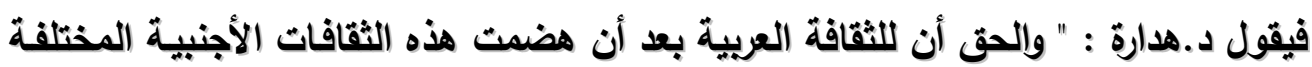

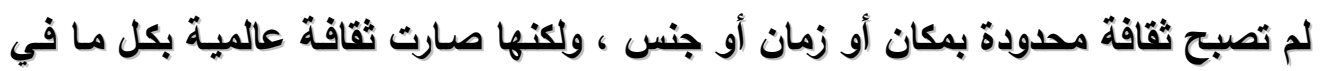
هذا التعبير من معان .

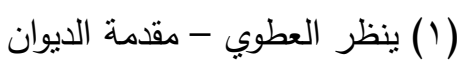

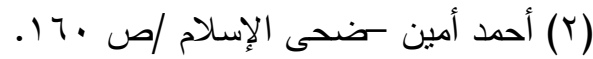

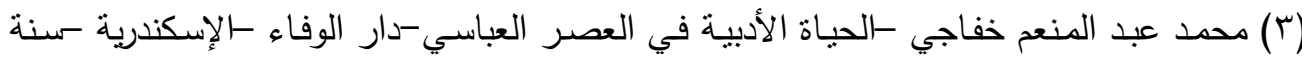

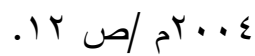

$$
\begin{aligned}
& \text { (؛) شوقي ضيف- تاريخ الأدب العربي - العصر العباسي الأول /ص . . 1. } \\
& \text { - rVT . }
\end{aligned}
$$


إنها لم تصبح ملكاً للعرب وحدهم ولا الفرس ولا اليونـان أو الهنود أو السريان ولكنها

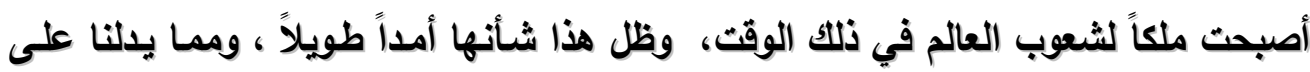

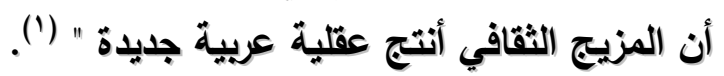

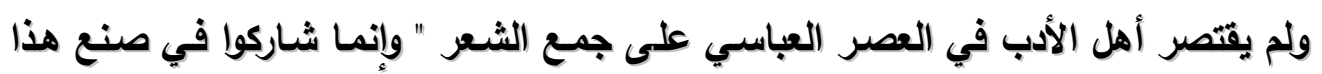

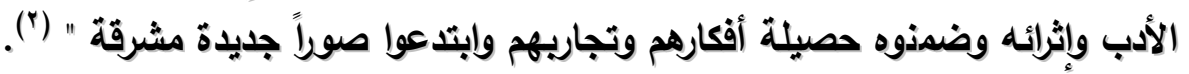

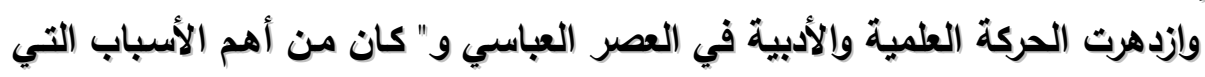

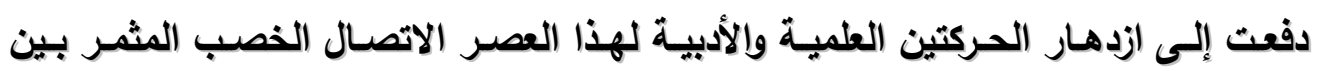

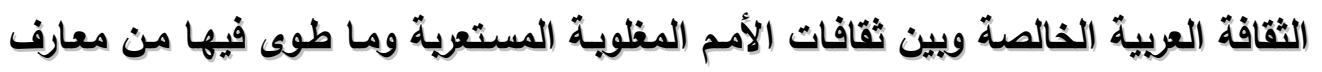

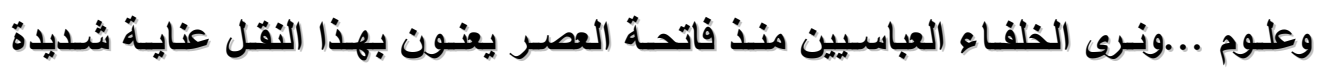

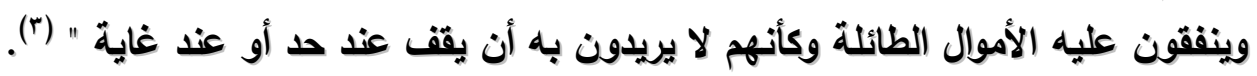

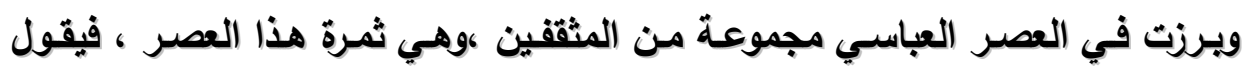

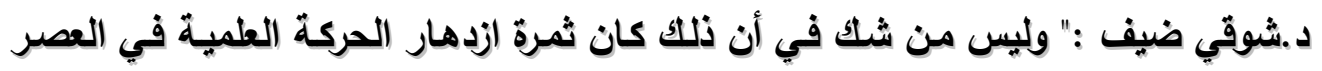

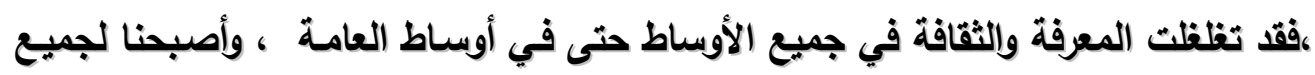

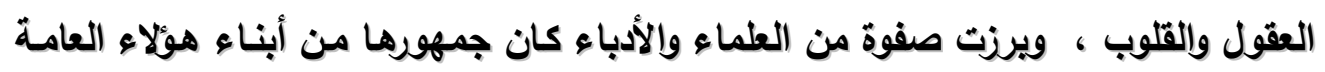

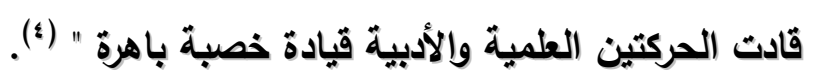

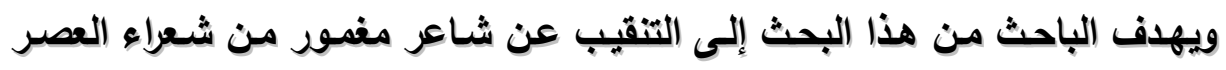

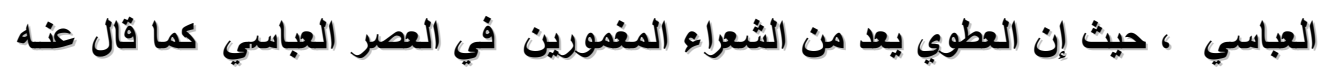

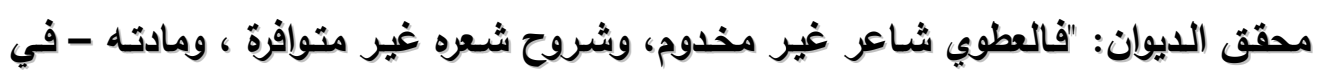

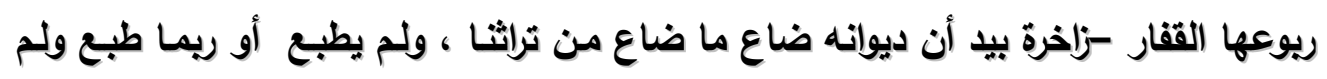

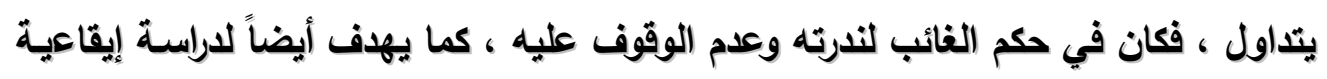
المعاني في شعره ومُستويات الإيقاع.

$$
\begin{aligned}
& \text { (1) محمد مصطفى هدارة - اتجاهات الثعر العربي في القرن الثاني الهجري-دار المعارف - مصر }
\end{aligned}
$$

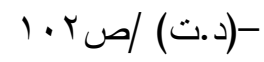

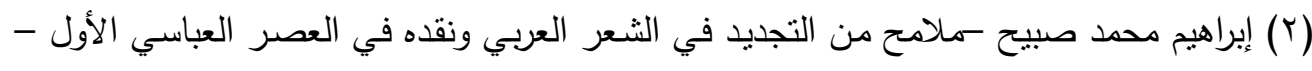

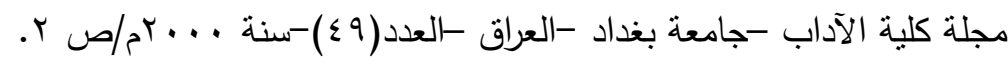

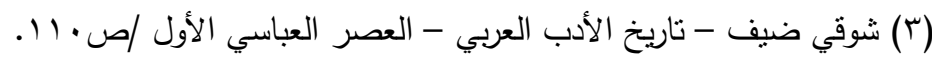

$$
\begin{aligned}
& \text { (ك) السابق /ص 1. 1. }
\end{aligned}
$$


د. يوسف عباس علي حسين

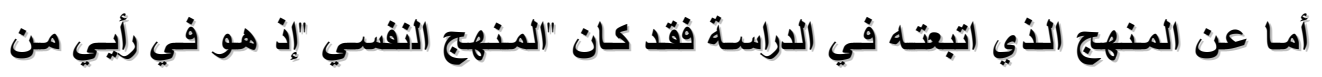
أنسب المناهج للبحث ، حيث يكثف غوامض وخبايا العمل وصاحبه ، وتفسيره من كل جوانبه وحل مشكلاته وتتاقضه.

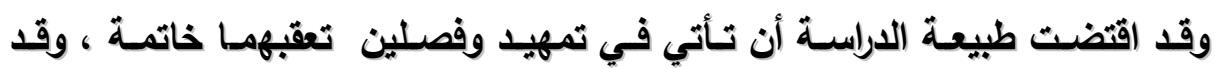

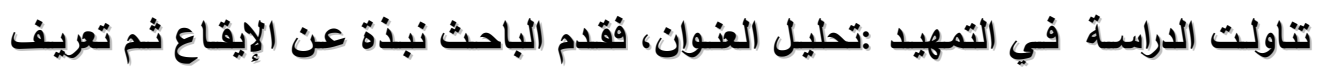
بصاحب الدراسة ( العطوي )والمنهج المتبع في الدراسة. - الفصل الأول: تناول شعر العطوي مضامينه الفنية (إيقاعية المعاني في شعره )..

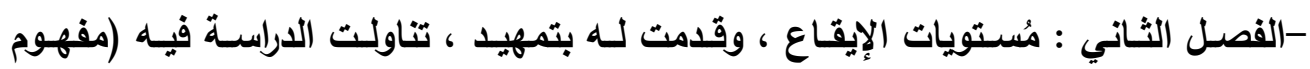

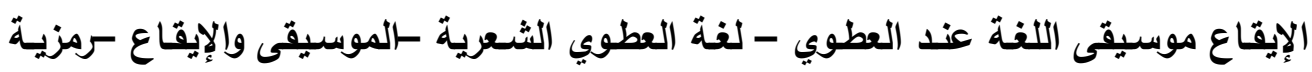
(الأصوات ) - مُستويات الإيقاع : تناولت الدراسة فيه التالي :

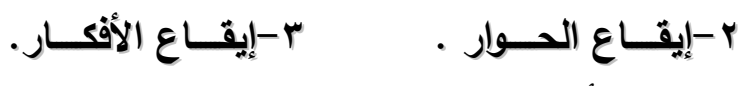

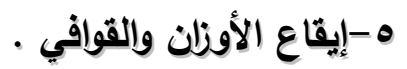

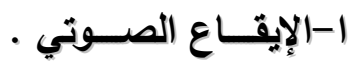

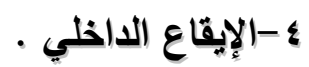
وقد رجوت من خلال هذه النقاط استيفاء مـا يمكن من فنيات الإيقاع عند الثـاعر العطوي

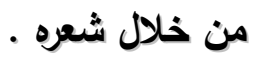


الفصل الأول

شعر العطوي : مضامينه الفنية (إيقاعية المعنى في شعره)

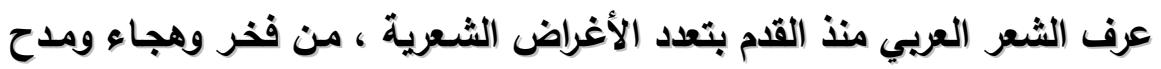
ورثاء ووصف وغيرها من الأغراض التي خاض فيها الشعراء قديماً وحديثاً ، فكانت قديماً

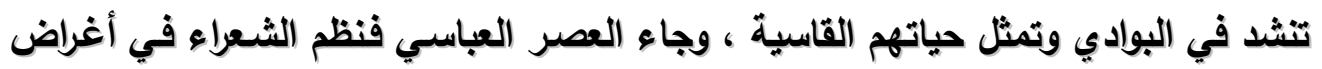

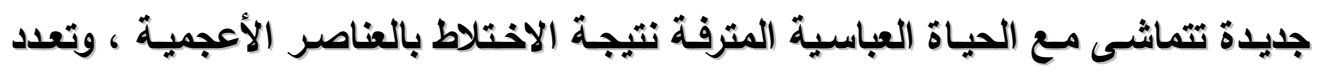

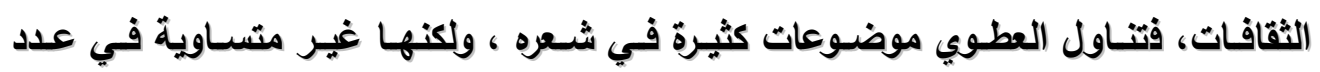

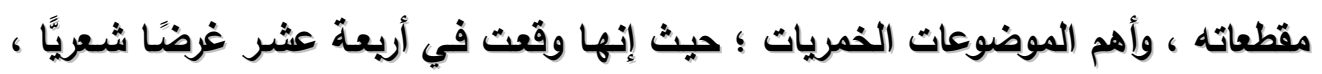

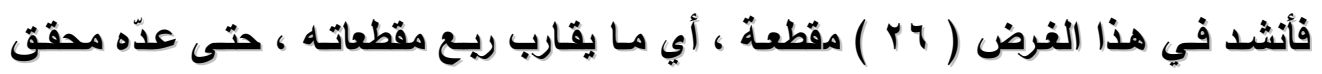

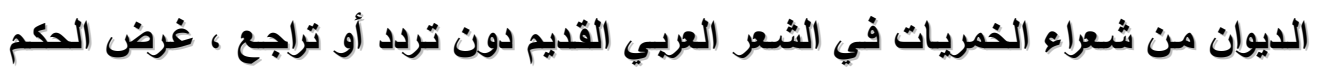

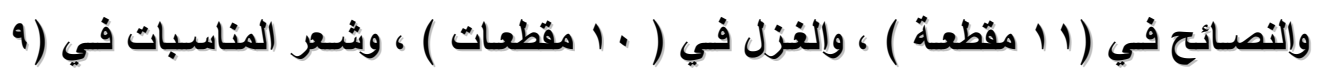

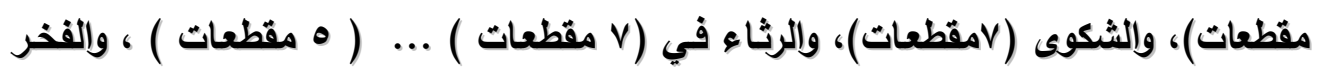

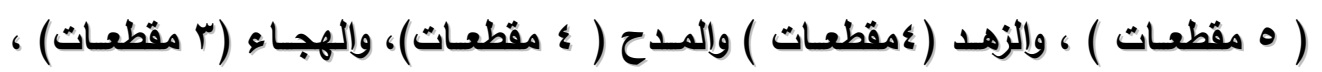
والوصف ( r مقطعات) ، والثبب في مقطعة وإحدة ، وشعر أهل الكلام في مقطعة أيضًا .

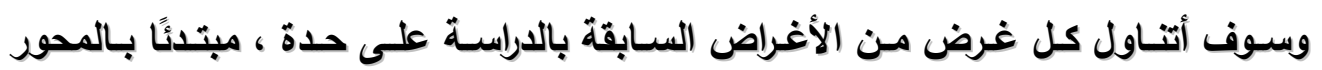

$$
\text { الرئيس في شعره . }
$$

- الخمريات ووصف مجالسها: كان هذا الغرض غالب في شعره ، حتى قال عنه شهاب الدين النويري : كان مولعًا

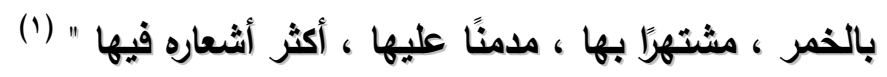

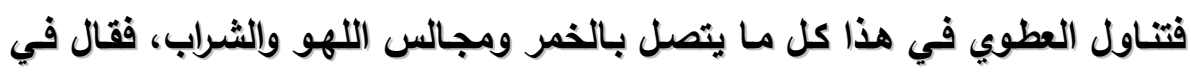
الراح واستطابتها واستدفاع الغم بها :

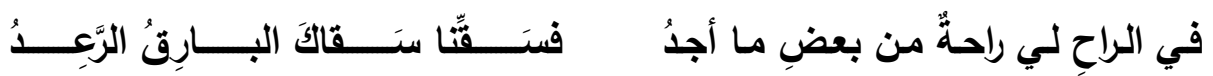

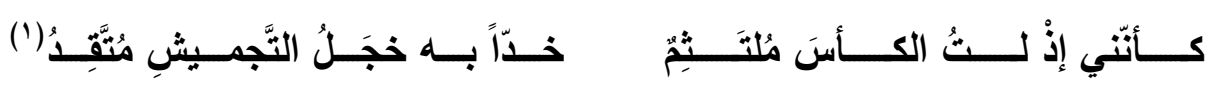

$$
\text { (1) ينظر : نهاية الإرب في فنون الأدب - دار الكتب العلمية- بيروت ، سنة ع ـ. بم ، ـ : } 91 .
$$
- rvq 
فهو يقبل الكأس وسلابها ، وكأنه يقبل خدًا شديد الحمرة متقةًا وقال في وصف الخمر :

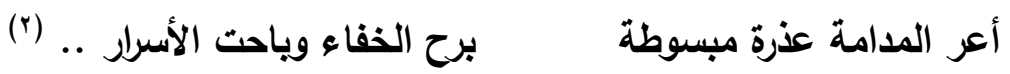

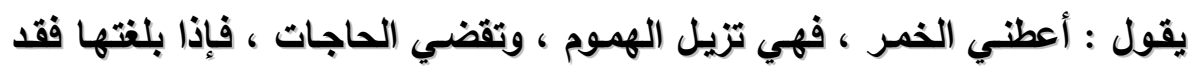

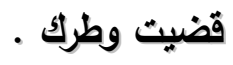
وقال في أفضل أوقات الخمر : مان

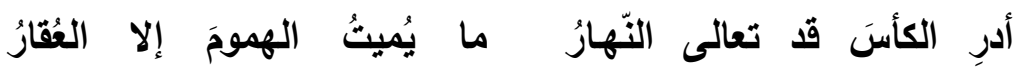

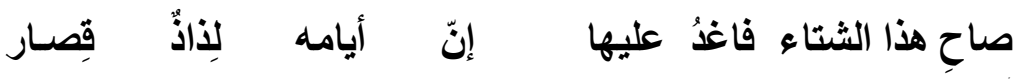
أي شيء ألذ من يوم دجنٍ هيه كأسُ على الندامى تُارُ

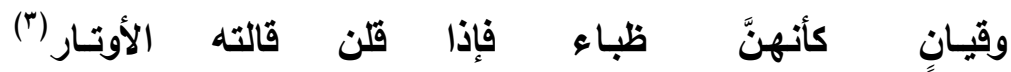
يستعجل في شرب الخمر ؛ لأن النهار قصير ، فهي تُدار على الجميع ( أي الذين

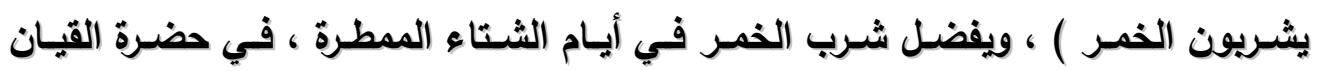
الحسان .

وقال في وصف مائدة من موائد الشراب :

والماءُ من برد ريحه خَصرُ

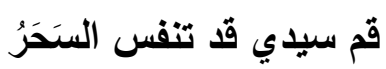
موقوفة والشقاوة تنتظر والراح قد صفعت أبارقها لولا الندر طار حولها شرز وزهرةٌ أشرقت مصابحها

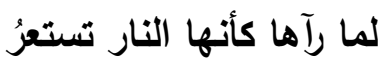

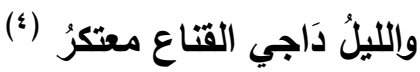
دَنا إليها في الليلِ مقتبسُ

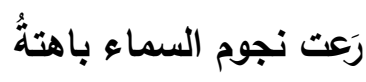

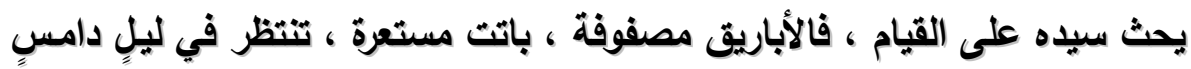
، طالت ظلمته ، واشتت برده ، والسقاة ينتظرون بعيونٍ ساهرة .

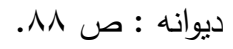

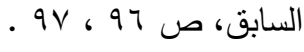

$$
\begin{aligned}
& \text { (Y) } \\
& \text { ديوانه : ص } 90 \text { - } 90 .
\end{aligned}
$$


وقال مستقبحًا شراب الراح في وسط النهار ، سـاخطًا عليه ، حثًا على تناوله في

أول النهار ، وسط الغناء والرياض:

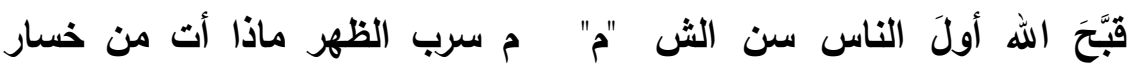

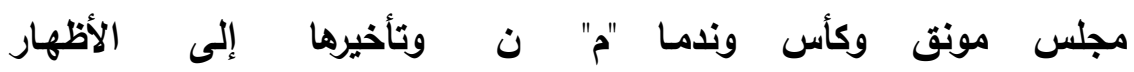

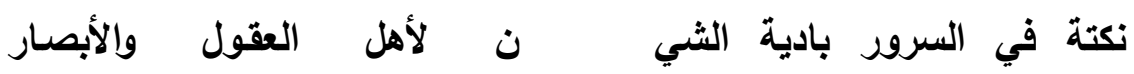

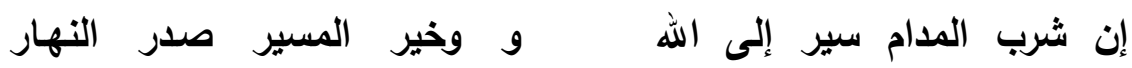

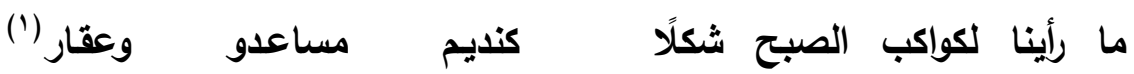

وقال بمجد الكأس والراح :

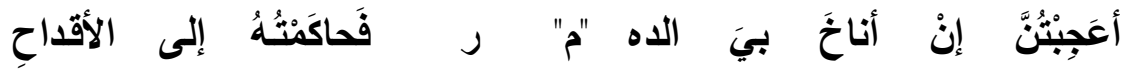

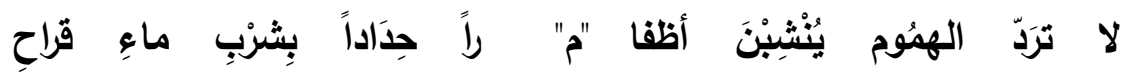

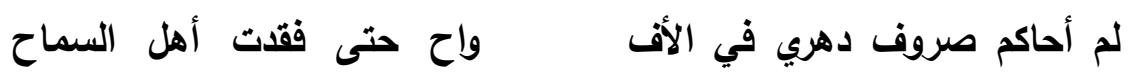

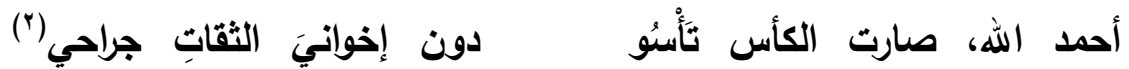

وقال في شروط السمر والمنادمة :

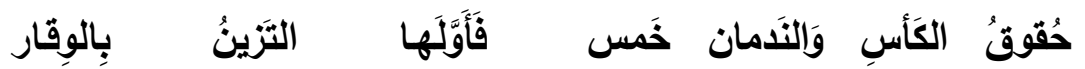

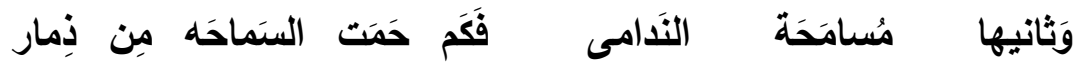

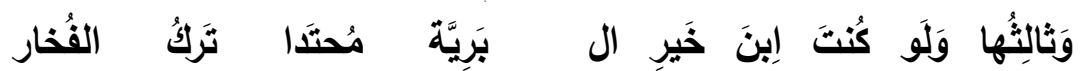

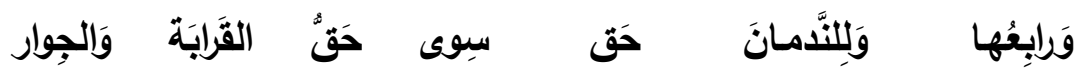

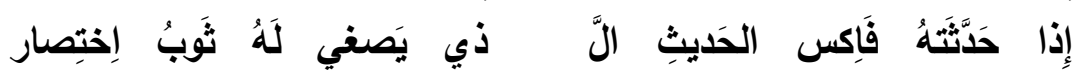

فَما حَثُّ النَبيذُ بِمِثِلِ حُسنِ الأَ

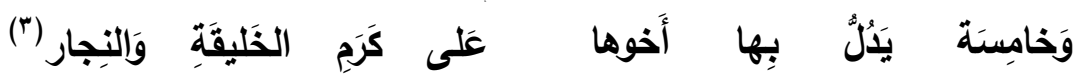

فهو يذكر في لطفٍ وظرف شروطًا خمسة للمنادمة وإلمسامرة، وهي : التعلي بالآداب ، والمسامحة في الثارب ، واجتناب المفاخرة بالأنساب ، والاختصار عند الرد على الجواب. 
قال الأصفهاني: "أخبرني عمي ، قال حدثي كوثرة " أخو العطوي ، قال : كان أخي عبد

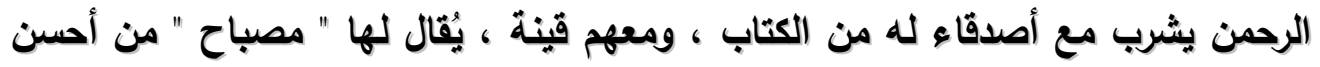

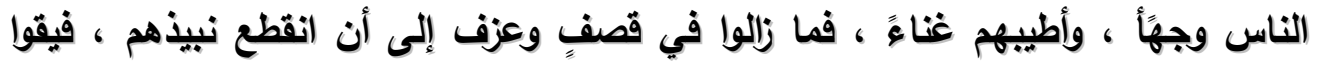

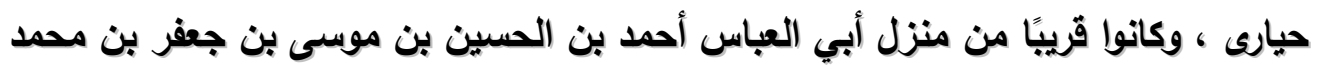

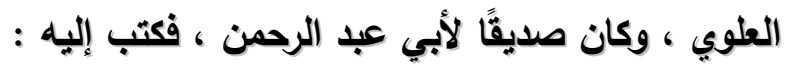

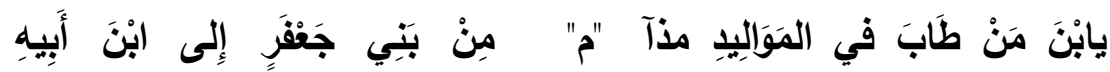

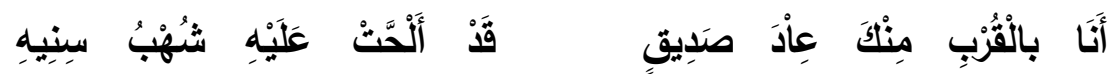

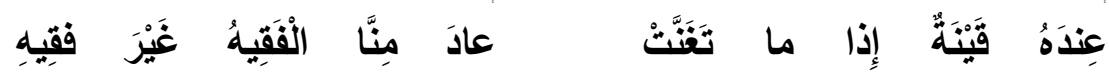

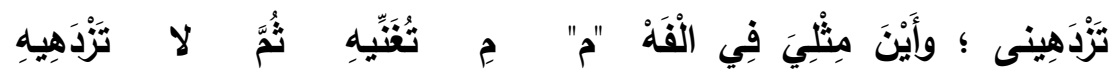
مَجْلِسُ كالرِيَاضِ حُسنْاً ، ولكنْ

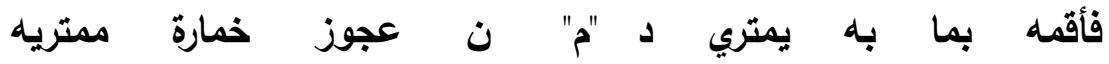

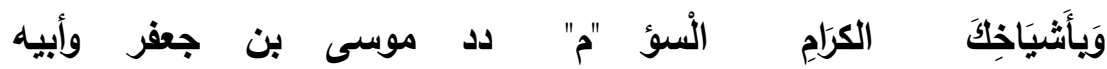

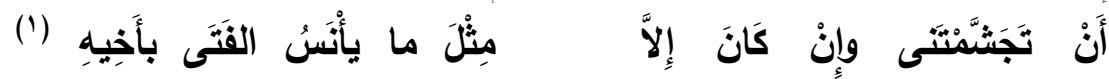

قال: فلما وصلت الرقعة إلى أبي العباس ، أرسل إليهم برواية شراب ، فلم يزالوا يشريون مجتمعين حتى نفذت . ولكن العجب في الأبيات السابقة أنه يدير مدحه على أنه من سلالة العترة النبوية المطهرة

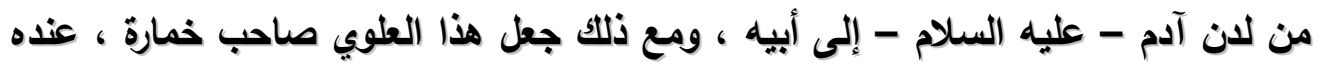

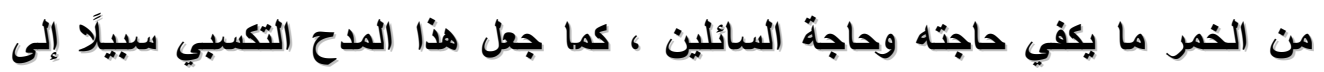
الحصول منه على دن من الخمر.

- الحكم والنصائح والتأملات : لقد نظم العطوي في شعره من هذا الغرض ، مقدمًا النصائح والصكم للوعظ ، وهذا ناتج من الخبرات والتجارب التي عاثها الثاعر في محنته وفرحته ، ثم يتحدث عن الناس ونفاقهم 
مُستويات الإيقاع في شعر العطوي "من الصوت إلى النص"

ي الحياة ، فقد ورد في (1 (1 مقطعة ) بنسبة 9 \% من مقطعات الديوان ، فمن نصائحه ووصاياه :

فأخلع لباسهم بالعلم والأدب

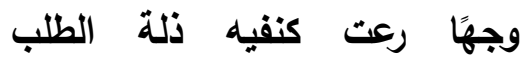

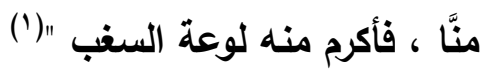

الحر يدنس بين الحرص والطلب

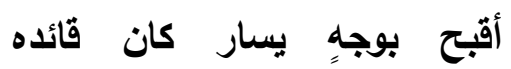

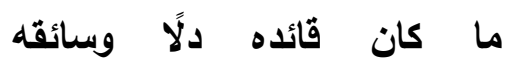
وقال في حسن المعاملة في السفر :

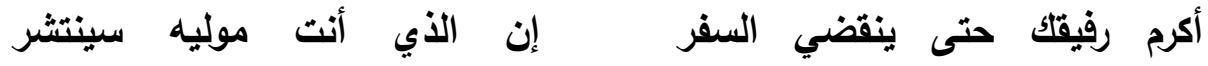

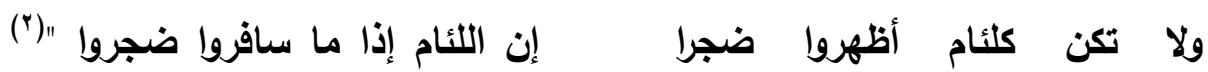

نتيجة الخبرات السابقة عند شاعرنا في السفر ، فيطالب بإكرام الرفقاء بعضهم لبعض في السفر ، وطيب المعاملة ؛ لأن السفر يفصح عن معادن الرجال ومقاديرهم في الكرم أو اللؤم

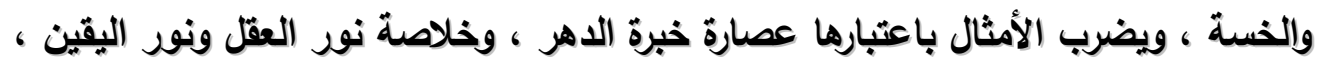
وطريق الاستقامة إلى المثل العليا. فمكن مليح أمثاله التي لم يسمع بأحسن منها المثل في بابها.

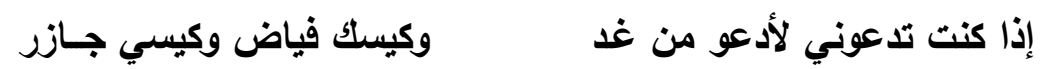

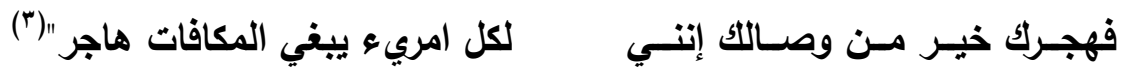
ومن أمثاله في تعظيم الناس لذي المال :

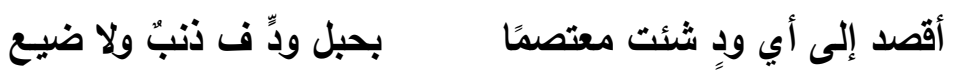

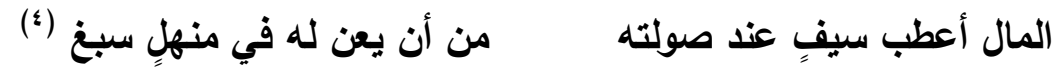

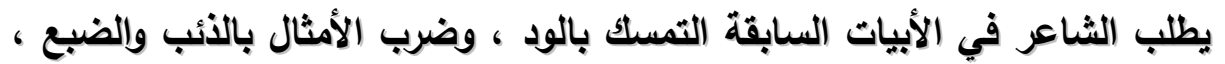

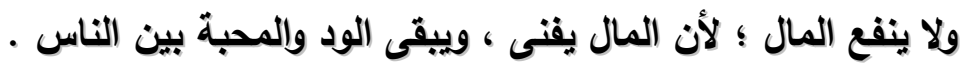
ثم ينظم العطوي في الحكم ، وهي عبارة عن نظرة حقيقية للحياة ، فمن هذه الحكم التي عبّر عنها الشاعر في قوله :

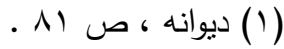

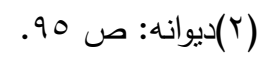

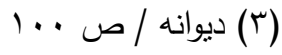

$$
\begin{aligned}
& \text { ديوانه ، } 10
\end{aligned}
$$


د. يوسف عباس علي حسين -

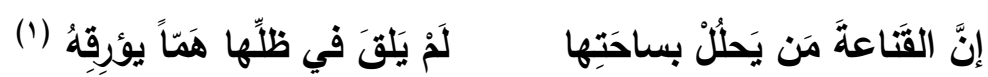

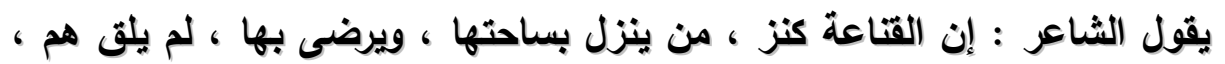

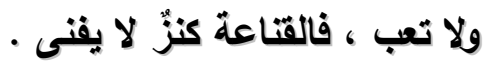

وقال في ذم الناس واتهامهم بالنفاق :

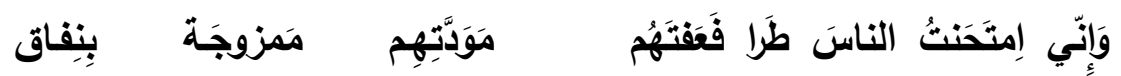

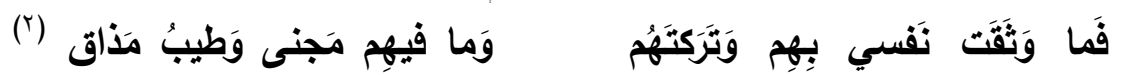

يقول الشاعر: إنه اختبر الناس جميعهم فكرهتهم ؛ لأنه وجد مودتهم فيها خداع وممزوجة بالنفاق .

وقال في كسب الرزق ، ونفي العار بالفقر:

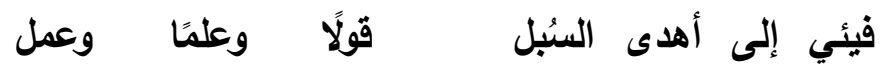

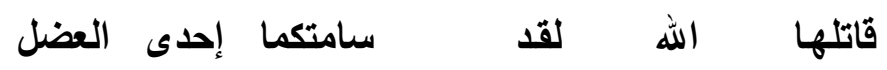

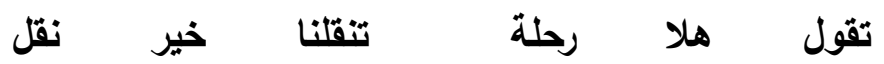

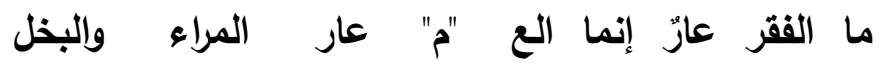

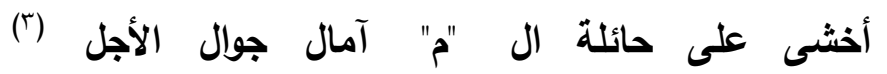

وقال في الأصدقاء والأخلاء :

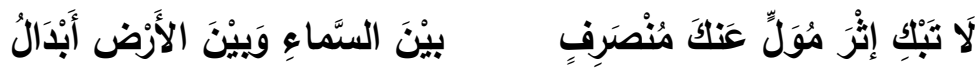

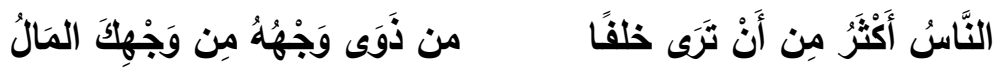

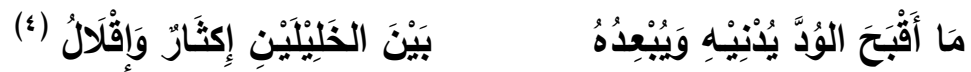

يقول : إذا مال عنك صديق وولّى وانصرف، فلا تحزن عليه ، ولا تبكِ مودته

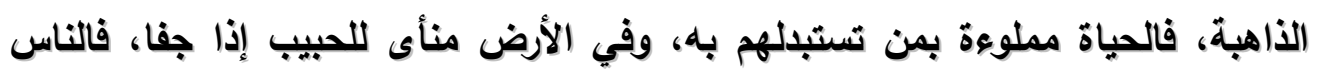

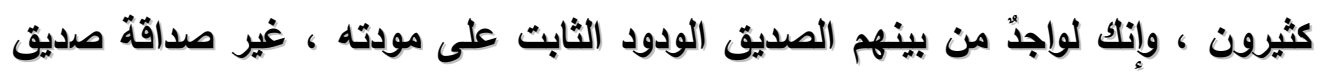



مُستويات الإيقاع في شعر العطوي "من الصوت إلى النص" يبطره المال ، فينحي وجهه عنك منصرفًا ، إن الوصال ليكون قبيحًا ، إذا كان يقربه المال

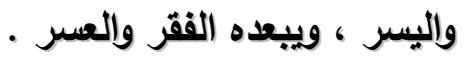

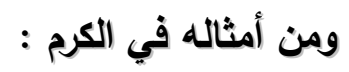
بالأصدقاء ففي وجدانها عدمُ

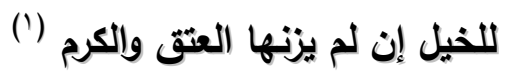
قلت وعزت عتاق الخيل واختلطت

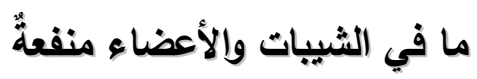

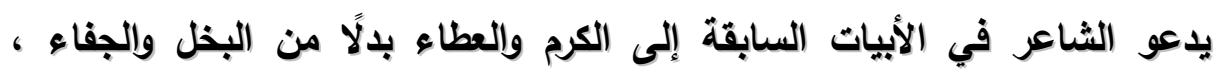

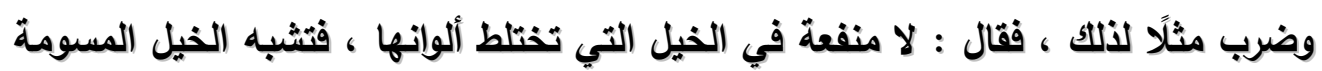
النجيبة ، إذا لم تكن مختارة من العتاق . وقال ينهى عن الإنعام والإحسان :

في الأمر بالبذل واذذكر ذلَّة العدم لَأَى المَمَاتِ عَلَيهِ أَكْرَمَ الكَرَمِ الأكر يبقى وتفنى لذَّة النَّعم

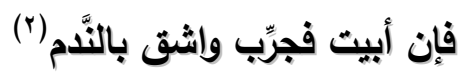

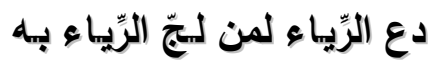

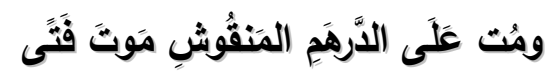

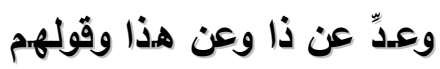

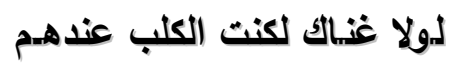

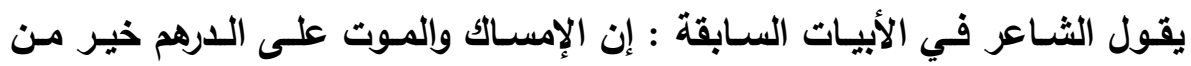
العطاء والصدقة ، ويقول : دع رياء المرائي ، وقل القائل : الأكر يبقى ، والبذل أولى ، فإِاذِا لم تعمل بنصيحتي ، فانفق مالك وجرب ملاحقة الندم .

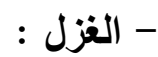

نظم العطوي في أشعاره في غرض الغزل ؛ حيث يبدو أن هذا اللون من الشعر كان

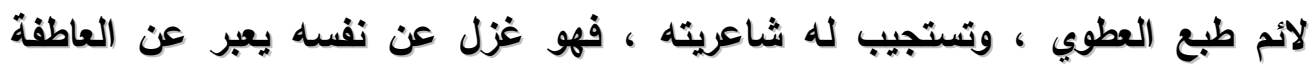

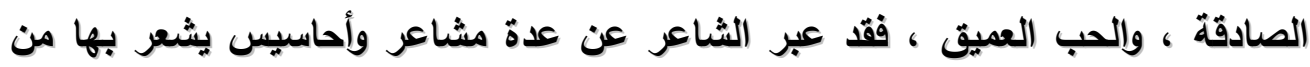

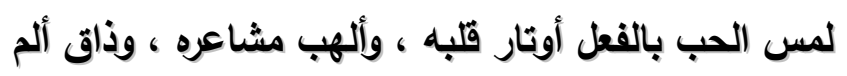
الجوى وحرقته ، فصور الحب في أسمى معانيه. 
د. يوسف عباس علي حسين

وقد تغزل الشاعر بالمؤنث والمذكر على السواء ، وغزله بنوعيه يموج بالرقة

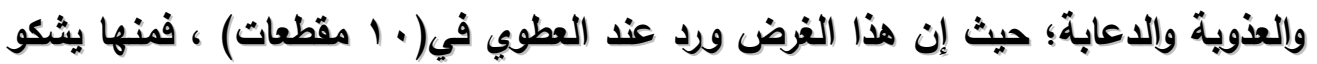
الرقباء والعواذل :

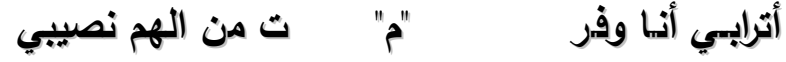

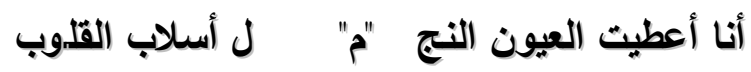

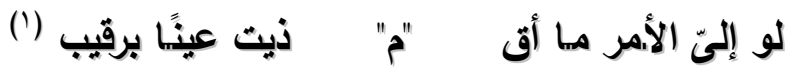

يشكو الثاعر في الأبيات السابقة ما تعرض له من الهم الذي أسقمه وأتعبه ، وجعل

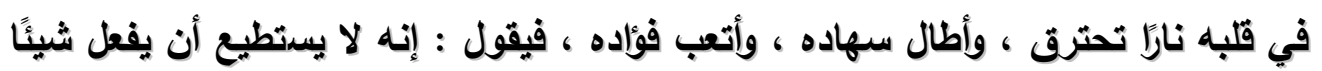
؛ لأن الأمر ليس بيده ، ولو كان الأمر بيده لقضى على العواذل واللوشاة .

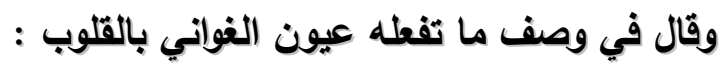

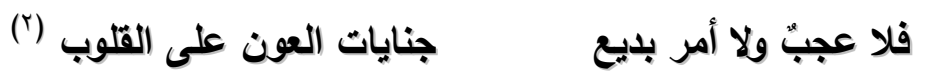

يحمل الشاعر في البيت السابق الذنب على العيون ، فما أضاف إليها جناياتها

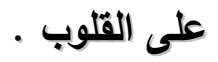

وتارةً يجيش عما في صدره من صورة مكشوفة مرذولة ، نتيجة غير مقبولة كتغزله بالغلمان ، وذلك في مثل قوله :

لسحر من مقلته السحر أحورٌ في أجفانه فتر فئه : ودئ

فحسنه مبتد عن منكر

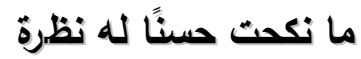
يقطر من وجنته الحمر يكاد إن أخجله مازج

وقد أى صورته عذر (") ما لفتى لم يصب من حبّه

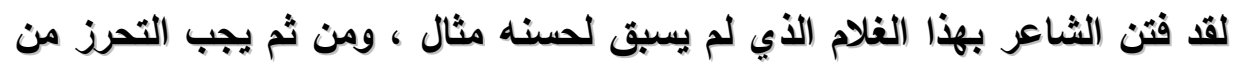

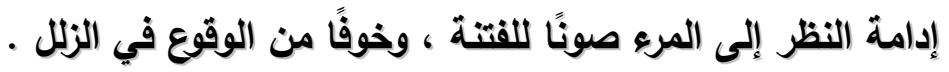
وقال يشكو وداع الأحبة ، ويصور مدى الحزن الذي انتابه :

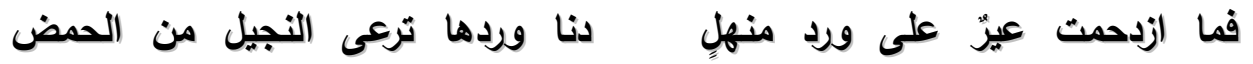

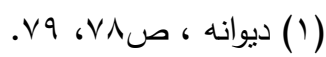

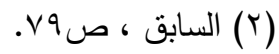

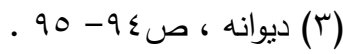


مُستويات الإيقاع في شعر العطوي "من الصوت إلى النص" ــ

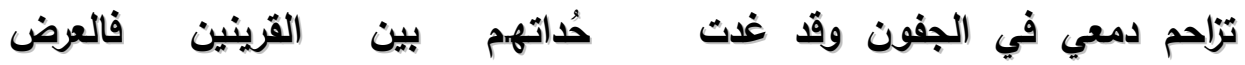

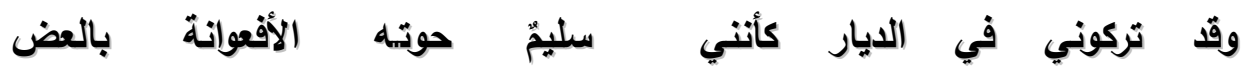
ولا أم أملاط أقامت فراخها على فتن في الضال ذي المنحنى الغض

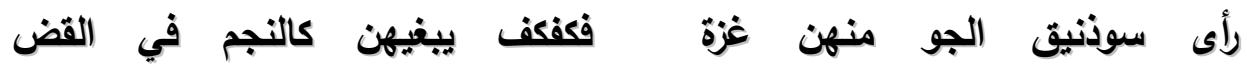
ولا أم خثفٍ أقبلت بعد فيقة لتمنحه من ضرعها صفوة المضل(')

وتقول لي : يا شيخ أنت مخادع

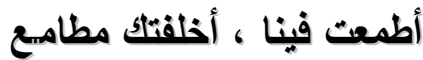

والثيب يذهبه الخضاب الناصع والقببح ليس لله دواءٌ نافيع

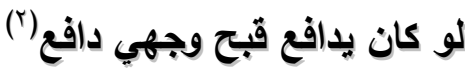

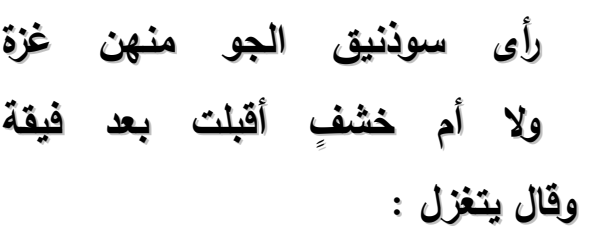

تاهت عليَّ بحسنها وجمالهيا

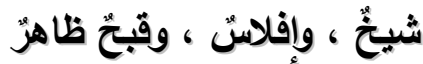
فأجبتها : الإفلاس يذهبه الغنى

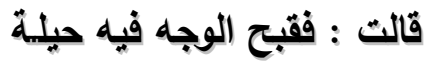
يا صدقها ما كان أوضح حجتي

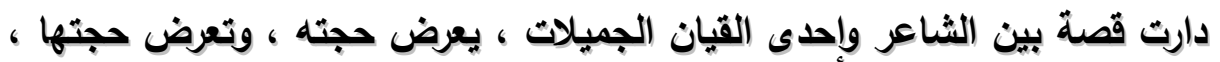

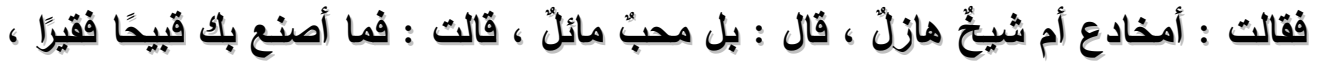

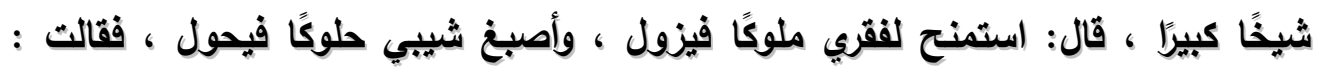

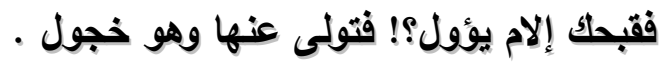
وقال يتغزل ، ويصف حبيبًا له غاب :

أقرأ على شبهك السلاما با قمرًا وافقق التمامـا كلاكما عزّ أن يُرامها (r) نأيت عنّي ويسان منّي

يصف الثاعر حبيبه الذي هجره بالجمال التام ، مشبهًا إياه بالقمر الذي غاب عنه

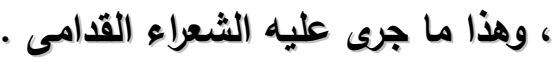
وقال في العاشث العفيف ، الطاهر النفس اللطيف : إن أكن عاثقًا ، فإنّي عفيف ال "م" لفظ وإلفرج عن ركوب الحرام

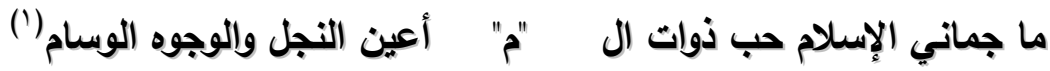




\section{شعر المناسبات :}

لقد نظم العطوي في أشعاره في هذا الغرض عن الأصدقاء ، مادحًا لهم ؛ حيث إن

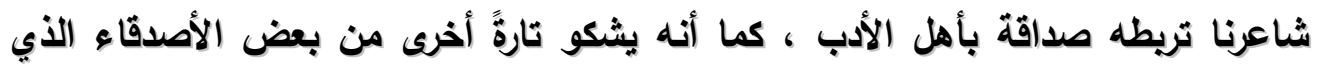
ساعت العلاقة بينه ويينهم ، فورد هذا اللون في ( 9 مقطعات) ، فقال في الحُجَّاب : حسن رأي في الحجاب لأبي بكرٍ خليلي وبني

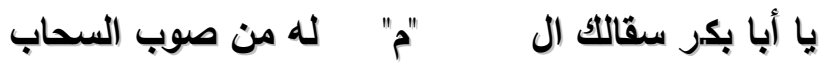

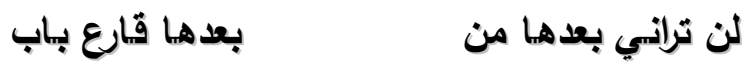

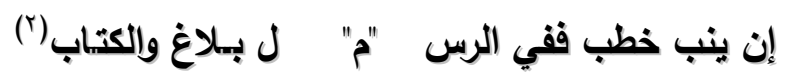

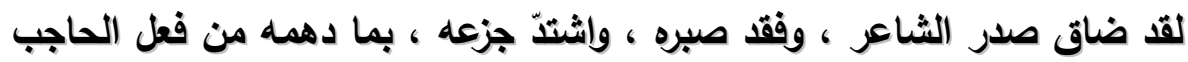

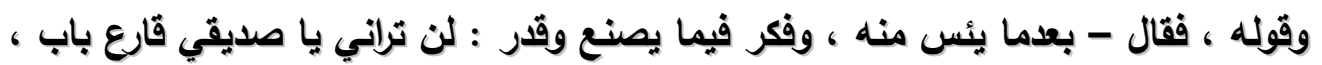

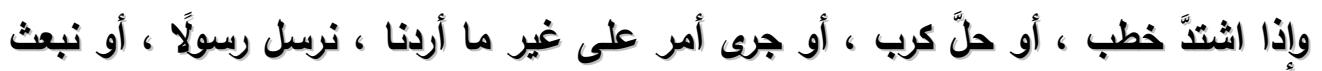
بكتاب . قال الثعالبي : لم أسمع في الاستزارة ألطف وأظرف وأخف من قول العطوي :

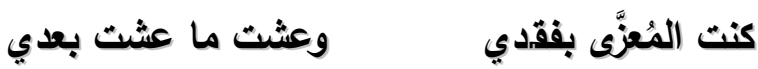

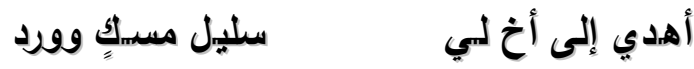

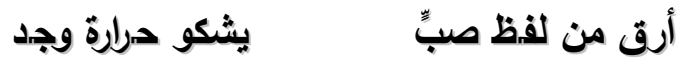

$$
\begin{aligned}
& \text { كأنسه إن تجنّى }
\end{aligned}
$$

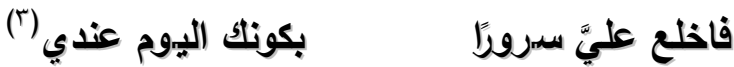

يبدو أن الثاعر كان محبَّا لمن يزوره ، أو يهدي إليه شينًا رفيقه ، وثدق الوعد

$$
\text { بلا غدرٍ أو خيانة . }
$$

كان العطوي صديقًا لعلي بن القاسم بن الحسين العلوي ، فولا لعي غلام ، فكتب

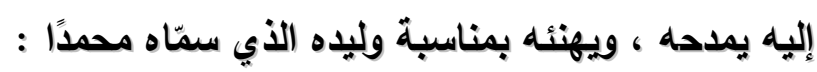

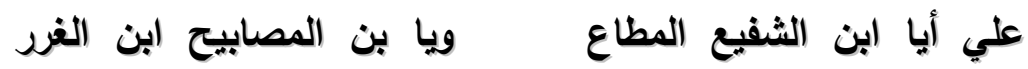

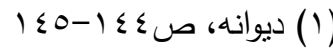

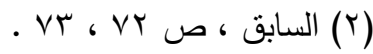

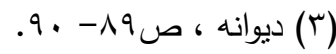


مُستويات الإيقاع في شعر العطوي "من الصوت إلى النص" ــ

ويا بن الثريعة وابن الكتا "م" ب بابن الرواية وابن الأثر

ويا بن المشاعر وإبن المقام وزمزم والركن وابن الحجر

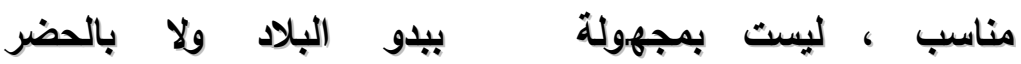

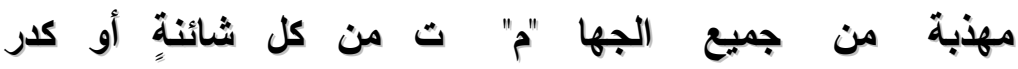

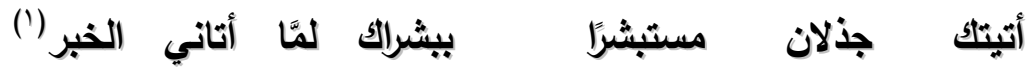

وليس فيها بحمد الله توفيزر

وقال في استقباح مطل قادرٍ :

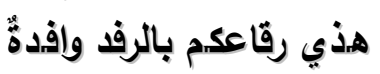

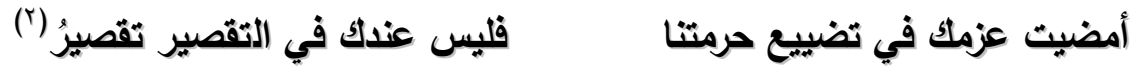

يقول الثاعر : إن عطايا المطل وأموال أصبحت تابعة لهواه ، لا بالاستحقاق ، ولا

بوضعها موضعها ، فلا حمد فيها ، ولا توفير ، وغير واضح المعنى بهذه الأبيات ، ريما

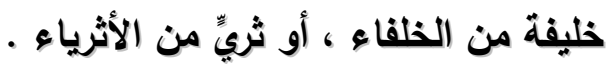

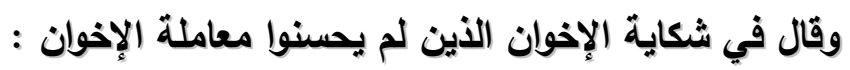

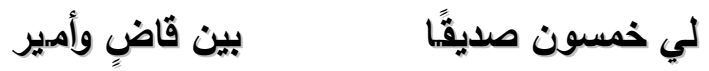

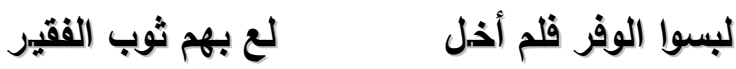

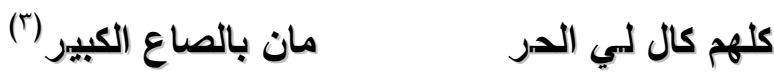

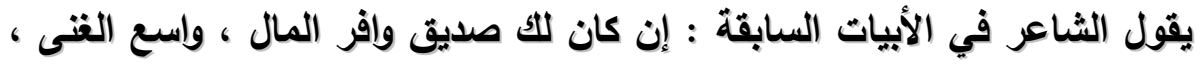

ولا يغير حال فقرك ، فهو رائق الظاهر ، خبيث الباطن ، وتبقى حزازات القلوب بينك ويينه لا تتغير لا تتبدل .

ومن أحسن ما قيل في ذم الإخوان ، وذم الاستكثار منهم ، قولهه :

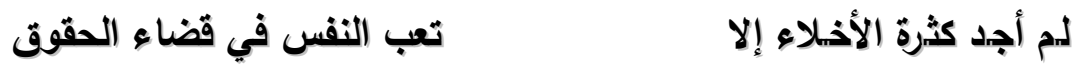

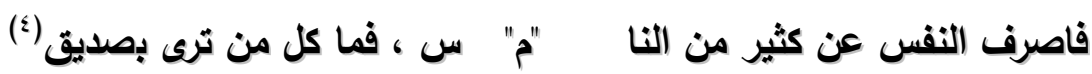
ومن نصائحه ووصاياه في الصداقة والصديق : فلست من التحير في مضيق

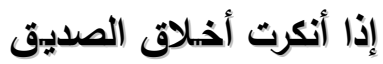

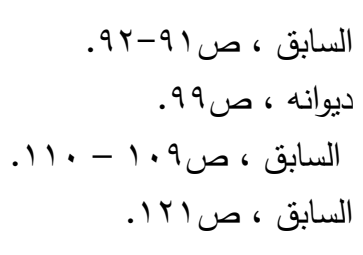


د. يوسف عباس علي حسين
فأسبغ فاجتتبه إلى طريق
طريقًا كنت تسلكيه سليمًا
فراجع من قطعت من الصديق (')
فإن قابلت يسري منه عسري

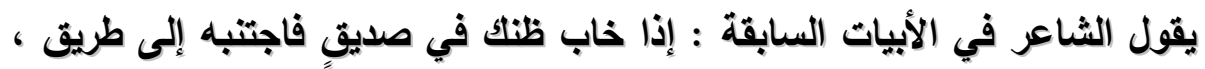

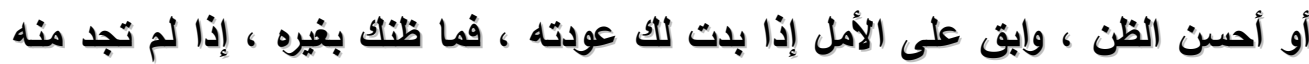

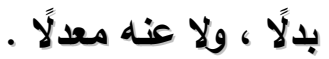
- شعر الثكوى

من بين الأغراض الثعرية التي طرقها العطوي : الثكوى ، فاستهل الثاعر

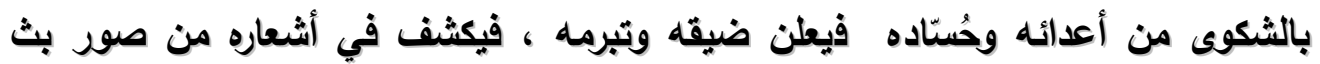

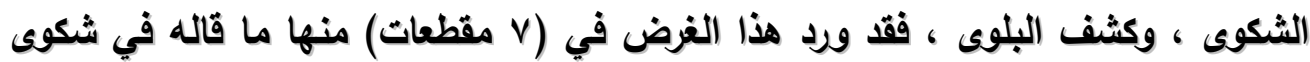
الزمان :

قال أبو حيّان : أنثدنا أبو بكر القومسي الفيلسوف ، وكان بحرًا عجاجًا ، وسراجًا

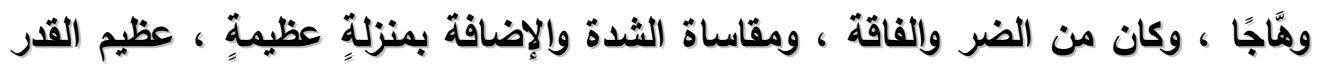

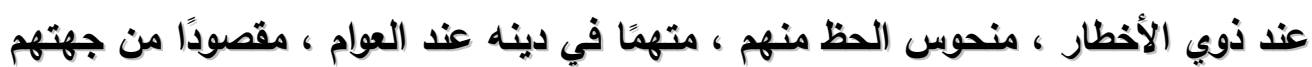

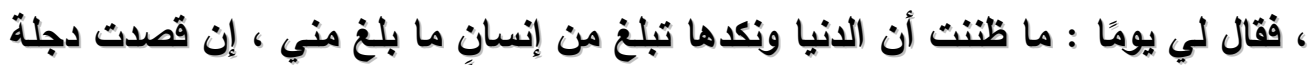

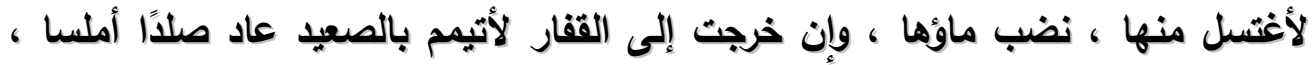

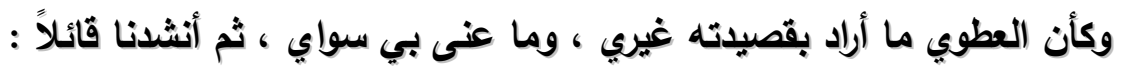

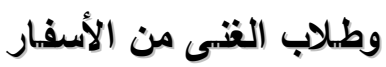
من رمساه الإله بالإقتسار ويوؤسٍ ومحنةٍ وصغنار هو في حيرةٍ وضنتك وإفتلاسٍ "م" د إلبيه مقاصيد الأحرلار يا أبا القاسم الذي أوضح الجيو

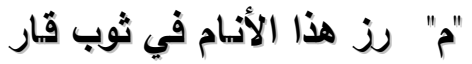
خذ حديثي فيان وجهي مذبا إنا ح نسيم الرياض غب القطار

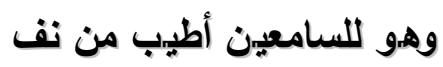
ر وجسمي عاد بغير دثار هجم البرد مسررعًا ويدي صف لفي ن إلى أن تهنكت أستّاري فتسترت منهله طبول التشياري "م" من صفار ما بينهم وكبار ونسجت الأطمار من ذروز قميصي

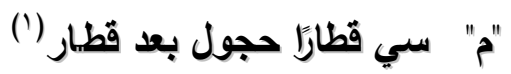
يتسياعون في ثيابي إلى لأ 
وقال يشكو فقره ودينه ، وما يعانيه عياله من برد الشتاء :

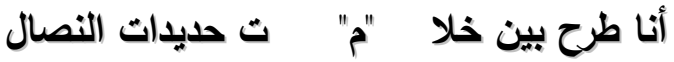

بين دينٍ وشتاعِ

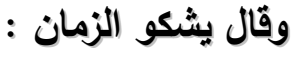

لما رأيت الدهر دهر الجاهل

ولم أر المحزون غير العاقل

شريت صرفًا من كروم بابل

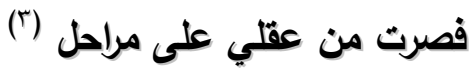

لأى الثاعر أن الحظ في الدنيا لمن لا عقول لهم، فتكلف إزالة عقله بالشراب، لعله مراجل

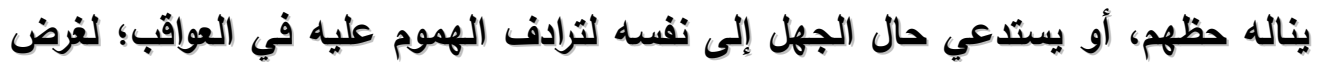

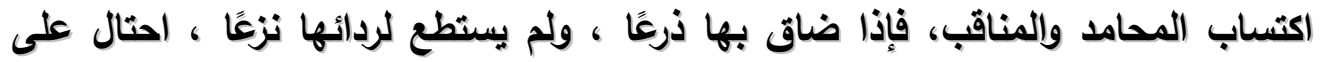

ذهابها بالشراب ، لينحل عنه عقال الهموم والأحزان بأيدي الأفراح .

وقال يشكو الحياة، ويتحسر على حالها النفسية المعكوسة التي تحرم جامع العلم، وتعطي جامع المال :

يا أيها الجامع علمًا جمَّا

امض إلى الحرفة قدمًا قدمًا

حرمت وفرا ورزقت فهمًا

والأي أجزل منه القسما

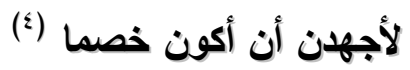

وعن زوال الندى في العرب والعجم أم التواصل في الدنيا على عقم زيم قد كان يرعى من الأخـلاق والأمم
وقال يشكو الزمان :

سيألت عن سبب الإقتار والعدم

نودي:هوت أنجم الإفضال وإشتملت أنعي إليك مواسياة الصديق لودي الصنا

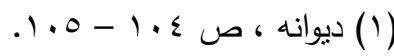

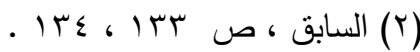

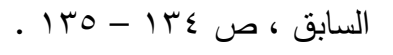

$$
\begin{aligned}
& \text { ديوانه ، ص }
\end{aligned}
$$


لم لم يبق منهن إلا دارس العلم

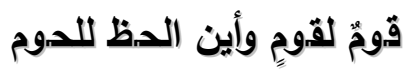

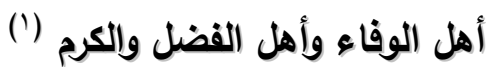

أنعي إليك خـلال الفضل قاطبةً

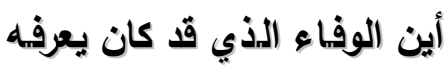

أين الجميل الذي قد كان ملتبسًا

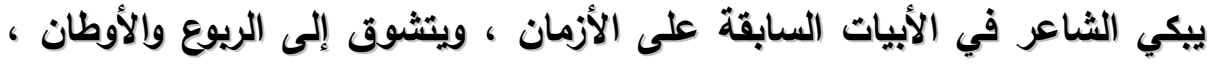

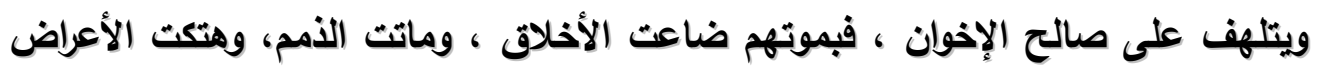

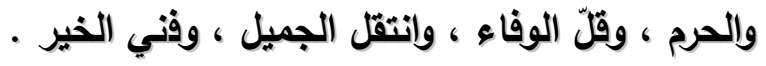
وقال يشكو الزمان وسوء حاله الذي وصل ولئ إليه :
أيا من قد ظفرت فلا تهنيا
أقول وحالتي تزداد نقصًا
على طلب المعيشة لا تغني
وللانفس التي تنقض حزنًا
ولا تعصي الإله ولا تغني
سبأتيك المقدر فأعلمهيه

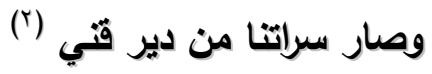
فهذا الدهر صيرنا رذالاً

يشكو الشاعر حاله التي تتناقض يومًا بعد يوم ، ويندب معيشته التي لم يستطع

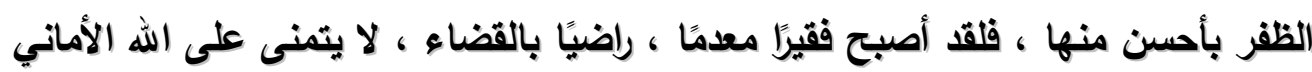

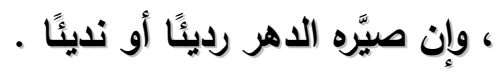

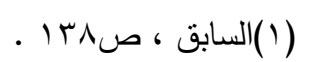

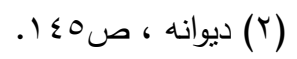


هو تعديد محاسن الميت ، والأسى عليه ، والرقة له ، وخشوع النفس (')"

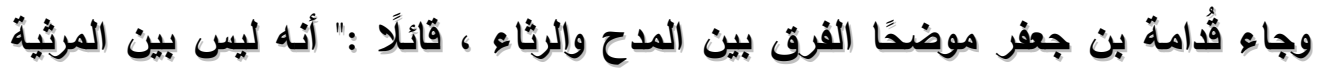

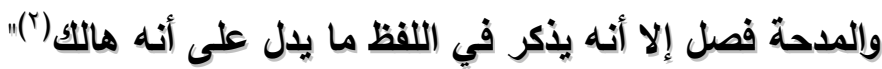

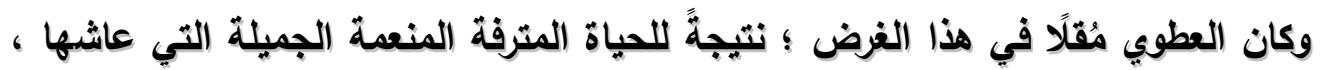

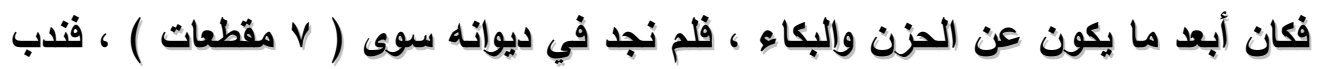
القريب ، وأبن البعيد ، ويكى المدن والدول الزائلة ، فقال يرثي من رثى ذائ ذاكرًا إحدى خصاله:

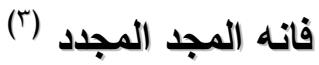
فلقد كفن في أك أك ون

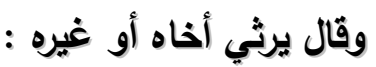
حنطته با نصر بالكافور وزفقته للمنزل المهجور

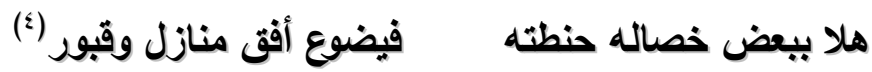

يقول الشاعر : إن عمل خلطة من مسك وعنبر وكافور ، ووضعه على جسمه

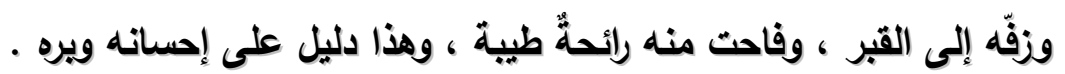

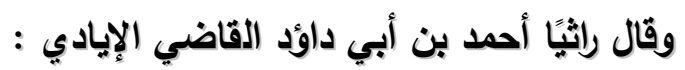
ولكنه أصب قومِ تقصف وليس صرير النعش ما تسمعونه

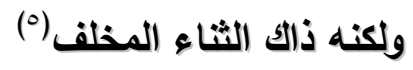
وليس نسيم المسك ما تجدونه يقول الشاعر : إن محاسن أحمد بن أبي داؤد كثيرة ، ومناقبه شهيرة ، سارت بهاء داءيه

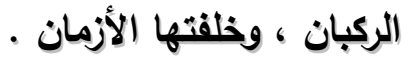
وقال يرثي أخاه :

فما رقأت منه الدموع الهواطل وهيض جناحاه وحد الأنامل
لقد باكرته بالميلام عواذلي أيقني جميل الصبر منه هدركته باكن عادئ

(1) ابن الأثير : جوهر الكنز " تلخيص كنز البراعة في أدوات ذوب البراعة " ، تحقيق : محمد زغلول سلام -

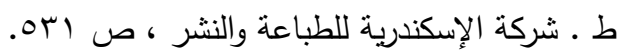

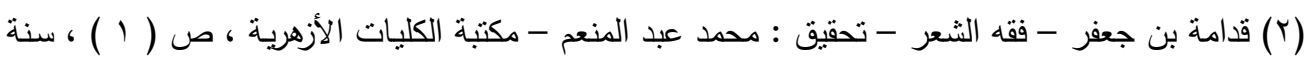
(19AV

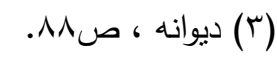

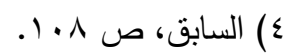

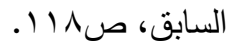


د. يوسف عباس علي حسين

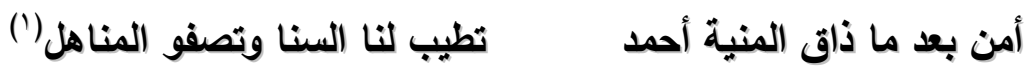
لقد مات أخوه ، وحزن حزنًا شديدًا ، وتضاعف أساه على الأيام ، ويموت أخيه تكدرت المناهل والمشارب الرائقة ، وضاقت عليه الدنيا الفائقة . وقال يرثي :

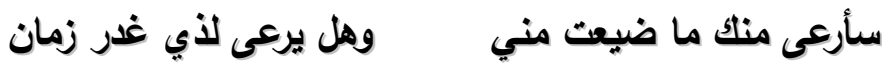

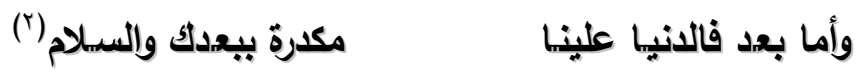

وغير خافٍ لاينا أن العطوي لم يكن يعنيه هذا الضرب من الشعر كعنايته

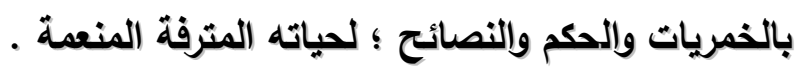

العتاب :

يعد هذا الغرض من الفنون التي سيطرت على عواطف الثاعر ، وأظهرت ما

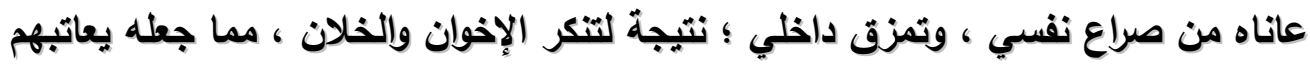

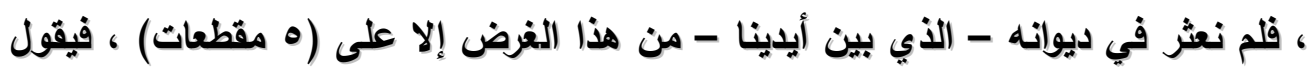
العطوي معاتبًا نفسه :

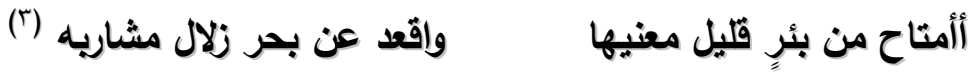

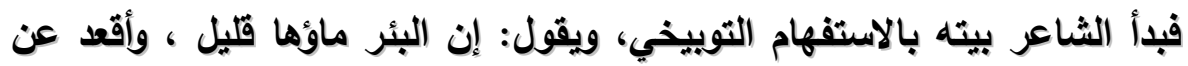
بحر مياهه عذبة . وقال يعاتب الخليفة المعتضد عندما أقام بسنجار ، وترك بغداد :

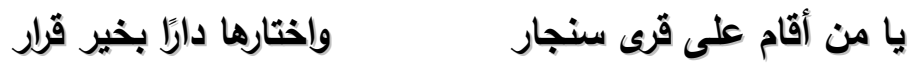

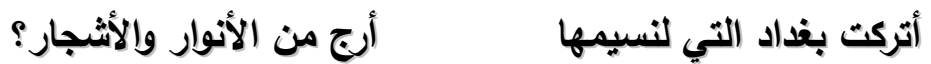

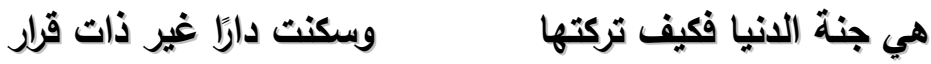
أوليس فيها ألف ألف خريدة

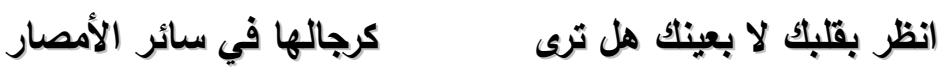

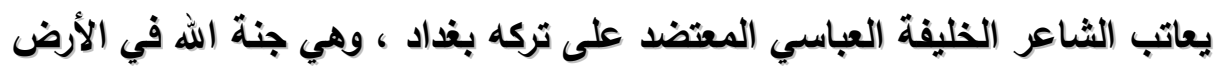

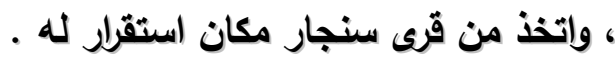

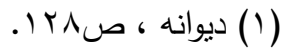

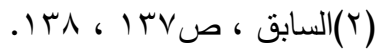

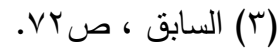


وقال في حفظ السر وذم إذاعته :

شدوًا وحصرً أصر القوم أو ترعوا

حبل الصفاء كفيب ليس يطلع

تنبو المعاول عنها ليس تنصدع) (')
عندي لهم أنني أرعى أواصرهم

وإن أسرارهم عندي وإن قطعوا

يأوي إلى صخرة من ململمية

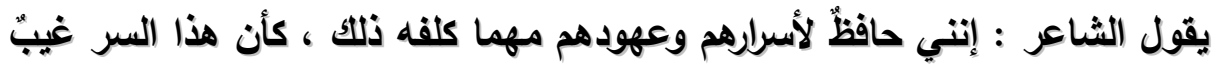

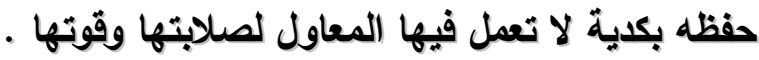
وقال يعاتب أبا الحسن على عدم نوالهه مع حسن حاله :

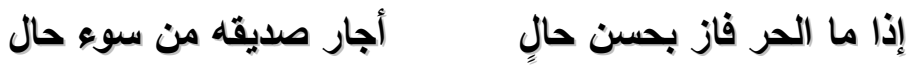

لـه الإفضال من قبل السؤال

إذا أثرة رأى حقّا عليه

يحب الميال إلا للتبوال

لعمرك ما رأيت فتئً كريما

أحاول من مقالي أو فعالي

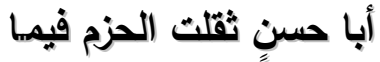

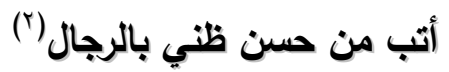

لق كذبت ظنوني فيك إن لم

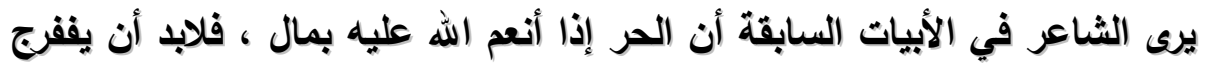

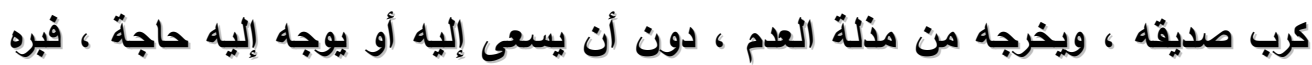

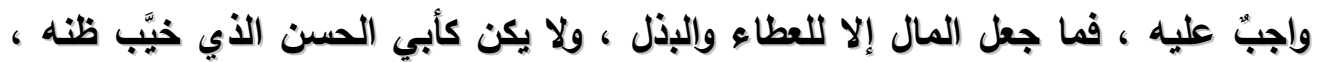

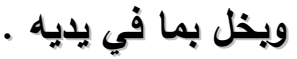

: الفخر

اهتم الشعراء منذ العصر الجاهلي بمفاخرهم ، ومفاخر أقوامهم وقبائلهم ، من كرٍ

وشجاعةٍ ومروعةٍ وعفةٍ

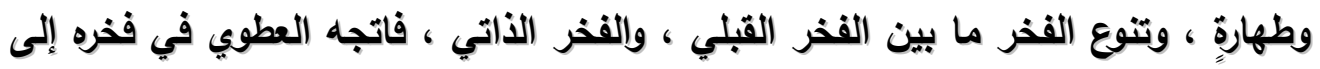

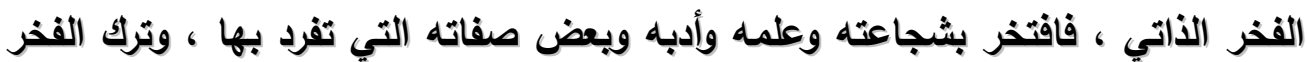

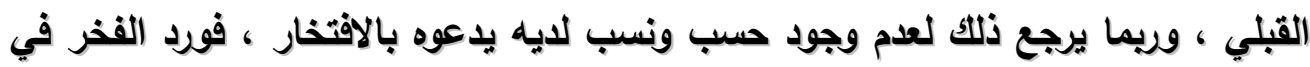
ديوانه في ( • مقطعات ) ، منها :

وأضرب هامة الأسدد أهياب الريبم أرمقهيه 
د. يوسف عباس علي حسين

ويجزرحني بمقلتهِهِ

يقول الثاعر : إنه رقيق الوجه من شدة الحياء ، مع أنه شجاع عند الحرب ،

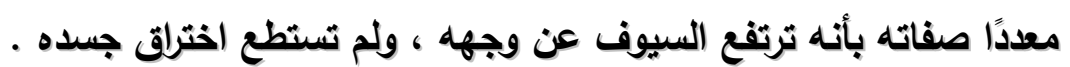

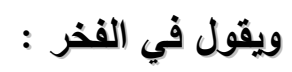

ومن شيمي التجاوز عن صديقٍ أطاف بغيةٍ ، أو قال هجرا

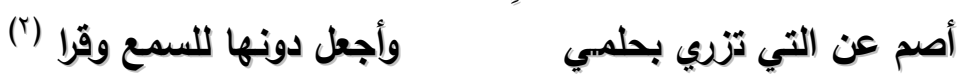

يذكر لنا الشـاعر شمائله التي يمتاز بها ، وهي التجاوز عن الصديق الذي يقر دئر

بذنبه ، والصفح عمّن أساء إليه .

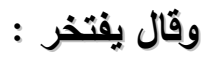

بر فخير العلقتين في ياكك

يا نفسي دومي على العبادة والص

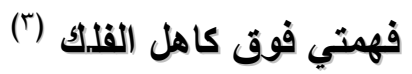

إنبي وإن كنت لابستًا سملثا

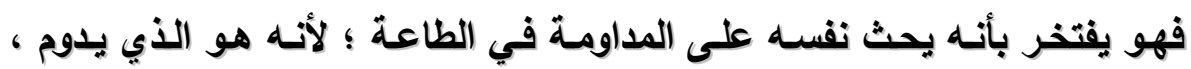

وعنده همة تفوق همم الملوك .

: المداح

يُعدُ هذا الغرض من أحبّ الأغراض الثـعرية التي أحبها الإنسـان ؛ لأن الإنسـان

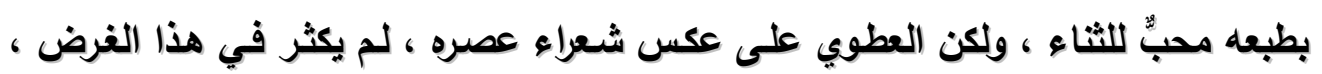

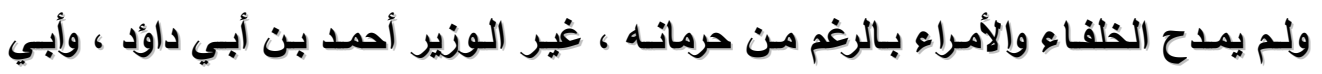

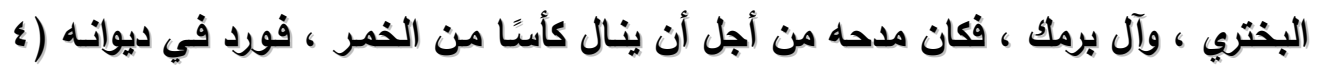

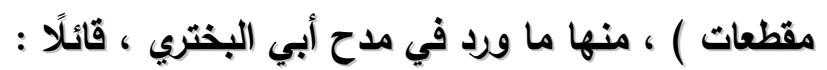

تبعق في الأرض أسعده السكب

كما ضرَّ البلر ينبحسه الكلب الارض اسعده

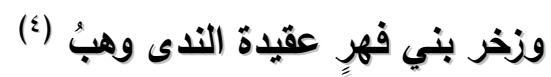

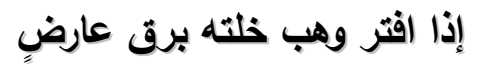
وما ضرَّ وهبًا ذم من خالف الملا

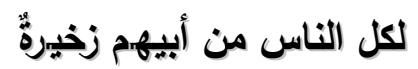

$$
\begin{aligned}
& \text { (1) السابق ، ص991. } \\
& \text { (Y) ديوانه ، صع (Y) }
\end{aligned}
$$

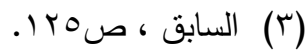

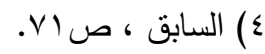


يمدح الشـاعر ممدوحسه بـالجود واللــاء ، وكـان فقيهًا ، سـريًا ، عالمًا بالأخبـار

والأنساب .

وقال في مدح محمد بن عمران بن موسى بن خالد بن برمك :

فعل الكرام فعلموا الناسيا

لم يهذموا لبنائهم أساسيا

جعوا لها طول البقاء لباسا

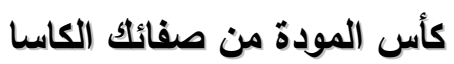

أن القطيعة توحش الإيناسيا (')
إن البرامكة الكرام تعلموا

كانوا إذا غرسوا سقوا وإذا بذوا

وإذا هم صنعوا الصنائع في الورى

فعلام تسقيني وأنت سقيتني

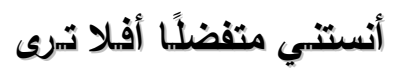

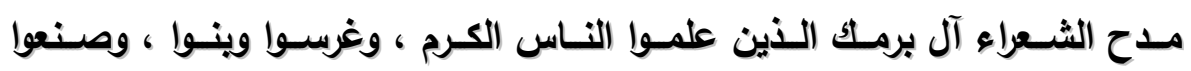

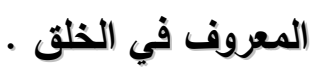

وقال يمدح أبي العباس أحمد بن الحسن بن موسى بن جعفر بن محمد العلوي :

دم جهرًا إلى الحسين أبيسه

قد ألحت عليه شهب سنيبة

عاد منا الفقيه غير فيه

"م" م تغنيه ثم لا تززدهيه؟

ليس قطب السرور واللاهو فيه تقديه

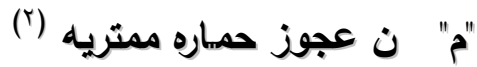

يـا من طاب في المواليد.

أنا بالقرب منك عند كريهم

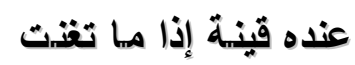

تزدهيني،وأين مثلي في الفه

مجلس كالرياض حسنًا ولكن

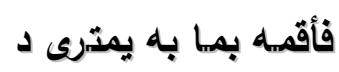

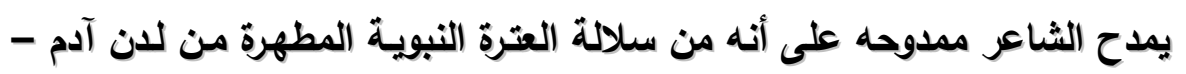

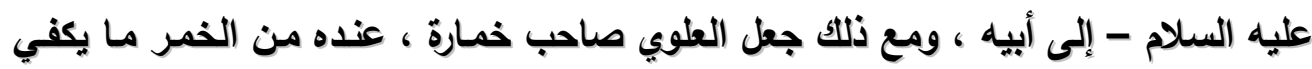

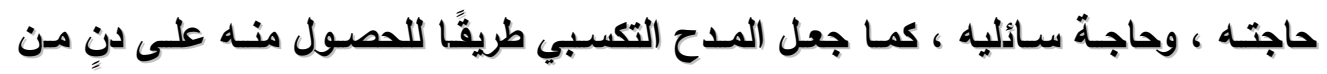

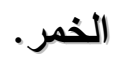


دعا الثاعر نفسه مثل غيره من الثـراء إلى الانصراف عن الدنيا ومتاعها الزائل ،

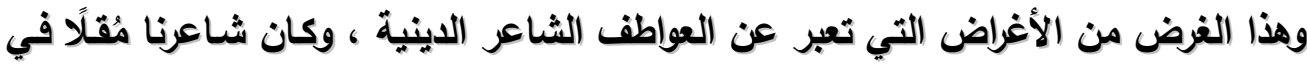
هذا الغرض ؛ حيث ورد في ديوانه ( ؛ مقطعات ) . قال في انتظار اليسر بعد العسر :

يبلى ويصبر الأثبياء تنتهج جاءتكلك تضحك عن ظلمائها السرج منسه المطاميع فالمعزى به يلج

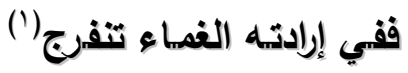
مستشعر الصبر مقرونًا به الفرج حتّى إذا بلغت مقدور غايتها فاصبر ودم واقرع الباب الذي طلعت يقدر الله فارجُ الله وارض بـابه لهابه يقول الشاعر في الأبيات السابقة : لئه إن الذي يتحلى بالصبر في الثـائد ، ويداوم على قرع بـاب الله تعالى بالدعاء ، ويرضسى بقضـائه وإرادتـه ، ينتظر الفرج من همومـهـ جزاءً على صبره ، فمـا من عسرِ إلا وأتبعه اليسر. وقال في الاقتصاد في طلب الرزق :

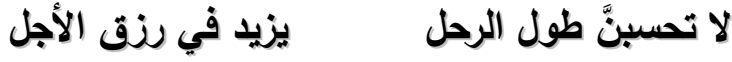

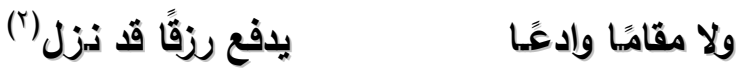

يحض الثـاعر في البيتين السـابقين على التأني في طلب الرزق والكسب ، فـلا

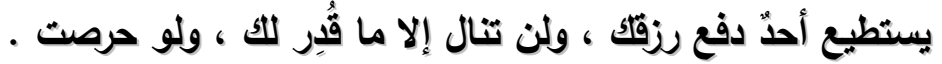

وهو رهن بأقرب الآجال كيف صول الآجال بالآمال "م" و ولم يغترر بار الزوال حركات الإدبار والإقبال لم يكن غير عاثر بمقال ومن زهدياته :

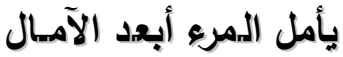
لو رأى المرء رأي عينيه يومًا لتناهى وأقصد الخطو في اليه نحن نلهو ، ونحن يُحصى علينا فإذا ساعة المنية حميت 
مُستويات الإيقاع في شعر العطوي "من الصوت إلى النص"

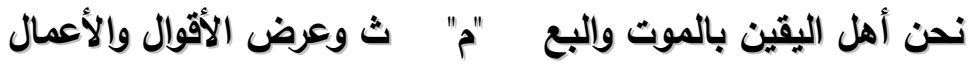

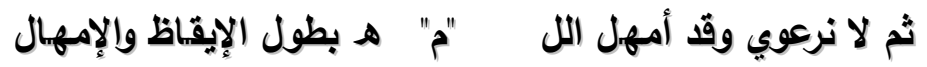

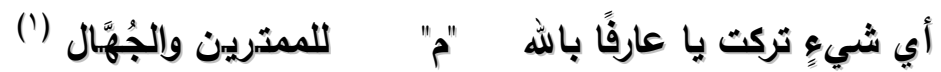

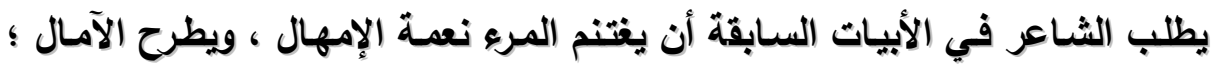

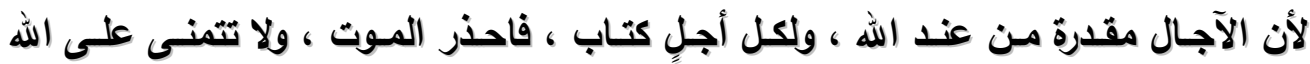

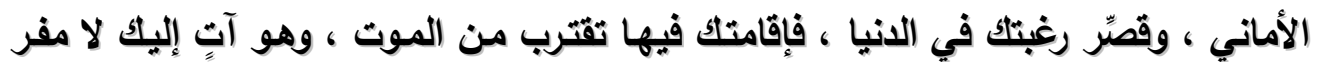

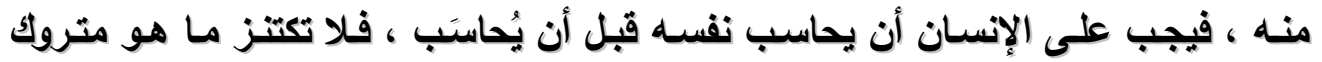
لغيرك ، وأنت محاسبّ عليه ، فالكل عند الله سواء ، لا يفرق إلا بصالح الأعمال . ويقول الثاعر شاكيًّا من الزمان :

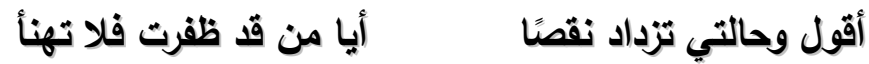

وللنفس التي تنقض حزنًا على طلب المعيشة لا تغني

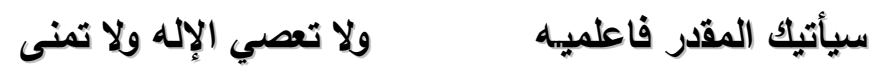

فهذا الدهر صبرنا رذالاً

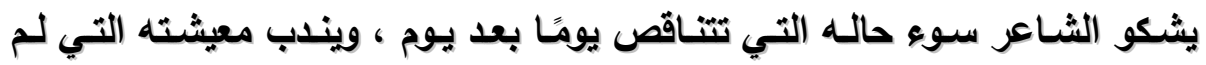

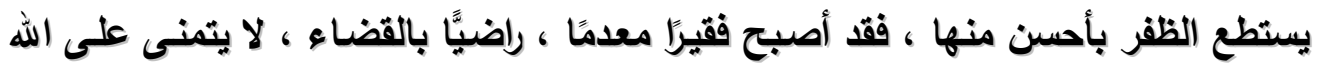

- الأماني

قال في القناعة والاستعطاف :

عندي من الناس من أنباعٍ وتجريةٍ

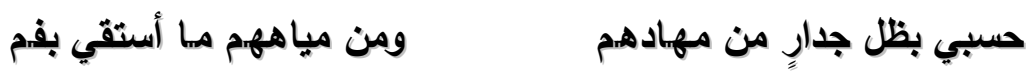

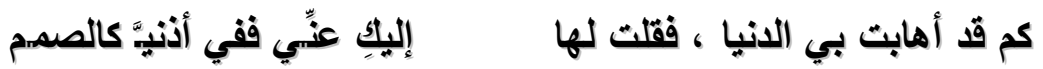

وصون وجهي عن لا لا وعن نعم

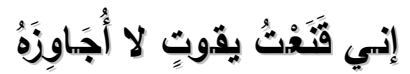

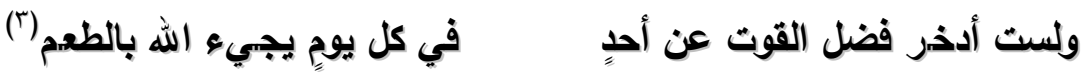

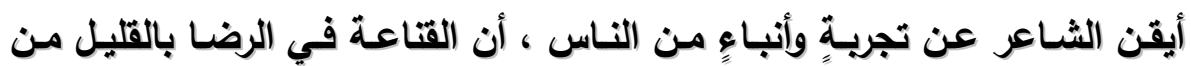

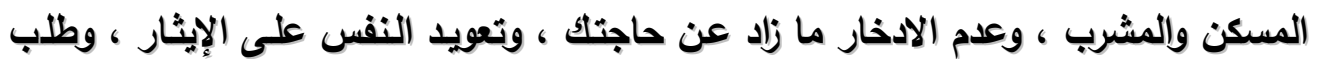

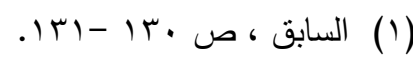

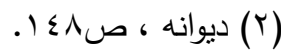

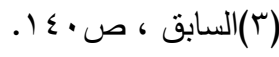


د. - يوسف عباس علي حسين

الغني في القناعة ، وحفظ ماء الوجه ، فمالك سوف تستو فيه فلا غنى لمن لا قناعة لـه ، واعلم بأن رزقك لا يأخذه غيرك ، وقوتيك آتيك لا محالة.

الإهجاء:

يُعدّ أحد الأغراض الشعرية التي نظم فيها العطوي لكنهـ كان مقلًا ، فلم تتجاوز المقطعات في ديوانـه ( r مقطعات ) ، وكـان هجاؤه لا يتخذ صورة حسادة بـل كان صورة

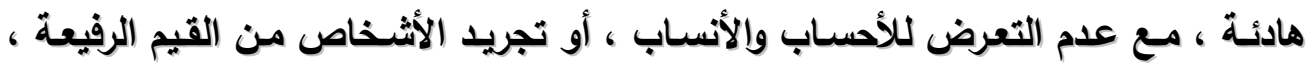
منها :

يحسبوه من جملة الكُتَّبِ

قل مل لمن فضف الدواة لكيما

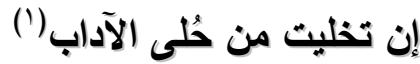

ليس خليَّ الدواة ينفع شينًا

يقول الشاعر : ليس كل من مـارس الكتابة أصبح كاتبًا ، ومن تخلت عنسه الآداب

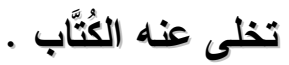

ويقول الثـاعر : استأذنت إبراهيم بن المدبر فحجبني أذنـه ، فأخذت ورقةً كتبت إليه أهجو صاحبه :

إن أنت لم ترسل وجئت فلم أصل ملأت بعذرٍ منك سمع لبيب قصدتك مشتاقًا فلم أزَ حاجبًا

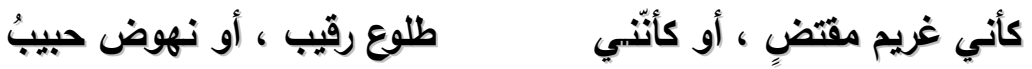

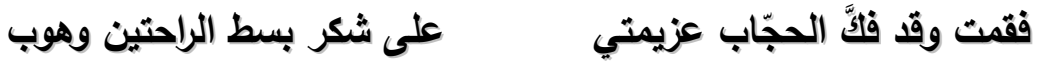

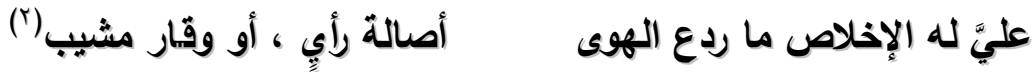

الوصف:

اهتم الثعراء منذ العصر الجاهلي بوصف الطبيعة ، وما اشتملت عليه من صخور

ورمال وجبال ، وفتن بها الثـعراء فوصفوا مـا بها حدائق وحقول ، ولكنّ العطوي خالف

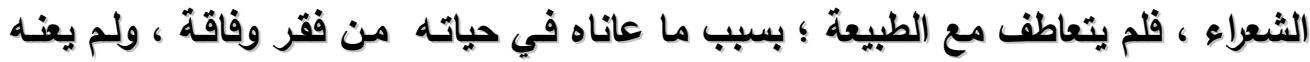

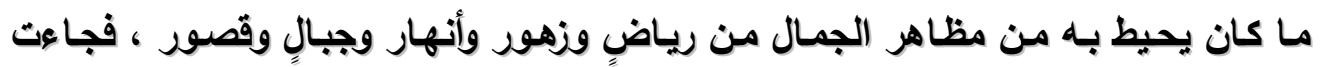


أوصـافه قليلـة في ديوانـه ، فلم تتعد ( ب مقطوعـات) ، منها وصف ليلـة مظلمـة سـوادها

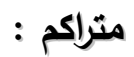

تحمل في الجوّ منه رايات كمينُ جيشٍ منه الدجنات

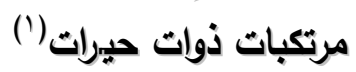

وربَّ ليلٍ باتت عساكره

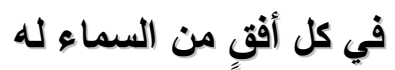

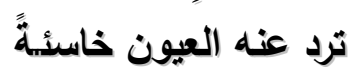

وقال يصف وجه امرأة ، وريقها ، وثغرها :

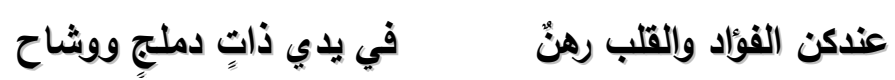

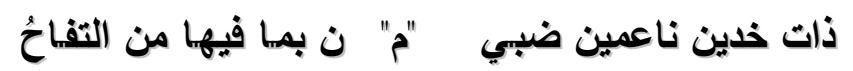

من مدام وروضة من أقماح

وثثايا رقيقةٍ تغدير

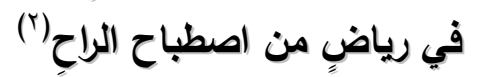

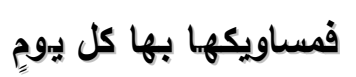

الثبيب :

لم يهتم العطوي بهذا الغرض ؛ ولذلك لم يزد في ديوانه عن ( مقطوعةٍ وإحدٍ) في قوله :

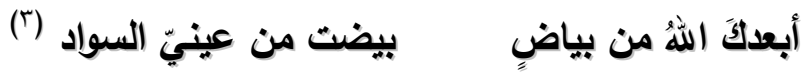

يذم الشاعر الشيب ؛ حيث يقول : إن بياض الشيب ليس فيه سرور ، فلقد أصابه بالعمى ، ويؤذن بحلول الأجل ، وإنقطاع الأمل.

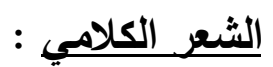

لقد تلخل العطوي مع معاصريه في ملاحم كلامية ، فنظم في هذا الغرض ملحمـةً

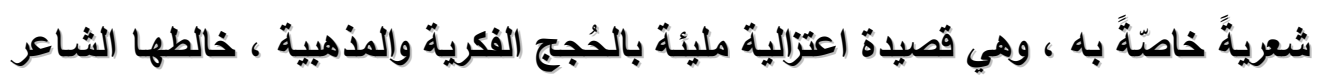

بهجاء خصمه ، فقال في الرد على هشام بن الدكم البذدادي القائل بالتجسيم والتشبيه :

عن صفات الأعراضِ والأجسامِ لحظات الأبصار والأوهام

قال في الله مثل قولِ هِشام عاملًا من كبائر الآثنامٍ
جلَّ ربٌّ الأعراضِ والأجسامٍ

جلَّ ربِّي عن كل ما اكتنفته

بريء ربي من هشامٍ وممن

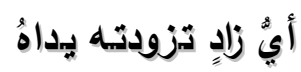

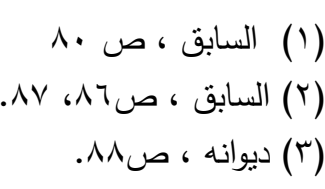


د. يوسف عباس علي حسين

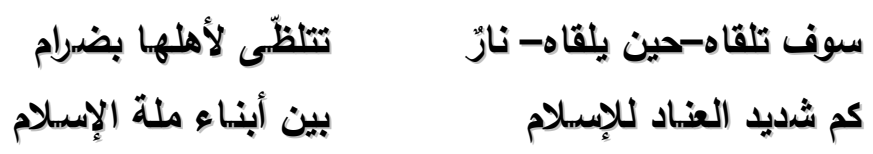

قة من ككل حرمة وزمام

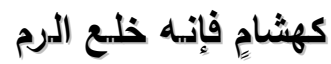

خير مسترشدٍ وخير إمـامِ

قّل لمن قال قوّله ورآه

في مساعيه عابد الأصنامٍ

لم أنكرت أن يكون مصيبًا

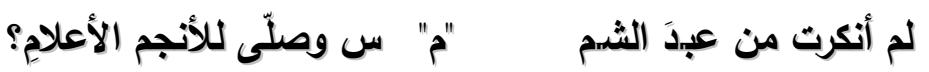

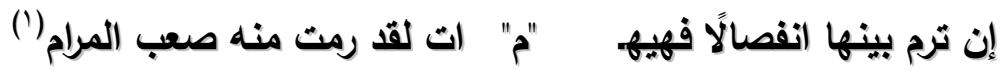

في الأبيات السابقة يقول الشاعر : نزَّه الله تعالى عن التشبيه والتجسيم الذي قال فئه

به هشام ، أو من قال بقولهـ ، ثم يتهم ويستهزئ بـه ، فيقول : إذا كان الأمر كما تقول

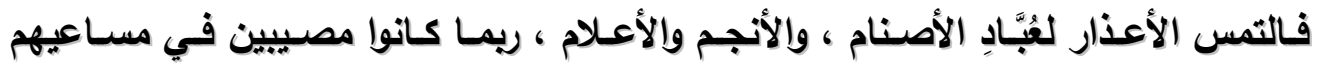

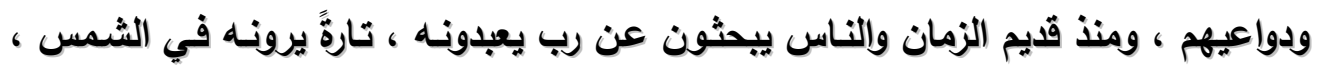
وتارةً في النجوم ، ودليلّ على ذلك خير من لقاء إبراهيم - عليه السلام - مع أبيه آزر. 

مُستويات الإيقاع في شعر العطوي "من الصوت إلى النص" الفصل الثاني مُسنويات الإيقاع عند العطوي

موسيقى اللغة عند العطوي :

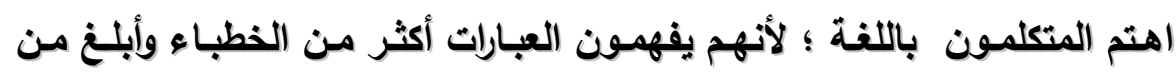

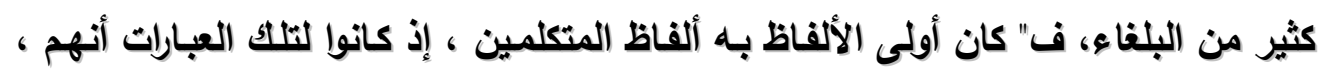

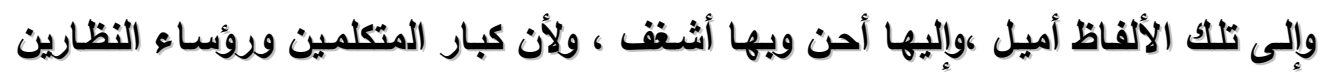

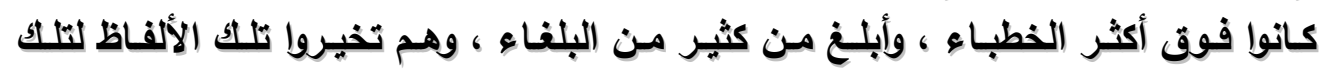

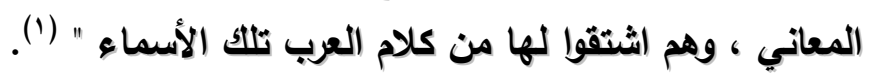

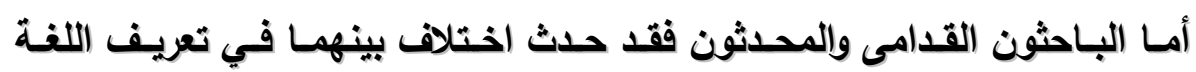

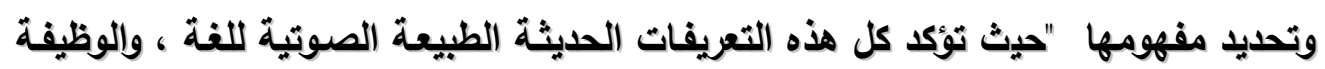

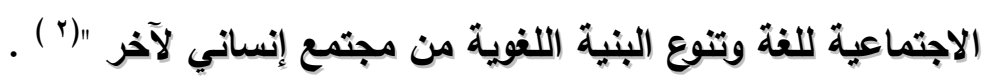

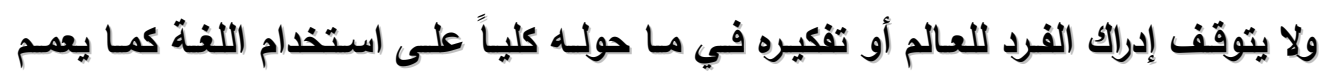

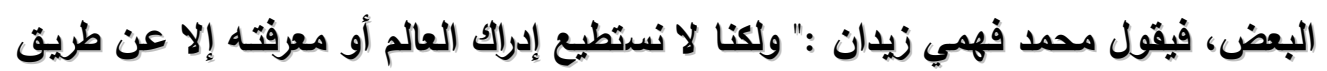

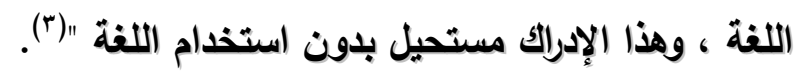

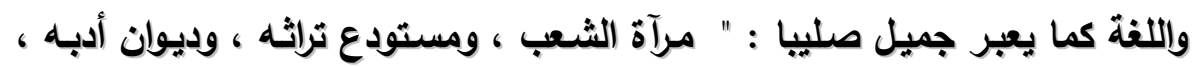

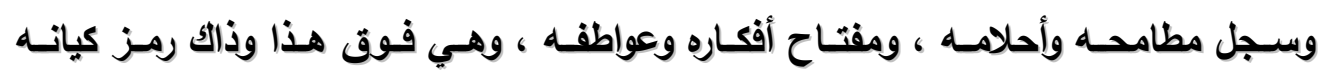

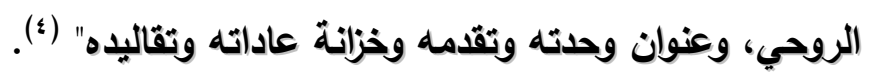

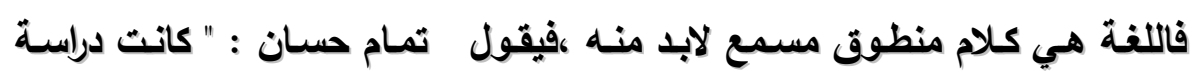
الكـلام المنطوق المسـموع مقدمـة لابد منها لدراسـة الأنظمـة (القواعد ) اللفويـة أو بعبـارة

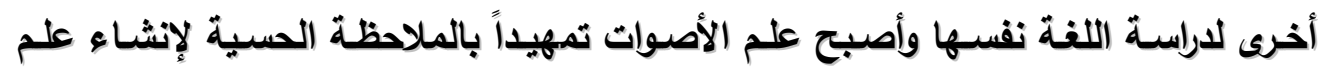
الصوتيات الأي هو تخطيط عقلي لقواعد الأصوات بناء على هذه الملاحظة الحسية"(ه).

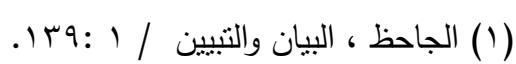

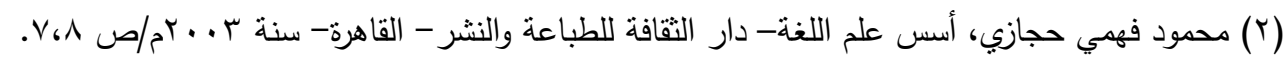

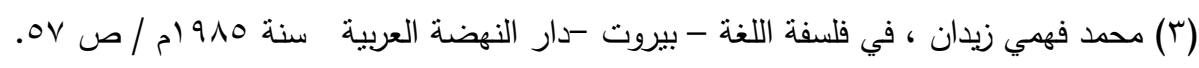

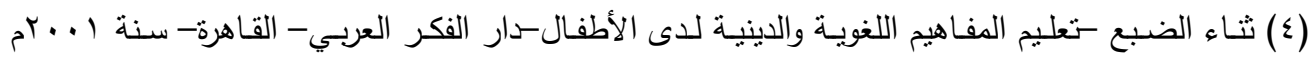

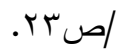

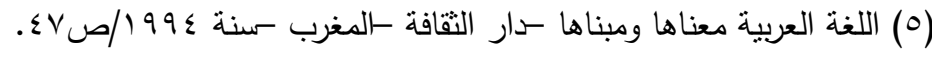

$$
\begin{aligned}
& -\varepsilon \cdot r \text { - }
\end{aligned}
$$


د. يوسف عباس علي حسين

فمن خلال الكلمة نستطيع أن نطل ، و" اللغة هي الظاهرة الأولى في كل عمل فني

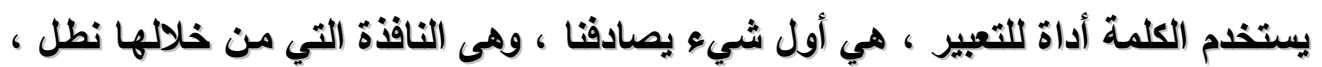

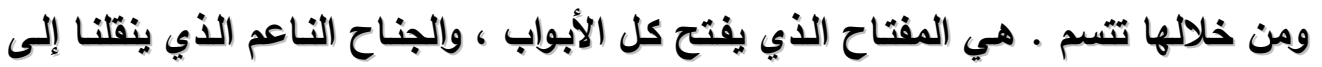

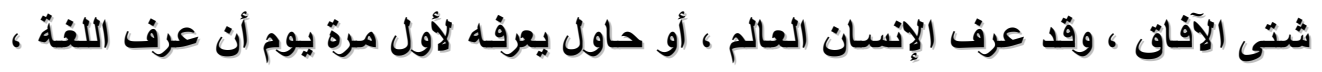

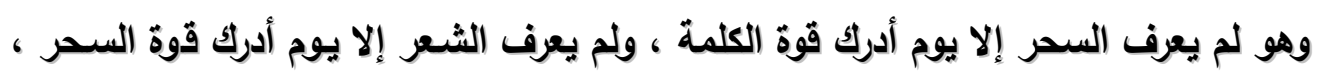

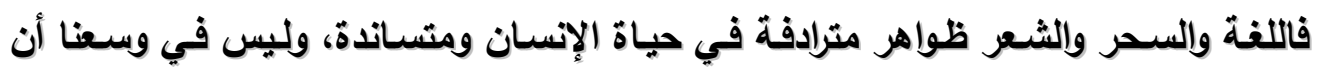

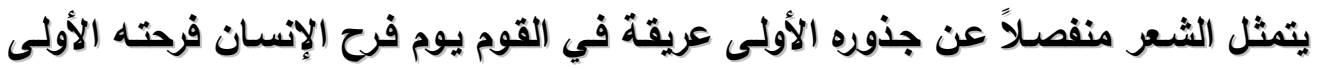

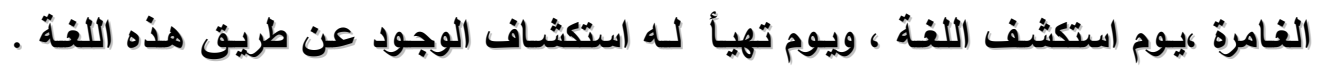

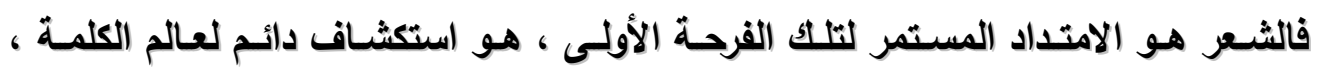

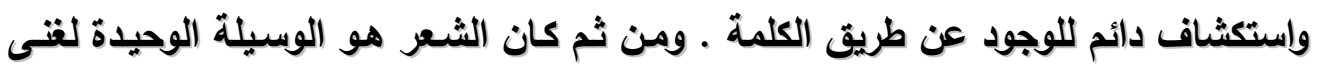

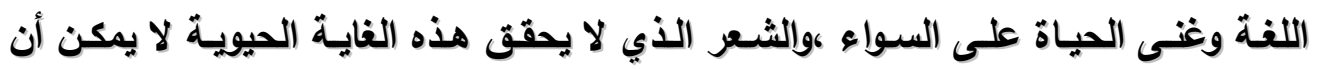
يسمى شعراً بحق" (1)

والثـعراء - أحسـ أفراد هذه المنظومــة الاجتماعيـة - يهتمـون بتصـوير المشــاعر والانفعالات ، فيقول عبد القـادر القط : "ومنـذ بـأ الثـعراء يتجهون إلى التجريـة الذاتيـة

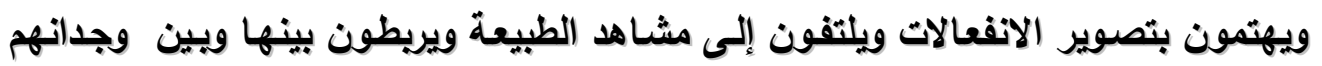

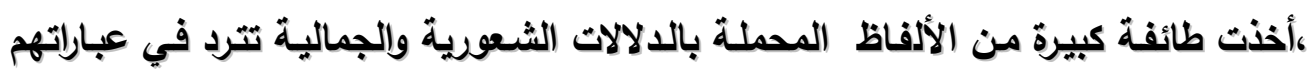

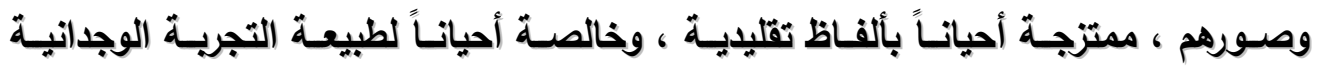

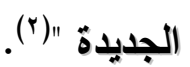

فالشعر هو اللغة الإنسانية الأولى ، و"الثاعر يفكر بالصور ، والتعبير بالصورة هو

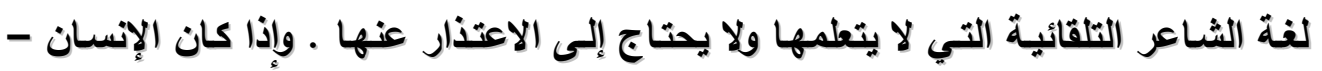
وليس الشاعر وحسب - يدرك المحسوسات ويتعرف عليها قبل المجردات ويفكر بالتعبير

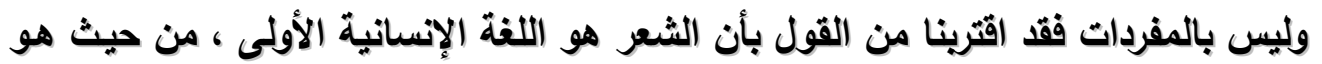

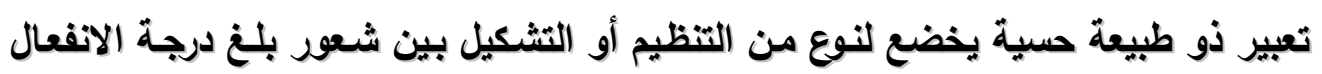

$$
\begin{aligned}
& \text { (1) عز الدين إسماعيل - الثنعر العربي المعاصر " قضاياه وظواهره الفنية والمعنوية "- دار الفكر العربي - }
\end{aligned}
$$

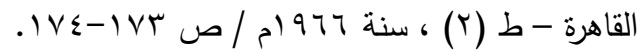

$$
\begin{aligned}
& \text { (Y) عبد القادر القط - الاتجاه الوجداني في الثـعر العربي المعاصر - مكتبـة الثـايب - القاهرة ، سـنة }
\end{aligned}
$$

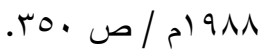


مُستويات الإيقاع في شعر العطوي "من الصوت إلى النص" ــ

فحرك الخيال الأي تأطر في سلسلة من الصور"(') ويعد ، يُعد فهمنا لبناء اللغة والصورة ، وما بينهما من وشائج تجعل الفصل بين أجزائها مستحيلاً . ويقول إحسان عباس : " ومن الاختلاف في التطبيق يجئ التفاوت بل الاختلاف

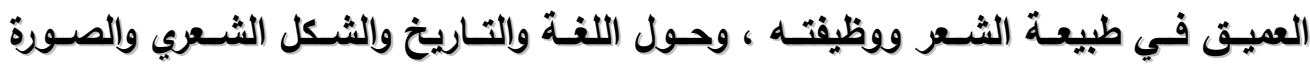
الشعرية- مما ألمعت إليه من قبل - فأصحاب الماديـة التاريخية يتحدثون ببسـاطة وعفويـة وفية إلى الجمـاهير لأنهم يرون أن الثـعر فعال في تنبيـه الـوعي ، واللدفع نحو الثورة ، وهذا اللون من الثـعر يظلب عليه الوضوح في لغته وصوره ورموزه ، وعدم التعقيد في بنـاء

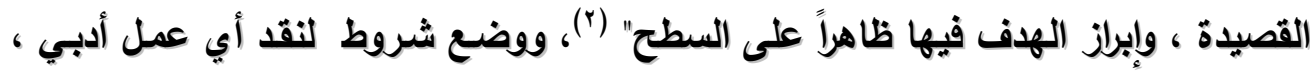

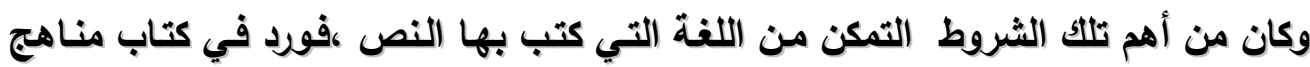
النقد الأدبي : أن" الشرط الجوهري لذقد أي عمل أدبي هو التمكن من اللفة التي كُتب بها هـاب ،

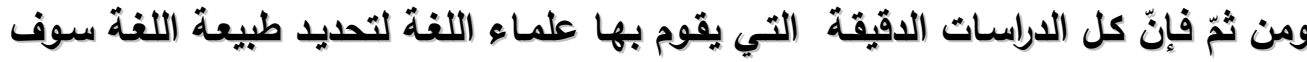

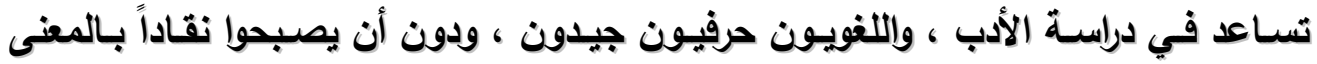

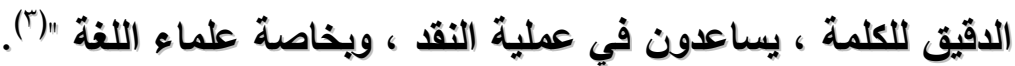

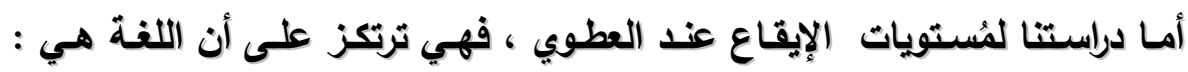
(خلاصة التجرية) بكل ما تتضمن من ألفاظ وصور وموسيقى، وغيرها، وعلى التسليم بأن الأديب في محاولته المستمرة للكشف عن الجوانب الجديدة في الحياة ، فكل تجربة لها لغتها الخاصة ،فيقول السعيد الورقي: "والثاعر في محاولته المستمرة للكثف عن الجوانب الجديدة في الحياة وللكثف عن صورة هذه الجوانب الجديدة داخل وعيه الفردي والجماعي ، وصورتها المنصهرة مـع مكونـات لا وعيه ، يحاول باستمرار الكشف عن لغة جديدة .

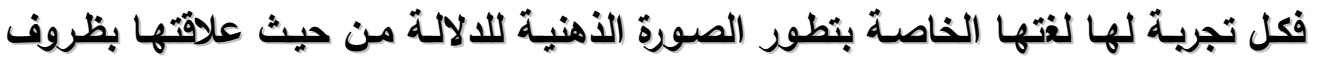
معينة وأفكار وتصورات وآراء وقضايا تتشكل باستمرار يتناسب وواقع الحياة المتغير" (؛ ).

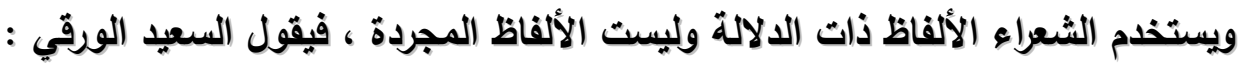

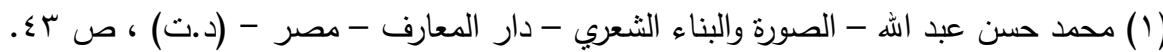

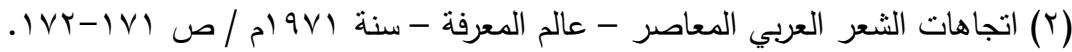

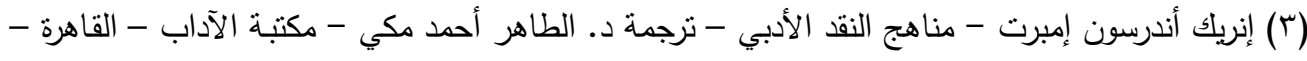

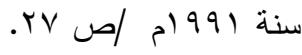

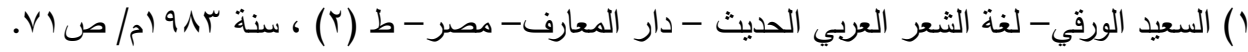


د. يوسف عباس علي حسين

"فالكلمـات لدى الثـاعر ليست مجرد ألفاظ صوتية ذات دلالات صرفية أو نحويـة أو

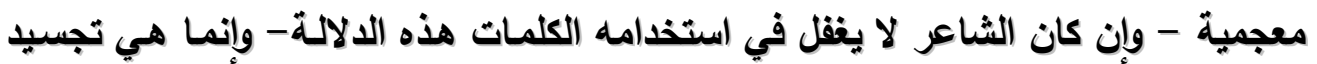

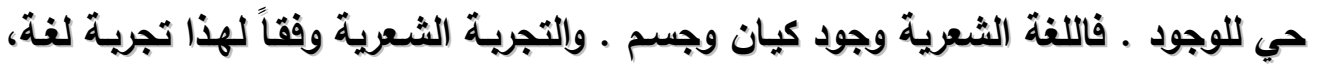
فالشاعر ينطلق إلى العمل من وحدة عاطفية كما يقول هربرت ريد، وهذه الوحدة تكتسي بما يمكن أن يسمى بالصورة اللفوية الداخلية " ( ' ). فيجب على الثاعر أن يختار الألفاظ الموحية ذات الدلالة، لأن بعض الكوريه الكلمات تصلح

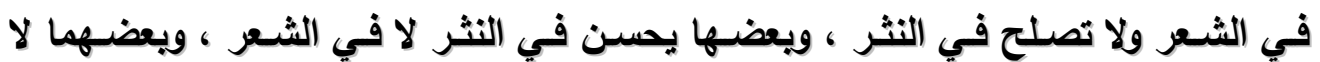
يحسن فيهما .والتي نسميها غير الشعرية لغة العطوي الشعرية : لغنية

لا نقصد بالمستوى الثعري للغة قصورها على الثعر دون النثر ، وإنما المقصود

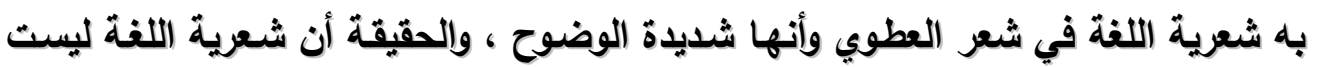

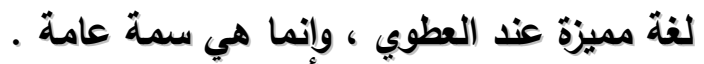

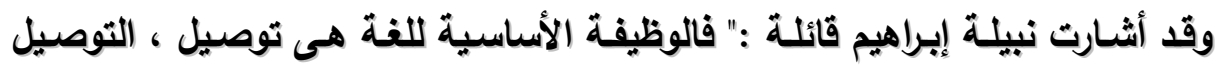

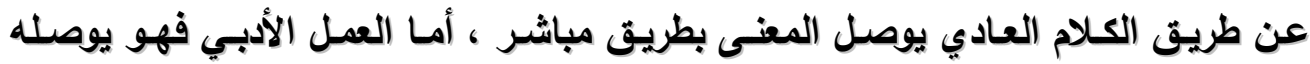

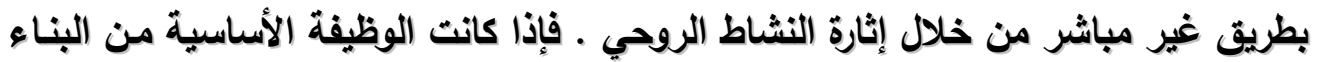
الإنشائي تلبية الاحتياجات الإنشائية . فإن هذه الوظيفة يقابلها في اللغة التوصيل والبحث

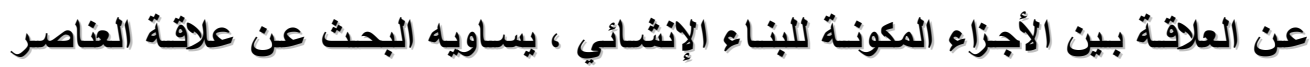

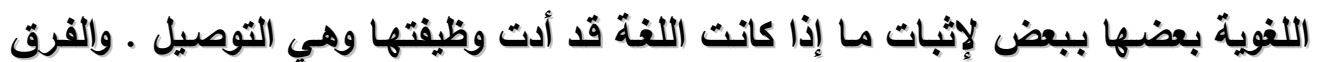

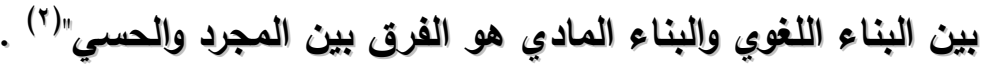
وفي شعر العطوي كغيره تتزايد هذه الثعرية اللغويـة ذات البنبة الثعرية على نحو

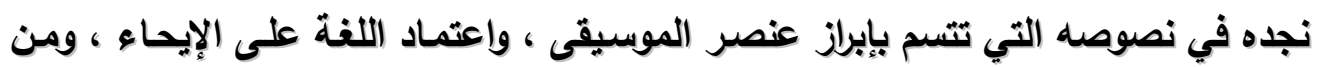

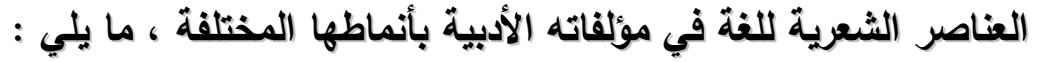

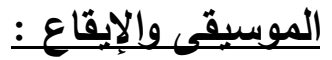
(ץ) البنائية : من أين وإلى أين ؟ -مجلة فصول - الهيئة المصرية العامة للكتاب -القاهرة -العدد (؟)-سنة 
لا شكّ أن الموسيقى خصيصة الثعر الأولى ، وأنها من أبرز معالم الثعرية في أي

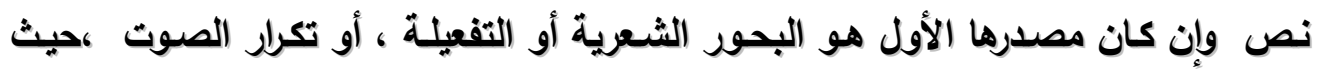

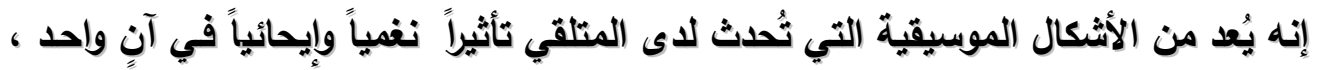

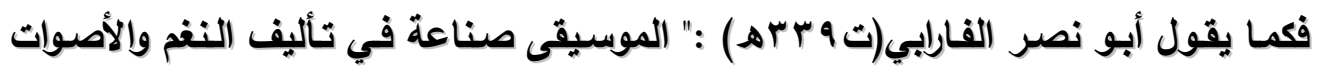
ومناسباتها وإيقاعاتها وما يدخل منها في الجنس الموزون والمؤتلف بالكمية وإلكيفية .

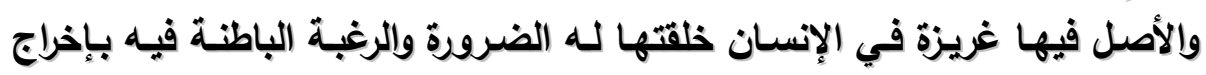

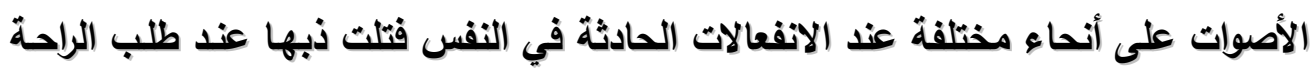

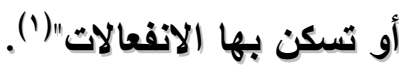
كذلك فإن علم الموسيقى يختلف عن بقية العلوم" بسبب انعدام صورة المـادة في

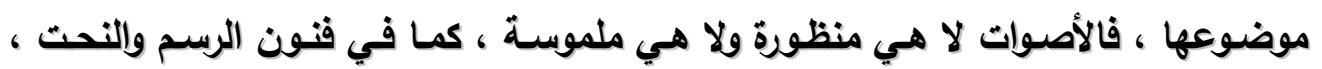

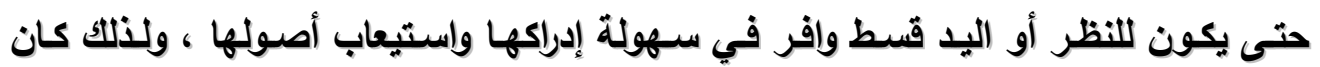

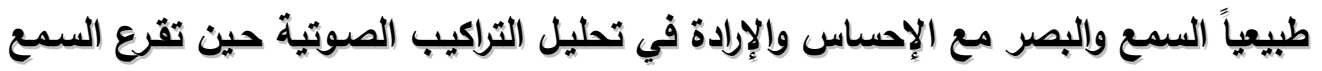

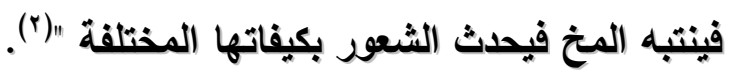

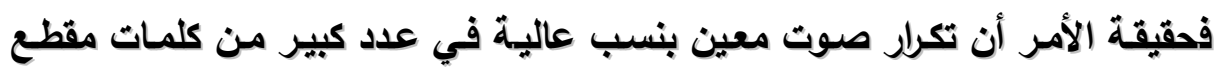

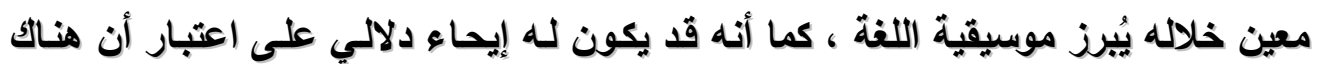

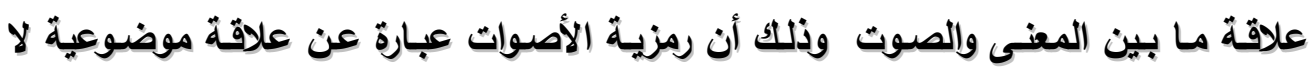

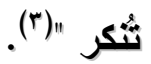
ومما لا شكّ فيه أن العطوي كغيره من الثعراء يميل إلى " الحزم الصوتية التي تتمثل في بث مجموعة من الأصوات المكررة في نسيج الخطاب لإثارة طاقتها الإيحائية الكامنـة

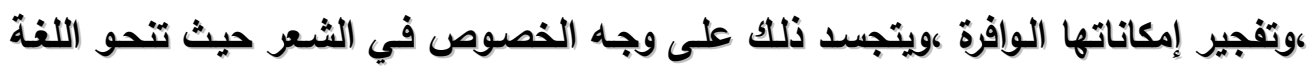
إلى تجاوز طابعها الاعتباطي المتعف في العلاقة بين الصوت والمعنى أو الدال والمدلول

$$
\begin{aligned}
& \text { (1) كتاب الموسيقى الكيير-تحقيق وشرح غطاس عبد الملك خشبة سـار الكاتب العربي للطباعة والنشر - }
\end{aligned}
$$

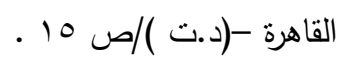

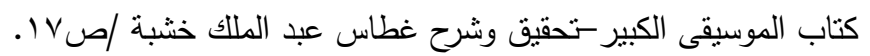

$$
\begin{aligned}
& \text { رومان جاكبسون - قضايا الشعرية - ت /محمد الولي ومبارك جنوز -ـدار توبقال - المغرب سـنة } \\
& .0 \leqslant / 319 \lambda \mu
\end{aligned}
$$

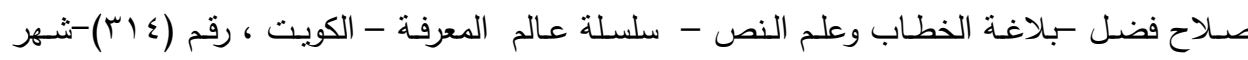


د. يوسف عباس علي حسين

ومن نمـاذج التركيز على تكرار صوت معين ؛ لتحقيق توافق نغسي ، وتقديم الجو

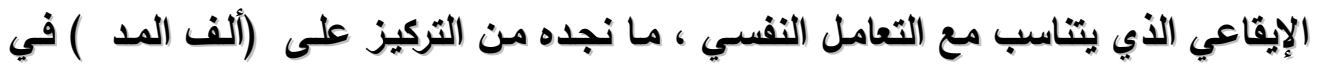

$$
\begin{aligned}
& \text { جلّ رب الأعراض والأجسام عن صفات الأعراض والأجسام }
\end{aligned}
$$

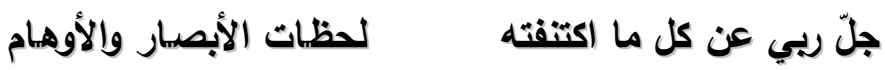

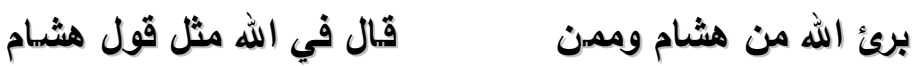

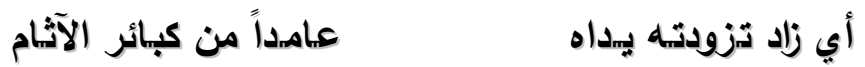

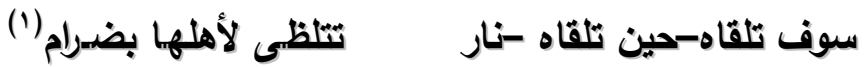

إن تكثيف ألف المد في الأبيات السابقة في كل من:" الأعراض - الأجسام -الأبصار

-الأوهام-هشام - الآثام-نار" يوحي بنبرة التضرع الله سبحانه وتعالى وتنزيهاه عن التشبيه

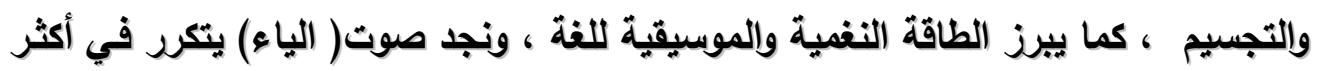
من موضع في الأبيات التالية :

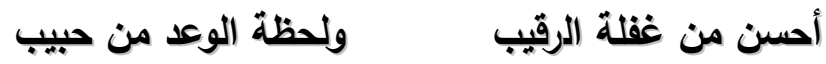

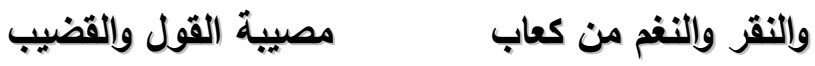

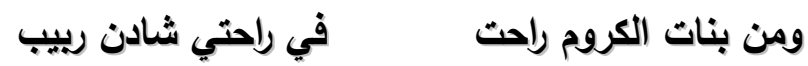

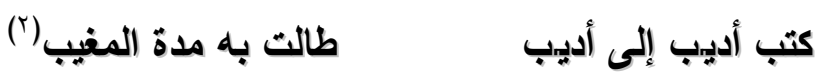

فنجد أن صوت الياء يتكرر بصورة عالية في " الرقيب - حبيب -القضيب -ريبب-أديب - المغيب" كما يؤدي تكرار بعض الأصوات في عدد كبير من كلمات بعض الجمل دول دوراً مهرماً

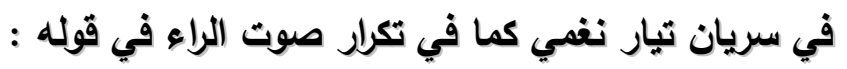

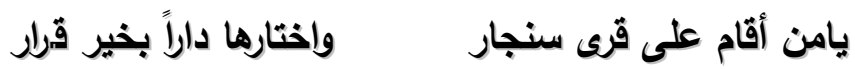

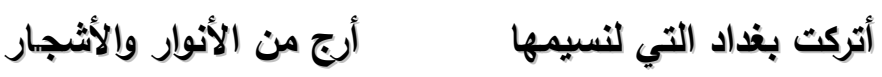

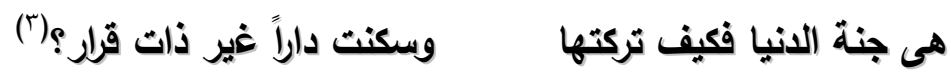
فنجد في الأبيات السابقة أن صوت " الراء" تكرر في عدة كلمـات هي "قرى -اختار -دار -

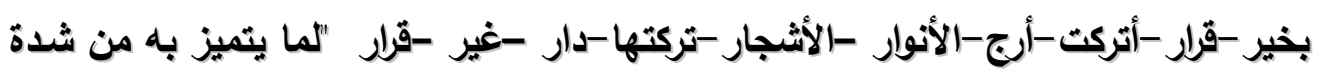



مُستويات الإيقاع في شعر العطوي "من الصوت إلى النص" ـ

وقع على السمع ، وقد يكون التكرار لصوتين متقاربين في المخرج كتكرار صوتي السين

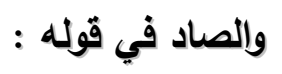

شسعاً وحصراً أصرَ القوم أو ترعوا

عندي لهم أنني أرعى أواصرهم

حبل الصفاء كغيب ليس يطلع

وإن أسرارهم عندي وإن قطعوا

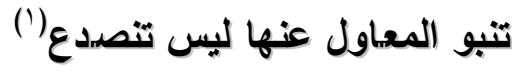

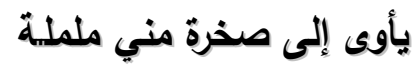

فتكرار صوتي السين والصاد هنا في كلمات عدة منها " أواصر-شسع-حصر-أصر

-أسرار-الصفاء-ليس-صخرة -ليس" ، فهما من حروف الصفير ، التي تؤثر في مراكز

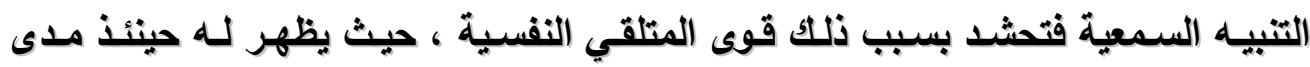

الأهمية ، وقد يكون التكرار لصوتين غير منفصلين ، كتكرار الضمائر المتصلة في قوله :

قد ألحت عليه شهب سنيبه

عاد منا الفقبه غير فقيه

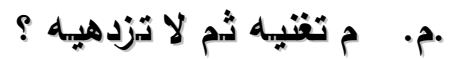

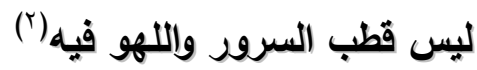

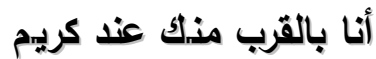

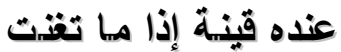

تزدهيني، وأين مثلي في الفه

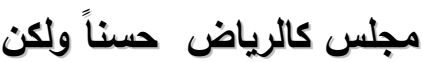

مـن الواضـح خـلال الأبيات السـابقة التكثيف الشـديد لتكرار الصـوت في في معظم كلمـات

$$
\text { الأبيات " عليه-عنده-تغنت-مثلي -تغنيه -تزدهيه-فيه" . }
$$

وقد يأخذ التكرار شكلاً آخر ، يتمثل في تكرار كلمة أو أكثر في أوائل الجمل أو أو الفقرات وهذا التكرار بجانب قيمته الموسيقية يعكس لنا مدى التوتر والاتفعال المسيطرين كما أنتا لا نستطيع أن نففل دور إيقاع الجمل حيث التوازي في اتساق الجمل المتتالية ،

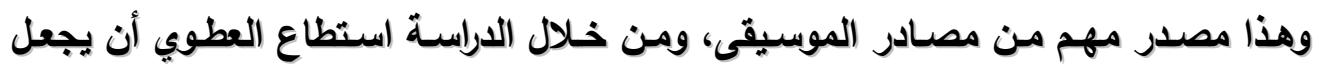

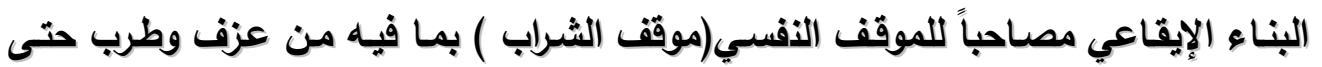

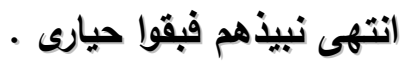
فنرى العطوي قائلاً:

بيشراك لما أتاني الخبر أتبتيتك جذلان مستبشرا

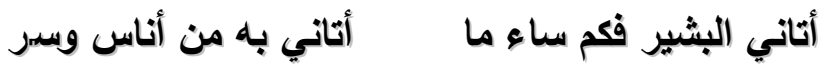


أتاني يذكر أن قد رزف فقد كرر الثاعر في الأبيات السابقة كل من (أتيت - أتاني - مستبشر -بيشراك -البشير)،

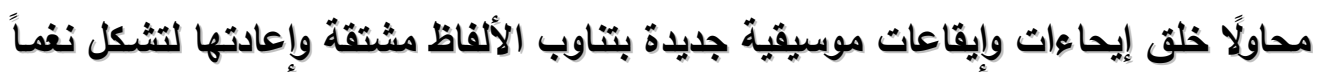
وموسيقياً.

كما يقول الثاعر في الراح واستطابتها واستدفاع الغم بها: في الراح لي راحة بعض ما أجد

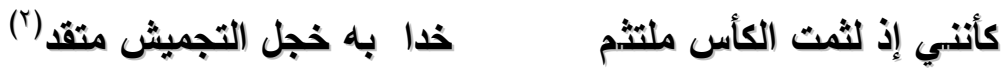
فهو يكرر الثاعر الكلمة بمشتقاتها كما نلحظ في كل من "الراح - راحة - فسقتيها- سقاك

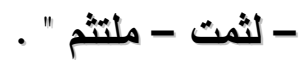
كما يقول الشاعر في الخمر :

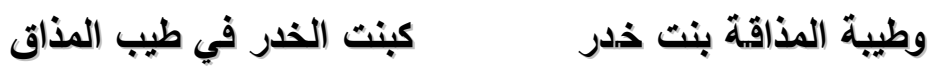
فصرت بشربها عمر الملاهي وأطلقت الفؤاد من الوثئق

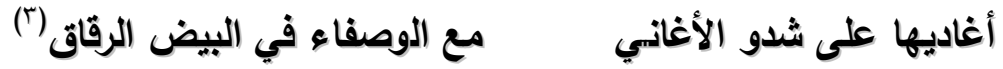

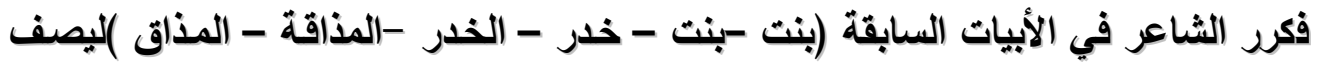

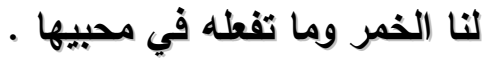
ويقول في اختيار النديم : يقولون قبل الدار جار مجاور وقبل الطريق النهج أنس رفيق

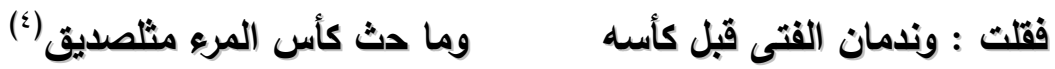
فهو يؤكد لنا أهمية اختيار الأصدقاء ، ذاهباً إلى مواكبة الضمير الشعبي الحي ...واعتقاده

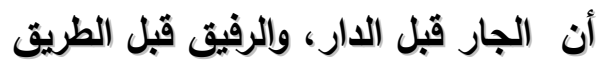
والموسيقى عند الشعراء سمة بالغة الأهمية لا يمتلكها سوى الثاعر الفحل هلئ ، وفي

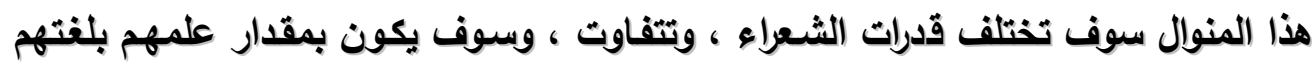

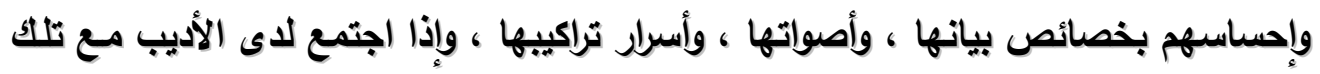

$$
\begin{aligned}
& \text { (1) ديوانه /ص الو } 9 .
\end{aligned}
$$

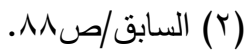

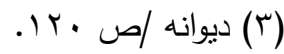

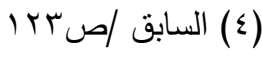


السـمات استعداد وفطرة وصبر ودريـة ، مكنته مـن أن يأتي من فنـون الأدب بالأعاجيب

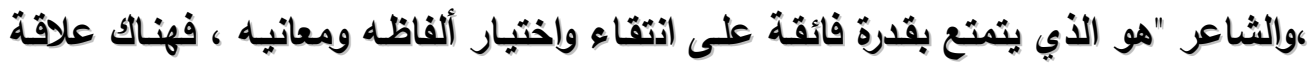

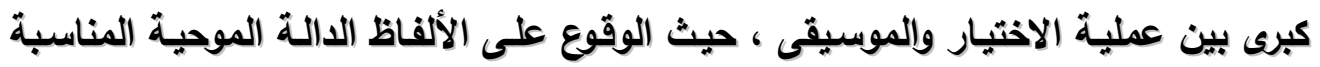
ذات الوقع الصوتي المنبه هو هبة لا يوهبها إلا من يتمتع بحدس عظيم والإن وحساسية مرهفة

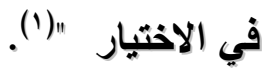

وسوف نجد أثناء عرضنا لشعره ما يكشف عن ضعف الانفعال وقوته ،وعن ثورته على أن سرعة الانفعال وتوقد الإحساس كانـا من سماته الملازمـة إلا في النادر القليل ،

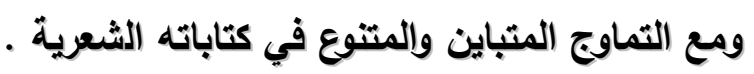

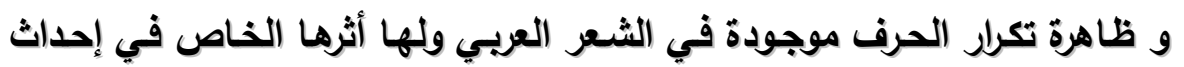

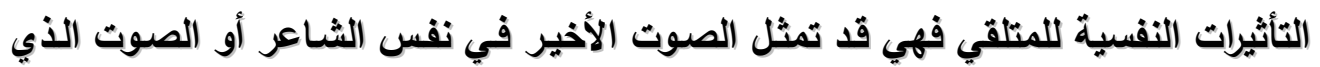

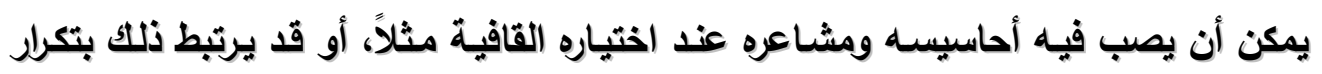

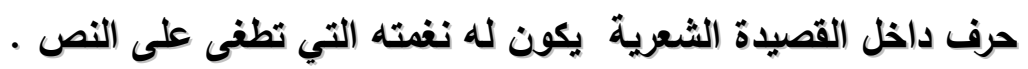

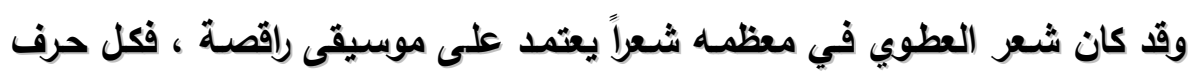

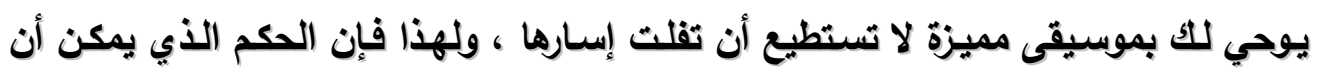

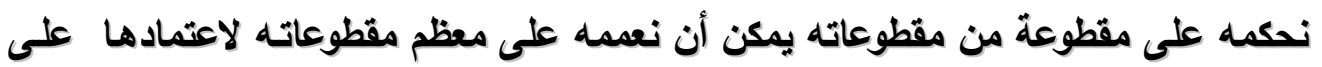

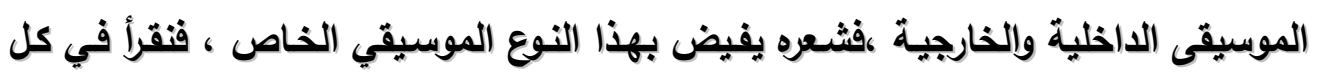

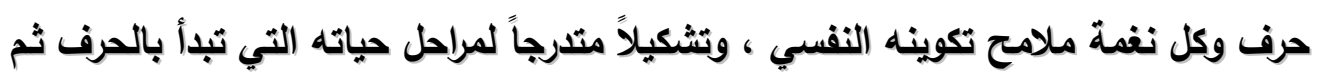

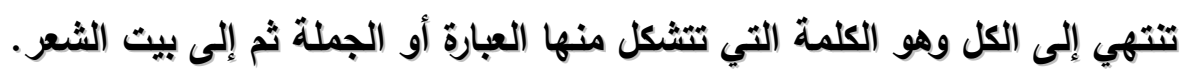

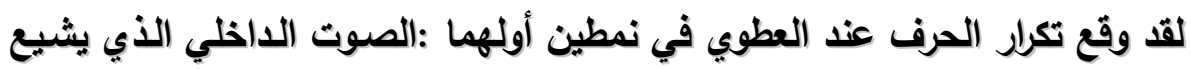

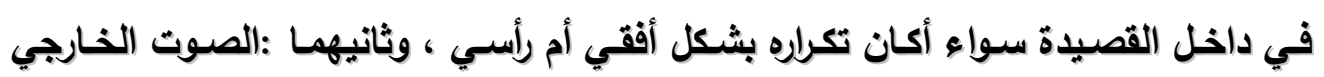

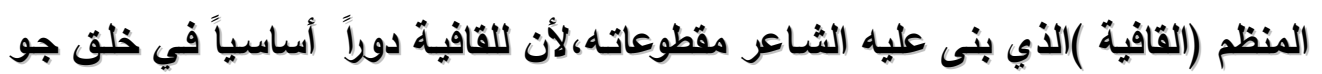

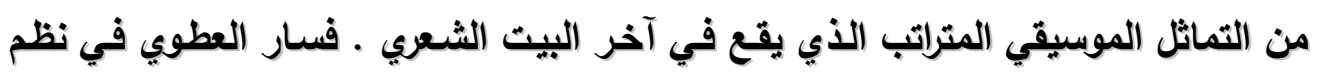

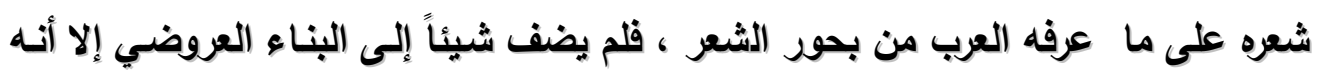

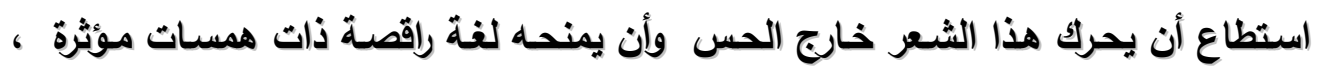

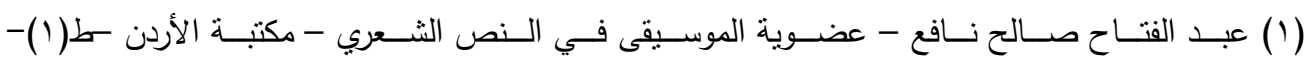

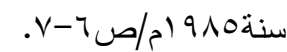


فنرى أغلب شعره اتخذ شكل المقطوعة مما أدى إلى عدم تعدد الشـاعر لقوافيه ، وإنما كرر

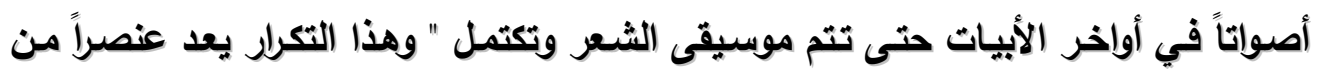

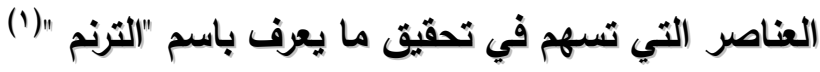

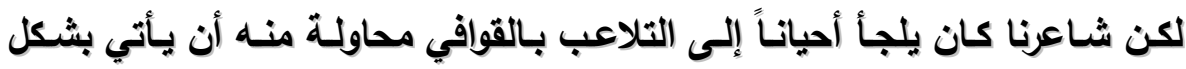
جليد من القوافي أو بنمط أسلويي مغاير للمألوف رغبة منـه في الخروج من أسر التقليد

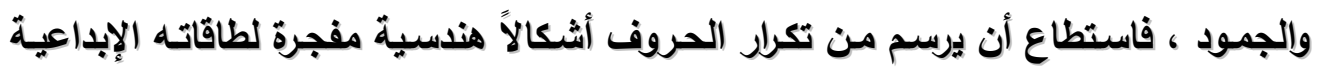

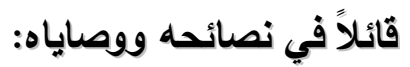

فاخلع لباسهم بالعلم والأدب الصر يانس بين الحرص والطلب

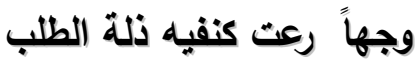
أقبح بوجه يسيار كان قائده

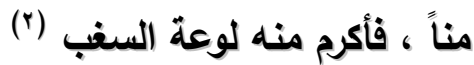

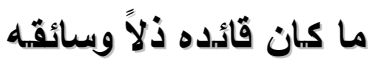

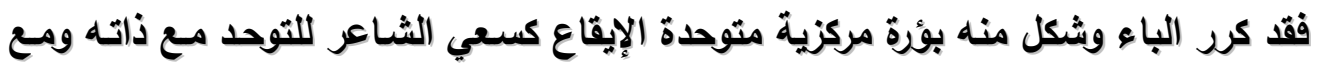

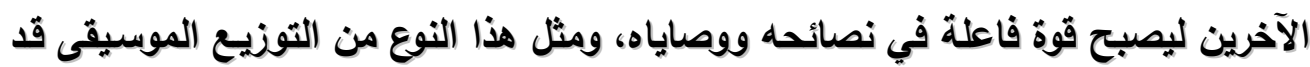

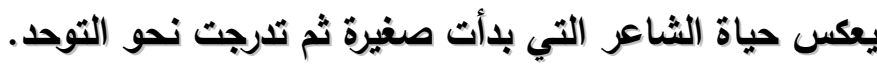
كما كرر الثاعر بعض الحروف كدرف السين بشكل خضع لبعض التداعيات ، قائلاً:

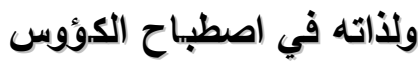
سرور الفتى يُوم لذاتهـ هي الشمس حين مغيب الشموس هى السعد يوم يغيب السعود لمون وما خلقت غير أنس النفوس هين ميناب) ولم يخلق المـال إلا لهيا فكرر الشـاعر حرف السبن بشكل مكثف ، حيث إنها من حروف الصفير أو من الحروف

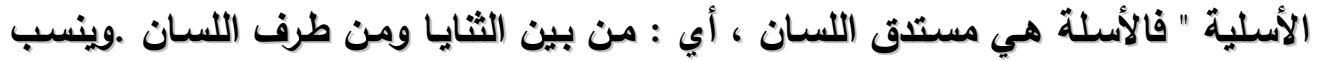

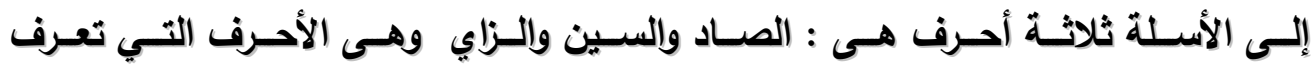

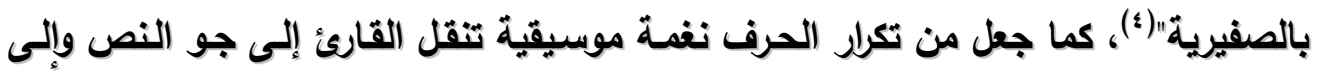

( (1) حازم علي كمال الدين - نظريـة المناسبة الإيقاعية في القافية - مكتبـة الآداب - القاهرة ط(1)-سنة (r)

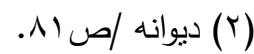

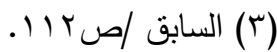
(ع) رشيد عبد الـرحمن العبيدي - معجم الأصـوات -مكتبـة مـروان العطيـة - مركز البحوث والدراسـات

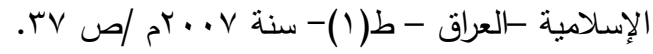



مُستويات الإيقاع في شعر العطوي "من الصوت إلى النص"

طبيعة الموقف الذي عاشه الثاعر (تمجيد الخمر )، فجسد من خلال الكاف كثفاً واضحاً لتجربة الشاعر كما في قوله :

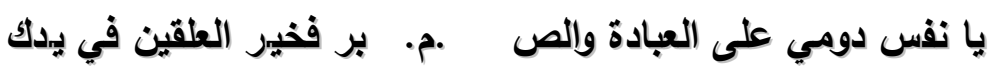
إنسي وإن كنت لابسياً سميلاً

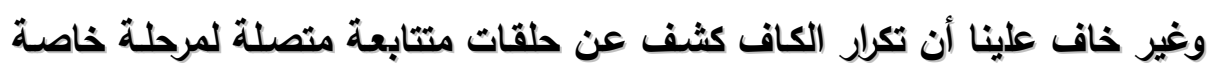

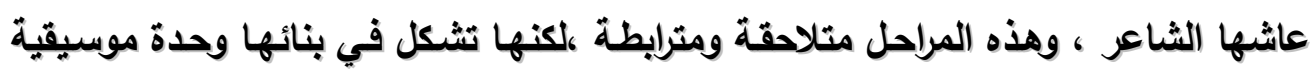

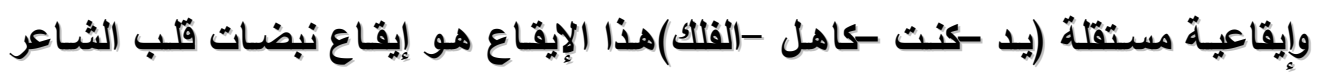
وزفراته التي كان ينفثها ، لأن الصوت يجسد الإحسـاس ويجعل السـامع يستشعر المعنى ويمكنها الرحيل من ضجة الدنيا والانفصال عنها. 
لا شـك أن الأصـوات تثـكل قــة جماليـة وإيقاعيـة فـي النص الثـعري ، وإن كانـت

العناية بالأصوات كاتت من قبل اللغويين ، وقلما اعتنت بها الدراسات النقدية .

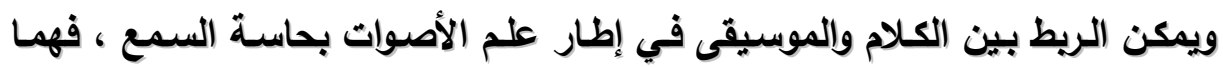

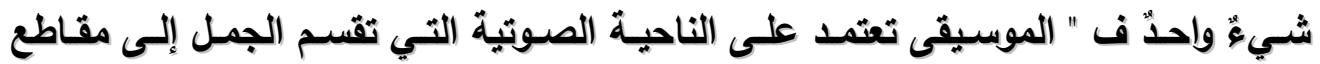

متتاسقة تكون وحدات معينة على ترتيب معين بقطع النظر عن بداية الكلمات ونهايتها.

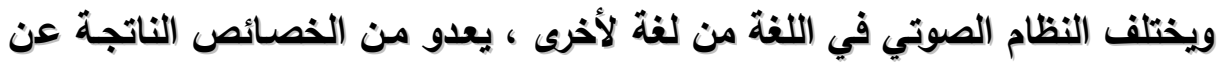

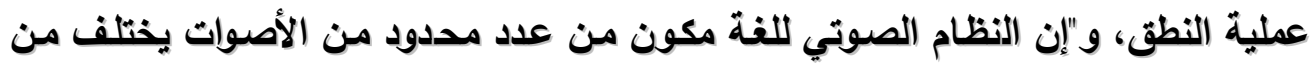

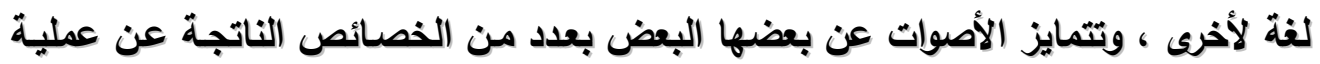

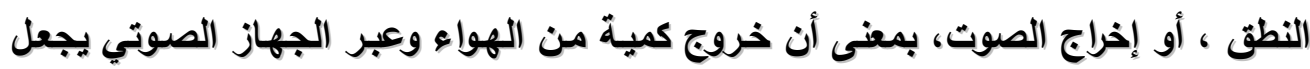

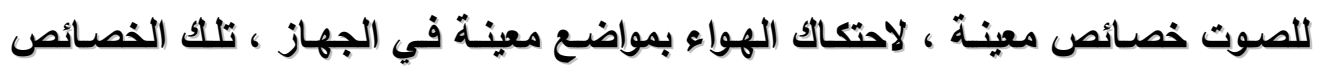

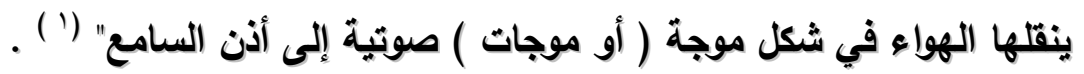

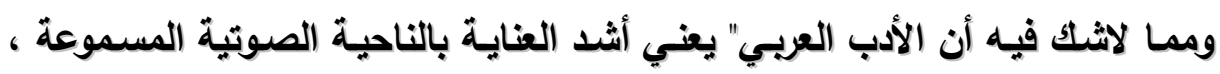

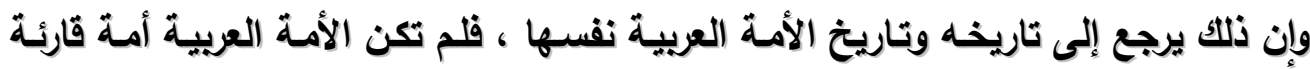

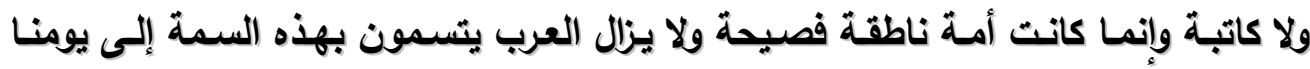

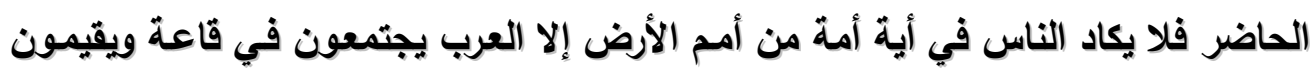

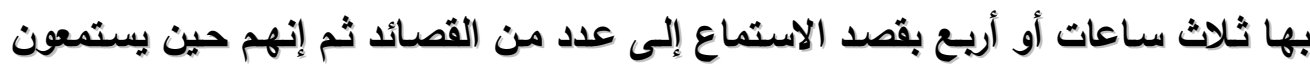

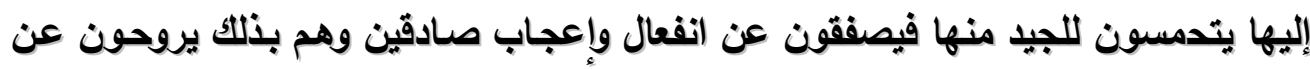
النفس ويستمتعون بمنبع من منابع الجمال، تلك خاصة من خواص العرب وميزة من ميزات

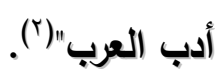

ولا أحد يستطيع أن ينكر دور الأصوات؛ "ورصد أية ظاهرة لغويـة يغني باللغة ذاتها،

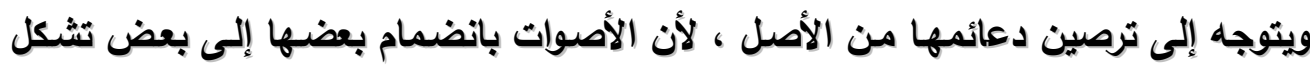

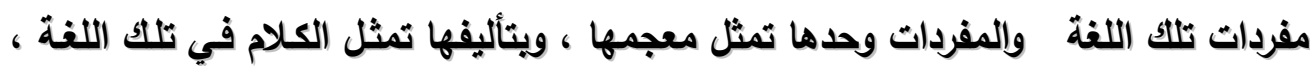
والقدرة على تناست هذا الكـلام وتأليفه من مهمـة الأصوات في تناسقها وتألفها ، وتنـافر

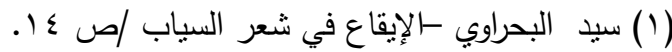

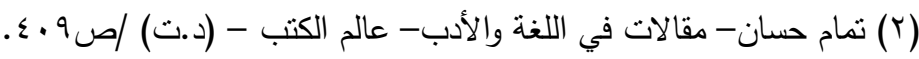

$$
\begin{aligned}
& -\varepsilon 1 \leqslant \text { - }
\end{aligned}
$$


الكلمات وتهافتها قد يعود على الأصدوات في قرب مخارجها أو تباعدها ...ذلك أن اللغـة

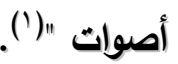
إذن تتولد المعاني من صور لها دلالات صوتية ، والرمز بوصفه يمثل علامـة لغوية،

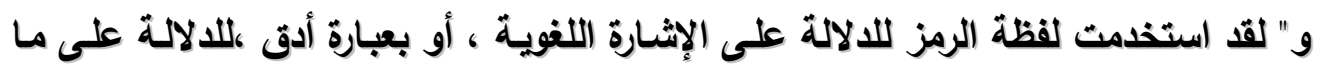

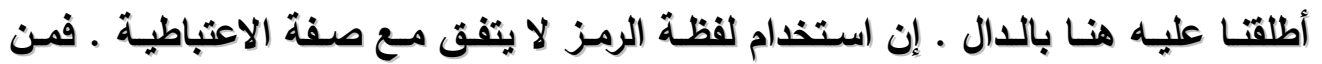

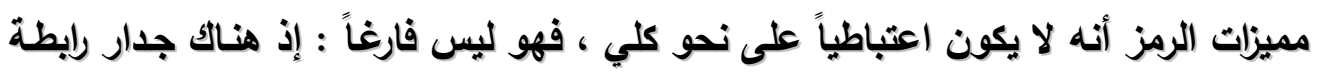

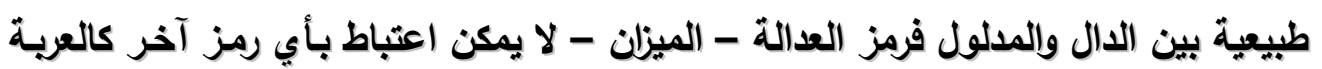
مثلاًً)(')

وغير خافٍ أن الثـعر يستعين بالموسيقى من أجل تحقيق تماسك نسيج القصيدة

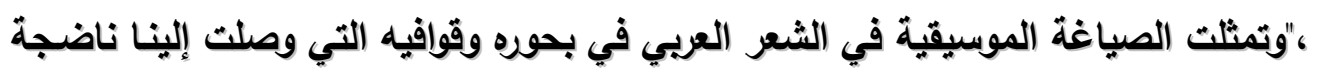

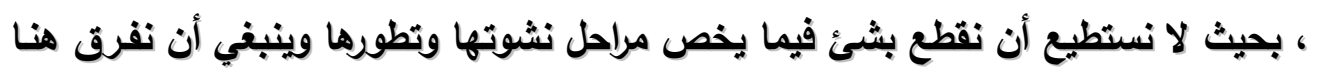

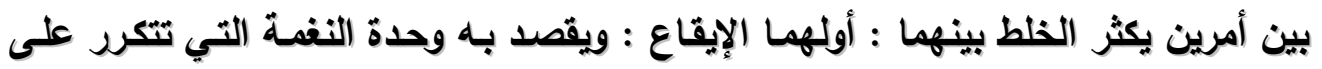

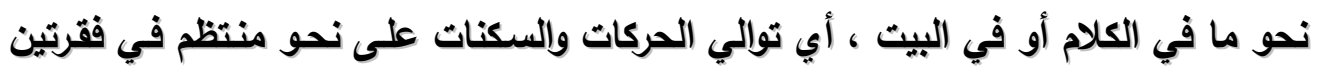

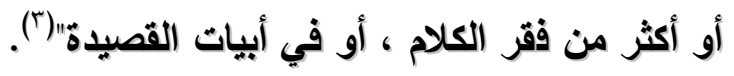

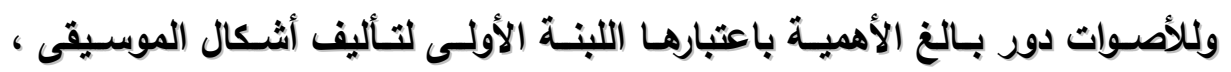

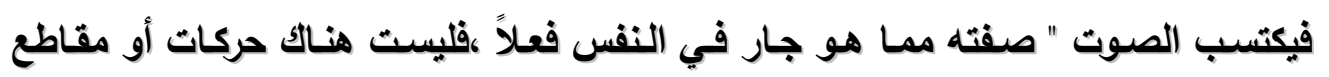

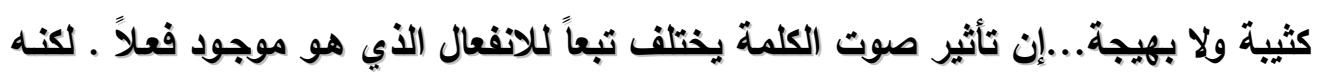

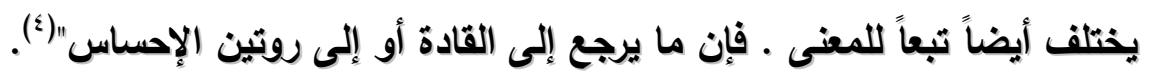

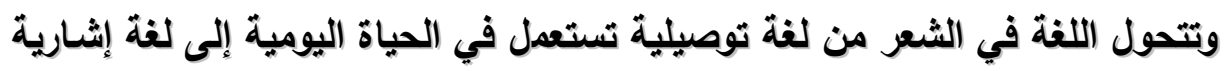

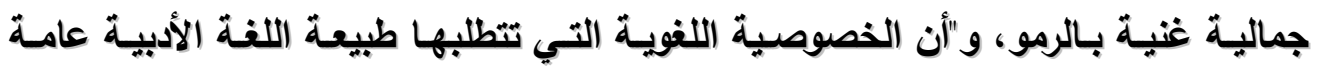

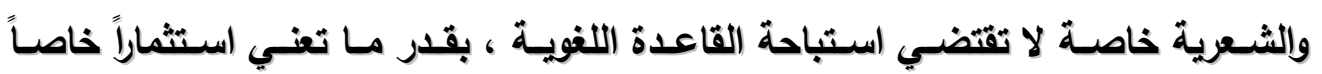

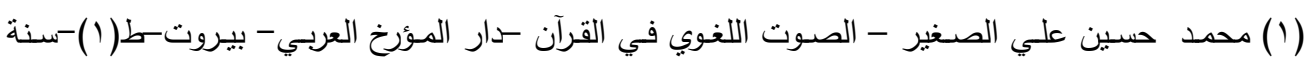

$$
\begin{aligned}
& \text {. } v \varepsilon-V / \mu / r \ldots \\
& \text { (r) فردينان دي سوسور - علم اللغة العام - ترجمة : يوئيل يوسف عزيز - دار آفاق عربية - بغداد - }
\end{aligned}
$$

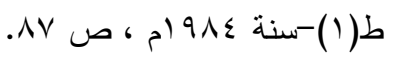

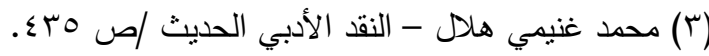

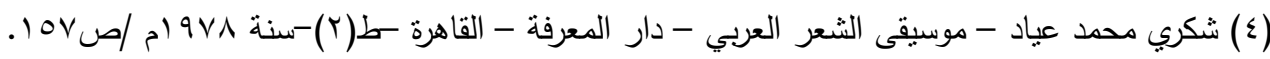

$$
\begin{aligned}
& \text { - } 210 \text { ـ }
\end{aligned}
$$


د. يوسف عباس علي حسين

بالثاعر لطاقات اللغة ابتداء بالصوت ومروراً بالمعجم والبنية الصرفية ، والتركيب النحوي ،

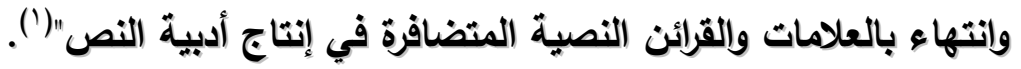

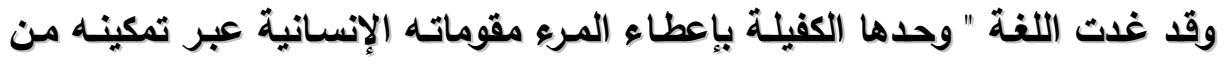
إجراء العملية التواصلية ولو رمنا استغرلق العمق الانطولوجي لقلنا إن اللغة هي العامل الجوهري في إخراج الإنسـان الفرد من عزلته الوجوديـة ، وهى العنصر الفعال في تلطيف

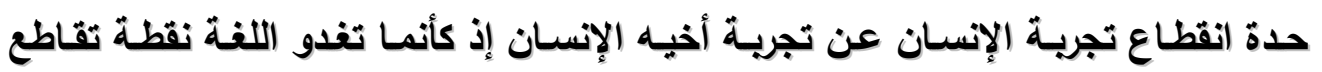
الوقائع المعيشة ويالتالي مركز التقاء الفرد بالفرد ، وليس شئ من هذا هذا ممكنا بغير الإنجاز الوظيفي للغةة"(r). واللغة هي أصوات والأصوات علامات دالة ، فيقول عبد السلام المسدي : "اللغة في ركنها الأول أصوات ، والأصوات علامـات دالة يطلق عليها مصطلح الصواتئم (الفونيمات) وهى تترابط منسجمة في تكامل بحيث تشكل بنية هى البنية الصوتية وكذلك الألفاظ إذ تولا

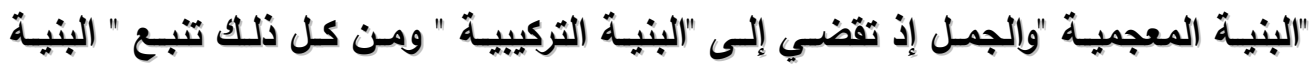

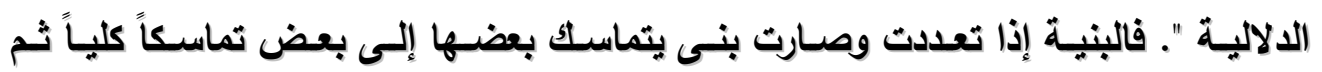

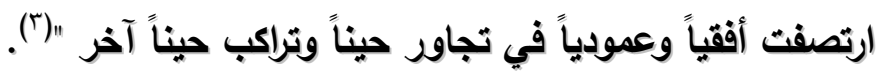

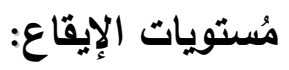
تتعدد الأنماط طبقًا لتنوع تجارب القصائد المختلفة ؛ حيث يكون لكل قصيدة تجريـة

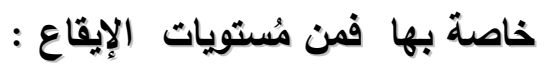

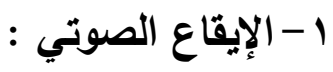

يوجد هذا النوع من الإيقاع في القصائد و التي تتكرر فيها الأصوات ذات التردد العالي ، وهذه القصيدة تترك بصمة وصدى في نفوس الجمهور .فيقول في مدح خالد بن فين

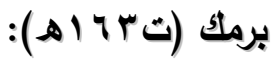

فعل الكرام فعموه الناسـا

لم يهرموا لبنائهم آساسـا
إن البرامكة الكرام تعلموا كانوا إذا غرسوا سقوا وإذا بنوا لنواموا

( (1) محد عبدو فلفل - في التشكيل اللغوي للثعر "مقاربات في النظرية والتطبيق " - منشورات الهيئة العامة

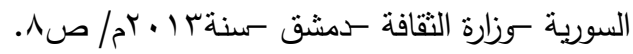

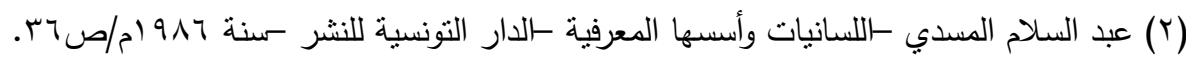

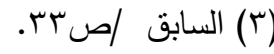


مُستويات الإيقاع في شعر العطوي "من الصوت إلى النص" -

جعلوا لها طول البقاء لباسـا

كأس المودة من جفائك كاسـا

أن القطيعة توحش الإيناسا( (')
وإذا هم صنعوا الصنائع في الورى فعلام تسقيني وأنت سقيتني آنستتي متفضـلا أفلا ترى فيني

فقد استأثرت الأبيـات السـابقة على قوافي موحدة(حرف السين ) ابتداءً بالقافيـة

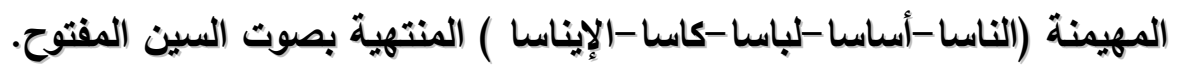

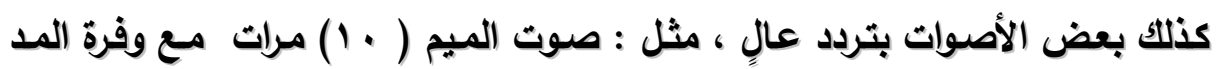

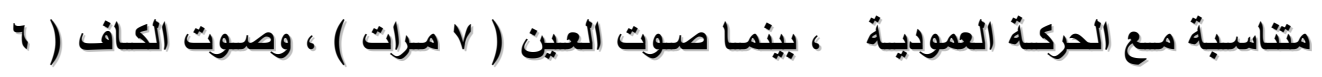
مرات) في الأبيات ، فقد دل تكرار هذه الأصوات المتنوعة ضمن الوحدات على قوة انفعال

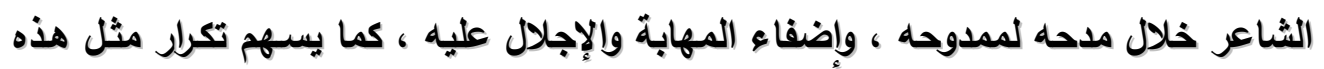

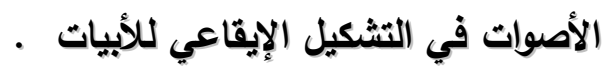
ويقول محاوراً حوارية:

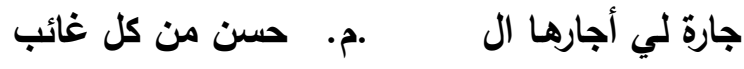

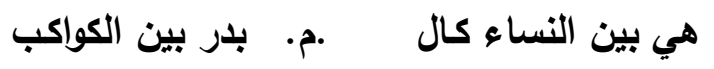

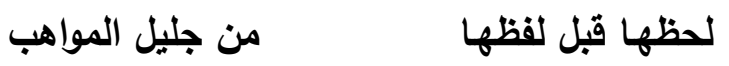

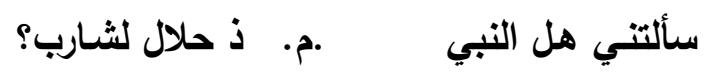

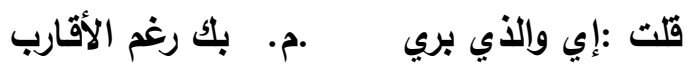

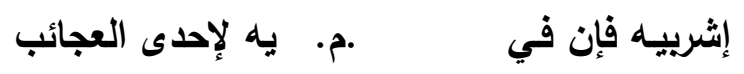

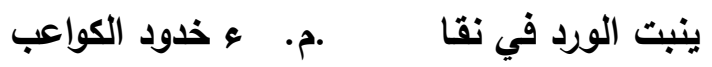

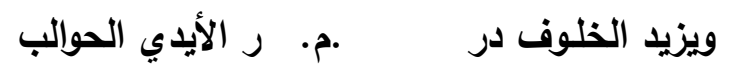

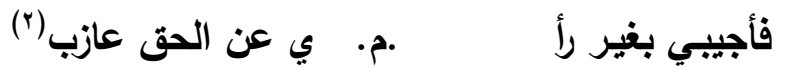

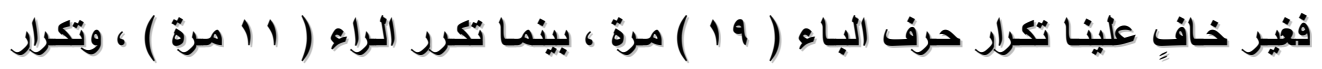

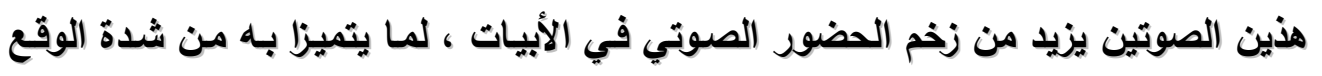
على السمع.

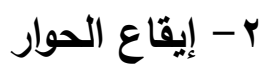

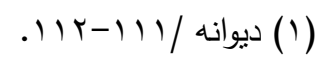

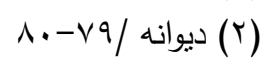


د. يوسف عباس علي حسين

قد يفرض الحوار إيقاعه ، عند تبادل الأثخاص الكلام ، فيُعدُّ الحوار في القصيدة

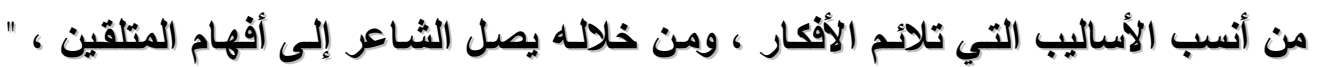

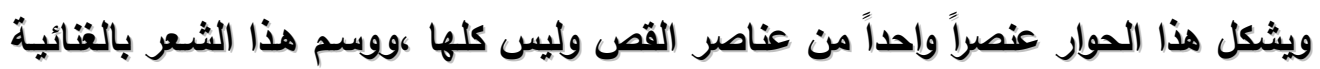

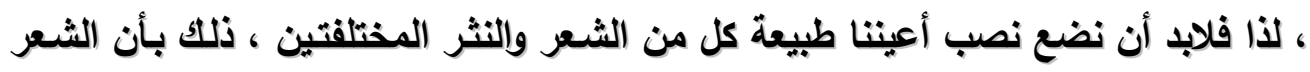

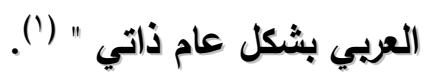

والحـوار يعبر عن الأفكـار العميقـة ويعد التأمسل ، ويعمل على تطوير الأحـداث

ويكشف عما يجول في خواطر الثخصيات .

ولا شــك أن إيقـاع الحـوار يسـاعد فـي تثـكيل القصـيدة، ومعرفـة الحالـة النفسية

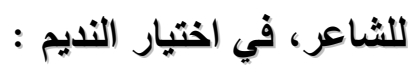
يقولون قبل الدار جار مجاور وقبيل الطريق النهج أنس رفيق

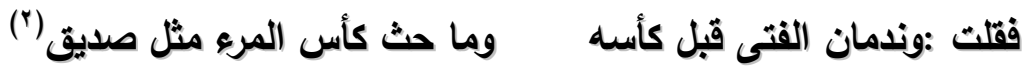

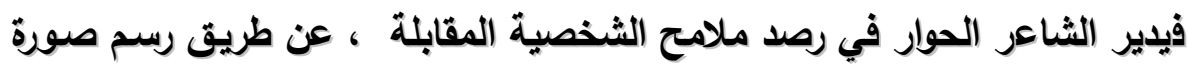

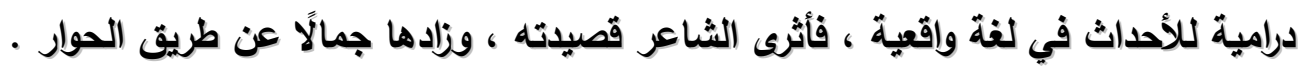

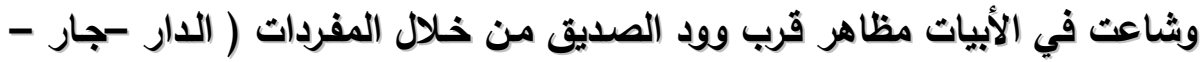

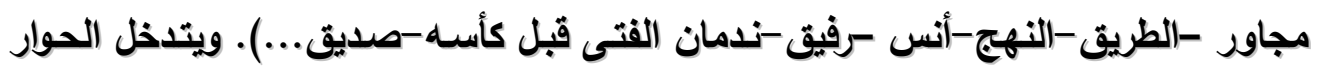
باستخدام الفعل الحواري المباثر " يقولون" و " قلت " مرة على صيغة المضارع ، والأخرى

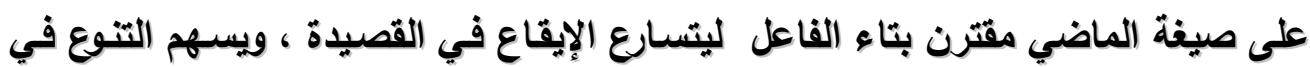

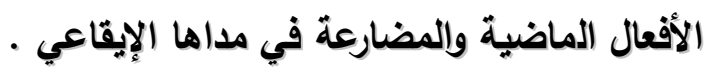
ويقول متغزلاً :

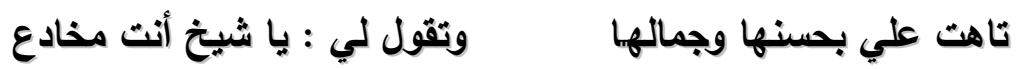

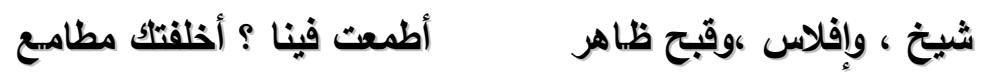
فأجبتها : الإفلاس يذهبه الغتى والثيب يذهبه الخضاب الناصع

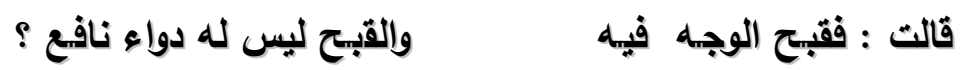

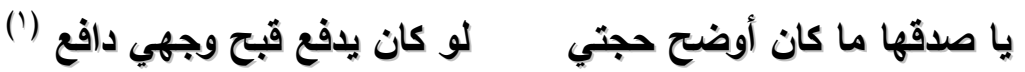

(1) (1حمد سعيد حسين مرعي - الحوار في الثـعر العربي القديم شعر امرئ القيس أنموذجـاً -كليـة التربية

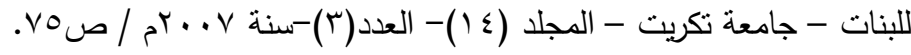

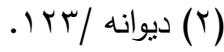




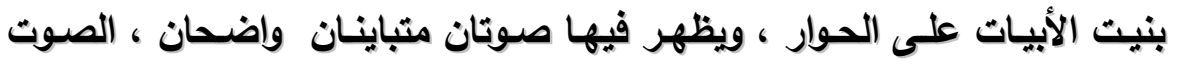

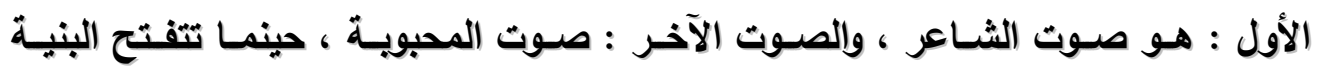

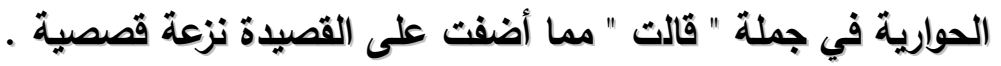
r- بإيقاع الأفكار في جله

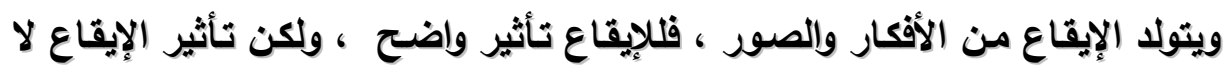

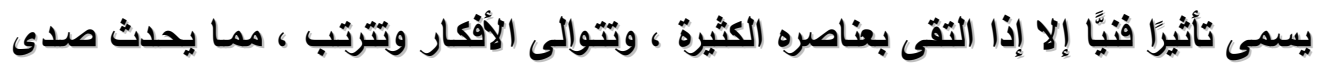

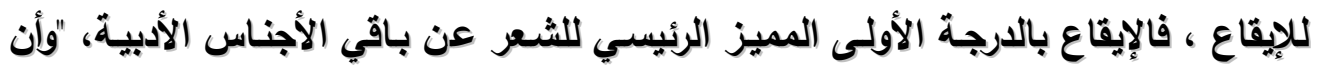

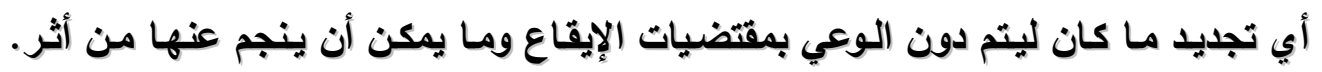

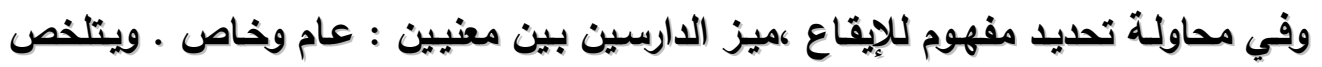

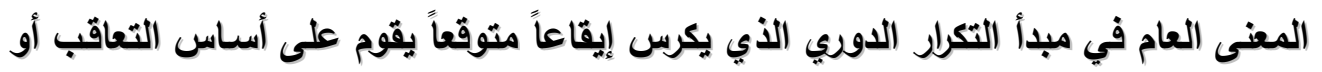

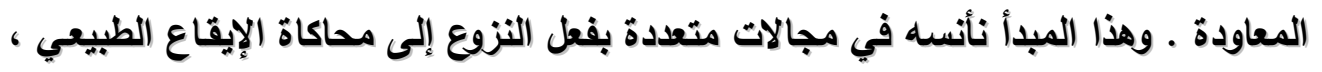

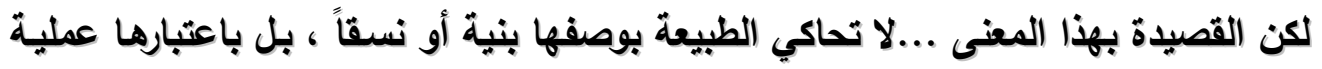

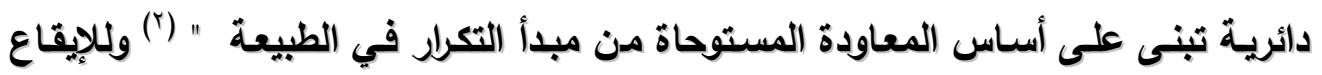

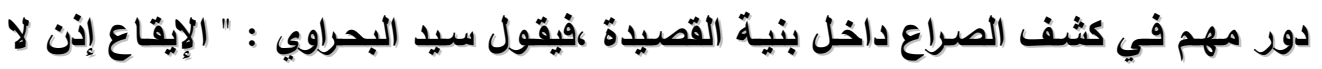

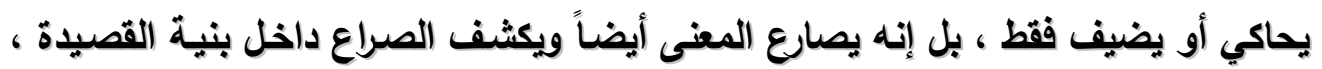

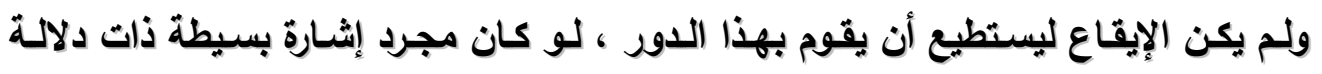
وحيدة ومتفق عليها كإشارة المرور.

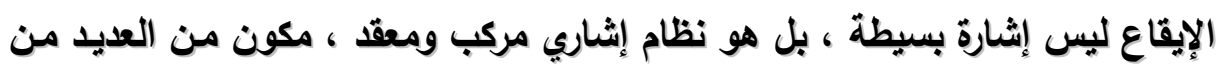
الإشارات ، بل إن كل عنصر من عناصره هو في حد ذاته نظام إثـاري مكون من إثـارات

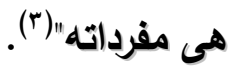
وهناك فرق بين الموسيقى الظاهرة والخفية في التي تتولد في القصيدة ، ولكن

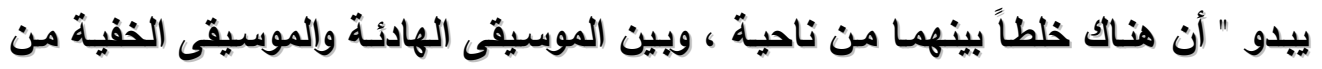

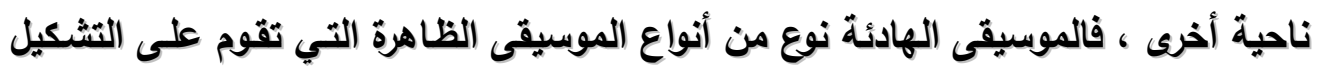

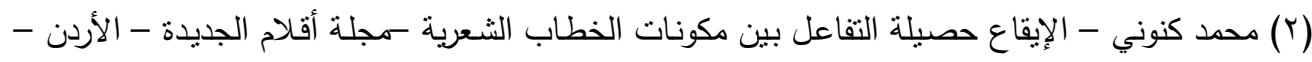

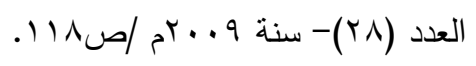

(r) سيد البحراوي - العروض وإيقاع الثعر العربي محاولة لإنتاج معرفة علمية -الهيئة المصرية العامة

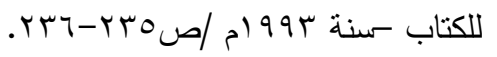


د. يوسف عباس علي حسين

والتتسيق الصوتي ونخضع لقانون التوافق والتماثل الصوتي ، أمسا الموسيقى الخفية فإنها

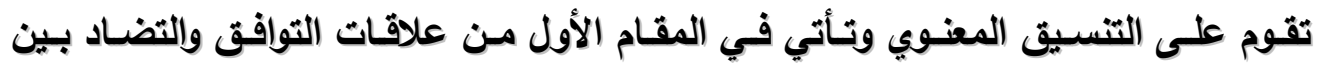

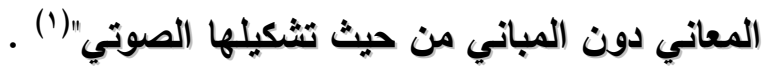

وتوجد موسيقى القصيدة في " هيكلها العام ، وهذا الهيكل يتألف من نمطين ، نمط ديط

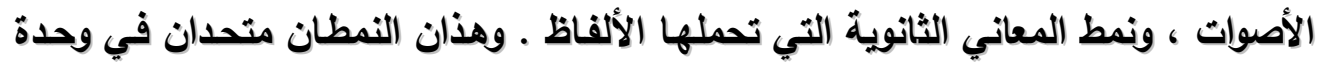
لا يمكن انفصـامها ، فمـن الخطأ الادعاء بـأن موسيقى الثـعر تنشـأ مـن صـوته المجرد

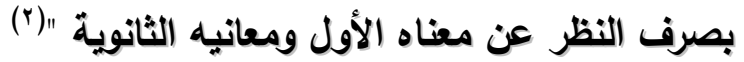
كما نجد الرموز والأفكار في داخل النص ، فيقول الثـاعر في انتظار اليسر بعد العسر: - (ال

يبلى ويصبر والأشياء تنتهج مستشعر الصبر مقرون به الفرج جاءتك تضحك من ظلمائها السرج حتى إذا بلغت مقدور غايتها

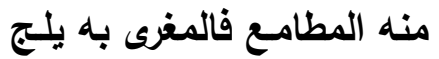
فاصبر ودم واقرع الباب الذي طلعت معدور عالته

ففي إرادته الغماء تنفرج(") يقدر الله فارج الله وارض بـه وابه

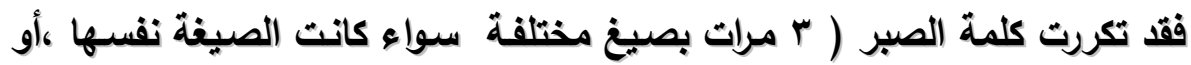
ما يشتق منها فتعطى جرساً موسيقياً يترك صدى في النفس) في الأبيات السابقة ، وتكرار

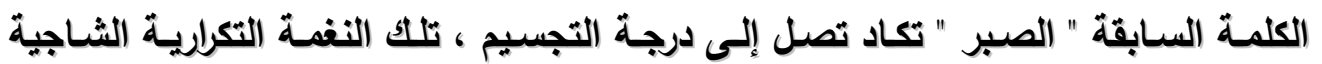
تبرز الإيقاع في القصيدة . كما أنه أكثر من استخدام الأفعال المضارعة " يبلى -يصبر-تنتهج- تضحك-يلج-

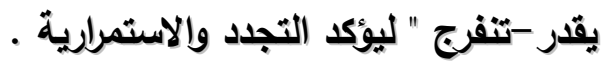
والتكـرار يسـاعد في تقويـة النبرة الخطابيـة، وتمكين الحركـات الإيقاعيـة، فيقول العطوي معتزاً بعلمه وأدبه: رضا علماء لا تسخط جهال رضينا بحكم الله بين عباده وبهن

( (1)حسني عبد الجليل يوسف -موسيقى الشعر العربي "دراسة فنية وعروضية "-الهيئة الكصرية العامة للكتاب

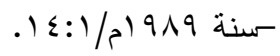

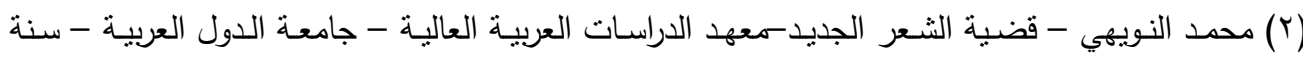


مُستويات الإيقاع في شعر العطوي "من الصوت إلى النص"

لئن خص قوماً بالنباهة وإلغنى وألبسنا ثويى خمول وإقلال

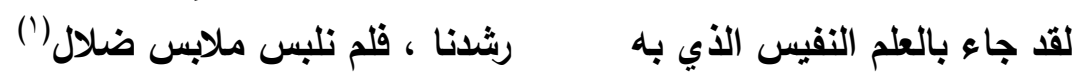

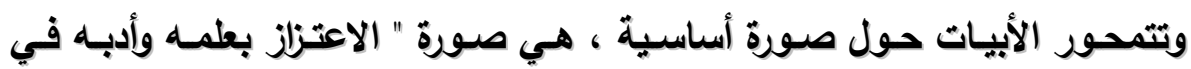

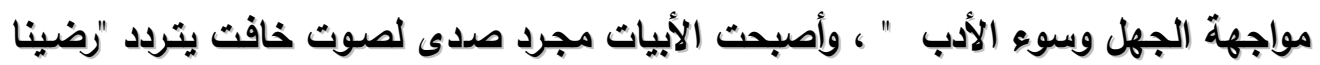

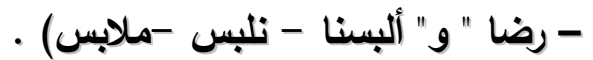

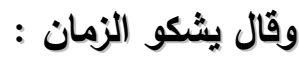
س ويؤس ومحنة وصغار
هو في حيرة وضنك وإفلا

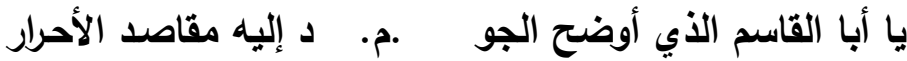

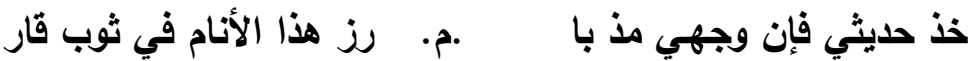

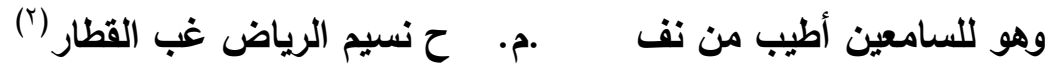

فتكرار الضمير " هو " قد حقق تناسبًا وتلاؤمًا في الأبيات من خلال التلاحم

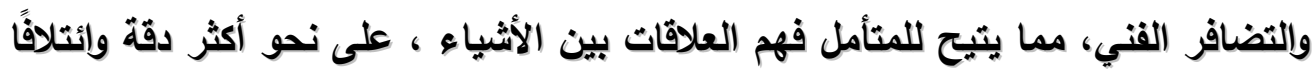

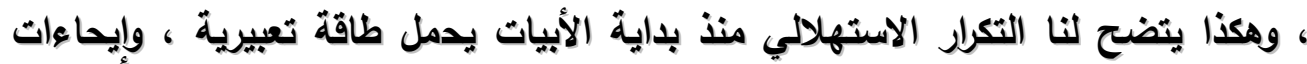
خاصّة ، تومئ إلى ائتلاف الصور وتمازجها بشكل إيقاعي منظم .

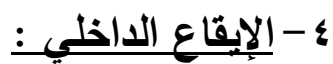

تعد الجملة ، أو الوحدة والمستوى الصوتي أساس الإيقاع الإخلي ، ولا يمكن لأي

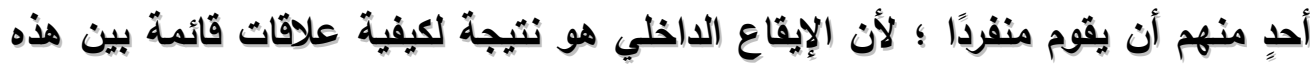

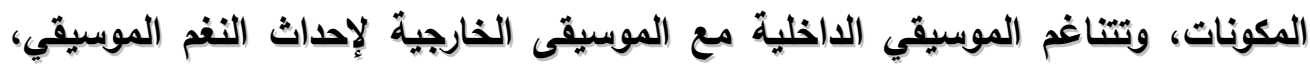
وإيجاد البنية الإيقاعية للقصيدة .

ولأن الصلة وثيقة بين الثعر والموسيقى ، وتتحقق البنية الإيقاعية الجديدة ، فالإيقاع الداخلي هو : "موسيقى خفية تتبع من اختيار الثاعر لكلماته وما بينهما من تلاؤم

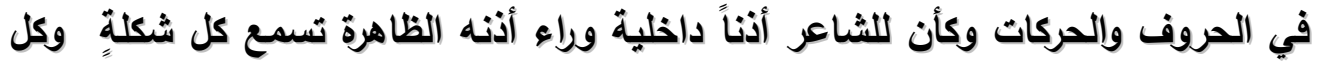
حرف وحركة بوضوح تام ـ ويهذه الموسيقى الخفية يتفاضل الشعراء " (").

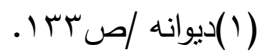

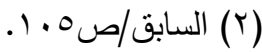

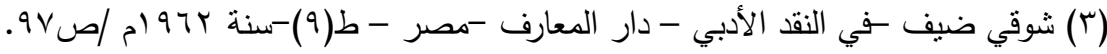

$$
\begin{aligned}
& \text { - }\{Y \mid \text { - }
\end{aligned}
$$


د. يوسف عباس علي حسين

ويمكن استثمار القيم الإيقاعية ودلالتها التي تنطوي عليها بنية الإيقاع الداخلي

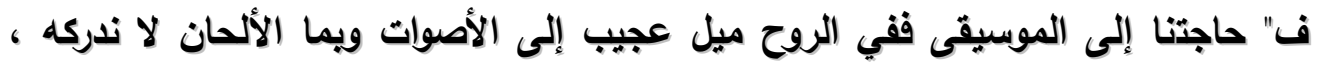

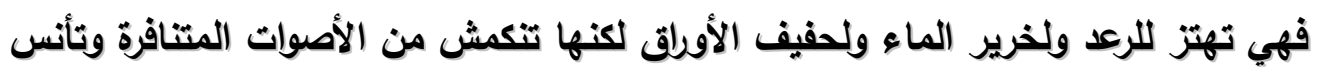

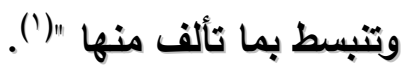

وينتج الإيقاع الداخلي عن " حسن استغلال الثاعر للخصائص الصوتية للغة

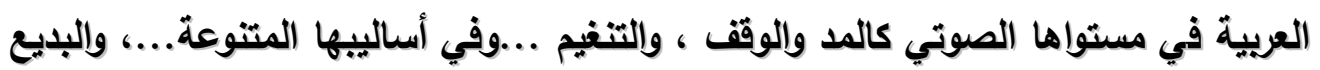

من تصريع وقافية داخلية ، فلا معنى لإيقاع خارجي فارغ من الإيقاع الداخلي" (بات.

وقد تحققت الموسيقى الداخلية في شعر العطوي " وذلك من خلال ملاعمة ألفاظه

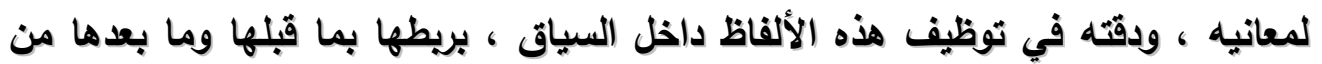

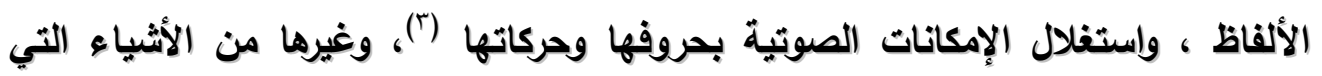

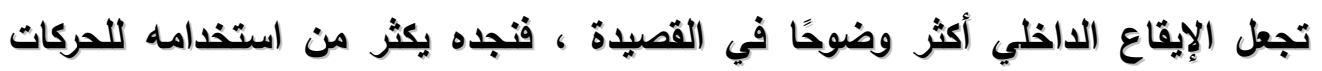

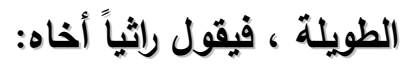

وزفقته للمنزل المهجور حنطته با نصر بالكافور

فيضوع أفق منازل وقبور هلا بيعض خصاله حنطته

يعزي إلى التقديس وإلتطهير تالله لو من نشر أخلاق له له فصناله

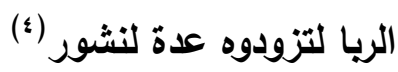

حنطت من سكن الثرى وعلا

فاستخدم الثاعر في الأبيات السابقة حروف المد الطويلة ،منوعاً بين أصوات المد

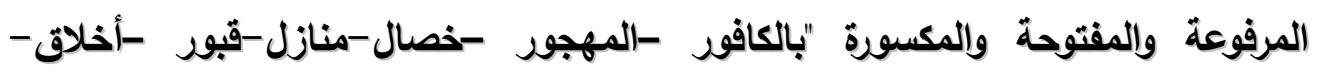
التقديس -التطهير - الريا-لنشور" لتشكل خطوطًا صوتية متجانسة تحقق من خلالها

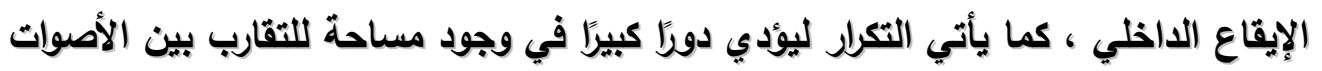

$$
\begin{aligned}
& \text { (I محمد منـدور -محاضـرات في الثـعر المصـري بعد شـوقي -معهد الدراسـات العربيـة - القاهرة سـنة } \\
& \text {.1. } 1900 \\
& \text { برباق ربيعة -الإيقاع الثعري " دراسة لسانية جمالية "- مجلة كلية الآداب والعلوم الاجتماعية -جامعة }
\end{aligned}
$$

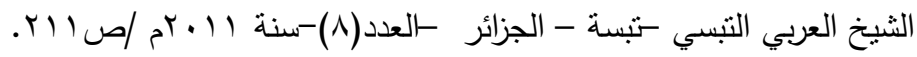

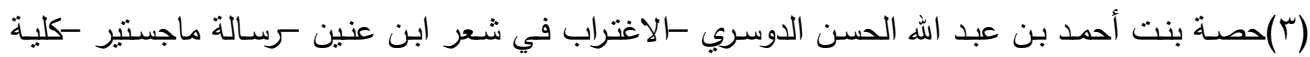

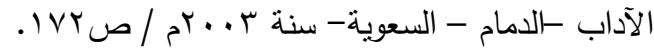

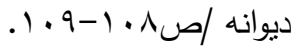



مُستويات الإيقاع في شعر العطوي "من الصوت إلى النص" -

ولكي يزيد من وقع المفردات الشعرية ، ويعمق حضور الكلمات في داخل النص من أجل توليد مزيد من الانسجام في نسق الأصوات. ويرتبط تكرار الأصوات أيضاً بالجناس ، وهو " يتمثل كمات هو هو معروف في تكرار

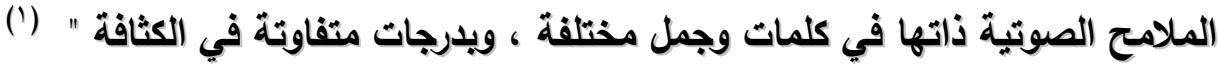
ومن نماذج الجناس في شعر العطوي في قوله :

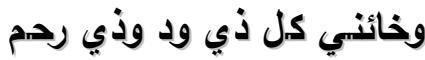
لما أنساخ على الاهر كلنهله

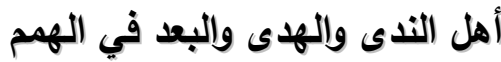
ناديت :ما فعل الأحرار كلهم

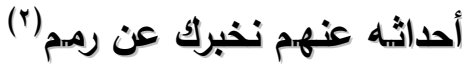
قالوا:حدا بهم ريب الزمان، فسل فنجد تكرار الجناس في " ناديت - الندا "تثابهت بعض الحروف ، وهذا فئ الجناس أضفى

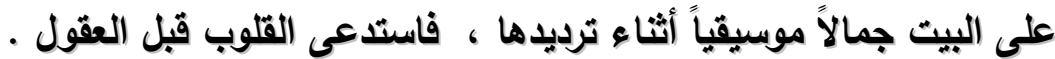
وقد استخدم الثاعر في قوليه :

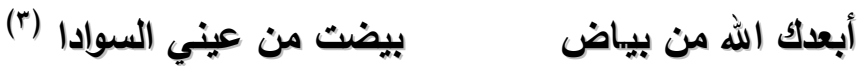

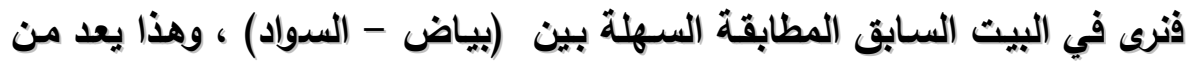

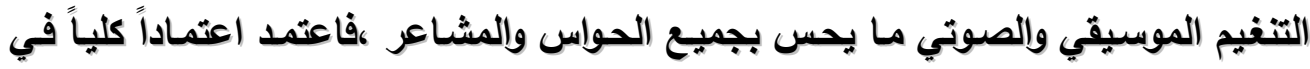

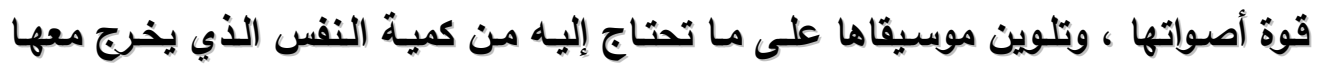

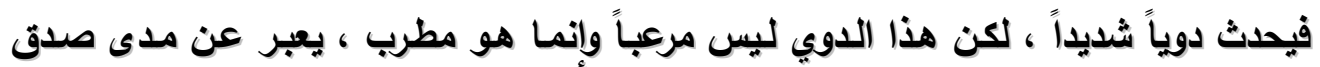
الشاعر فيما هو بصدده ، وهناك تنغيم آخر في قوله :

رضا علمهاء لا تسخط جهال رضينا بحمم الله بين عباده

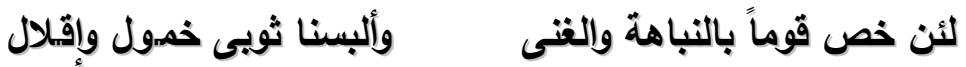

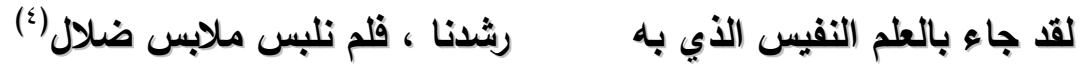
وقد ورد عند العطوي شعر يعطي نغمـة موسيقية سريعة ، ومباشرة ،ويدل دلالة كبيرة

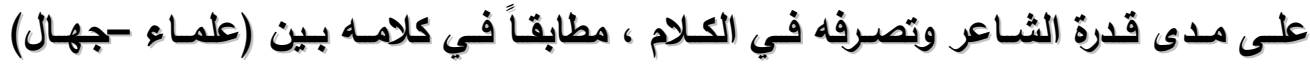
،واستطاع تطويع الألفاظ ، بحيث لا يخلو كلامه من حسن موقع السمع في قوله :

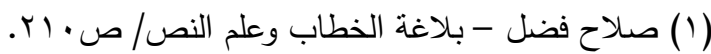

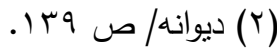

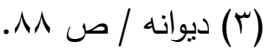

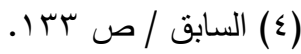


د. يوسف عباس علي حسين

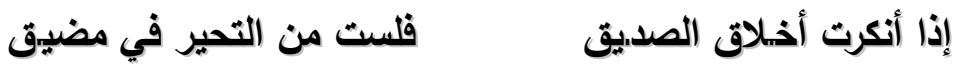

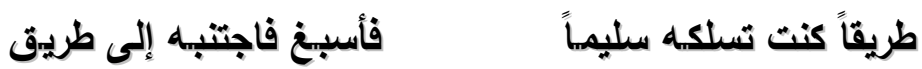

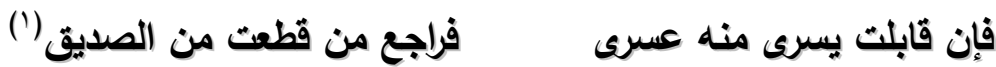

فرصع العطوي أبياته بكلمات ( الصديق-مضيق) جانحاً إلى هذين الكلمتين لإحداث

نغمة موسيقية ، وورد في سياق عتابه للخليفة المعتضد عندما أقام بسنجار وترك بغداد:

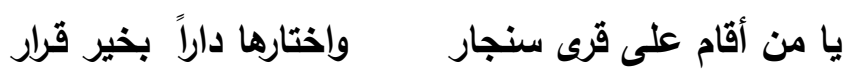

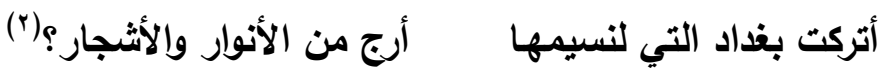

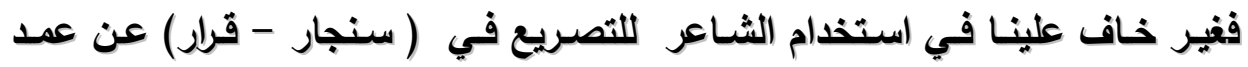

وقصد لا مجرد الحلية اللفظية فحسب ، وإنما لتوضيح شدة العتاب بينه وبين الخليفة . ويقول الشاعر في التغزل بالغلمان :

يسحر من مقلته السحر

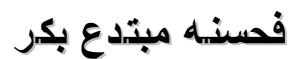

يفطر من وجنتيه الحمر

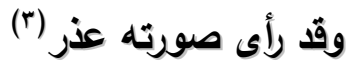

أحور في أجفانه فتر فئر

ما نكعت حسناً له نظرة

يكاد إن أخجله ميازج

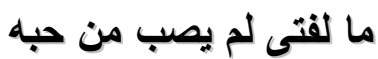

لقد استخدم الشاعر في البيث الأول ، فجاء في المصراع الأول (فتر) وقابله في

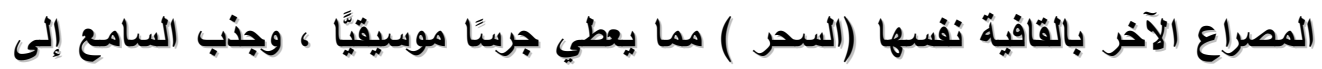

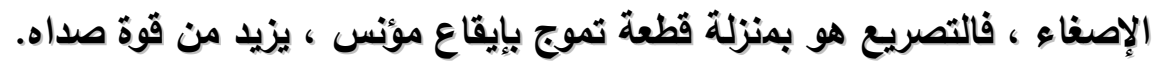

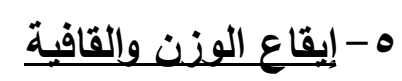

تعد موسيقى الثعر العربي عنصراً جوهرياً في تثكيل النص الشعري ، يقوم بوظيفته

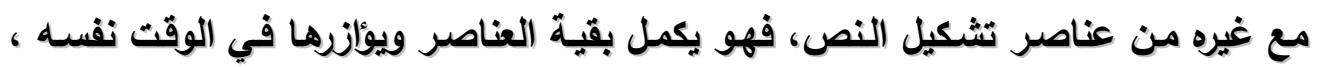

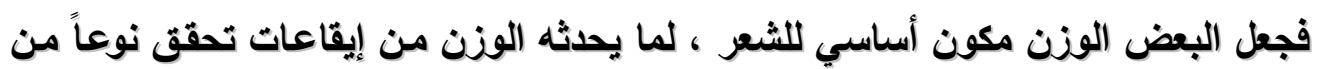

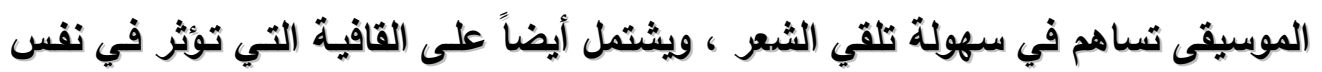
المتلقي.

ولقلد عرَّف قدامة الشعر بأنه :" قولٌ موزونُّ ومقفّى يدل على معنى " (')

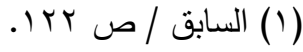

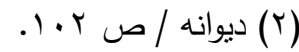

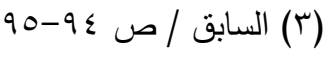


مُستويات الإيقاع في شعر العطوي "من الصوت إلى النص" ــ

فالوزن عند قُامـة مقدمٌ على المغنى ، والمزن " هو مجموع التفعيلات التي يتألف منها

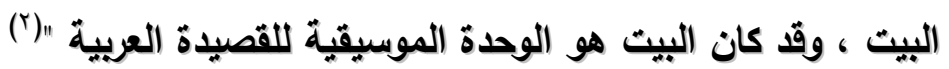

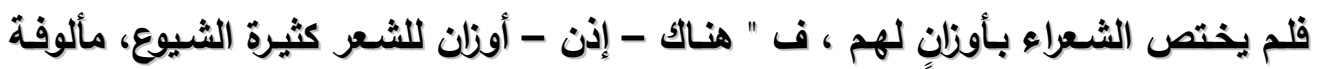
محبوية ، يطرقها كل الشعراء ، وينسجون عليها معظم أشعارهم.

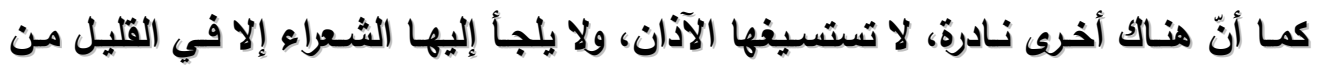

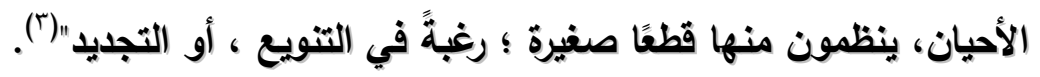

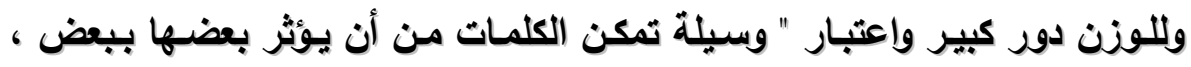
فإنه يسعى لتوفير هذا بإثارة الحيوية والقابلية لدى كل المشاعر العامـة ، والانتباه معتمداً

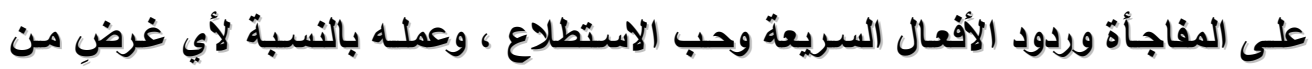

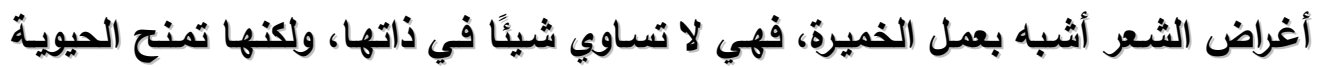

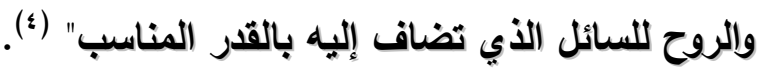
ولقد نشأ العطوي في العصر العباسي الذي بلفت فيه العضارة ذابل اروتها ، فما كان

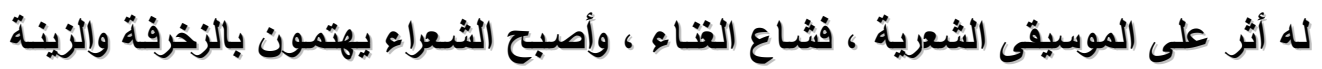

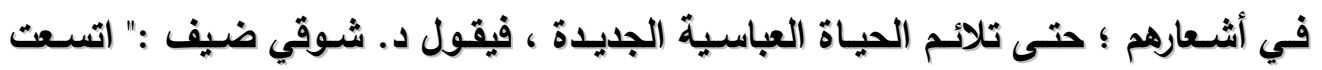

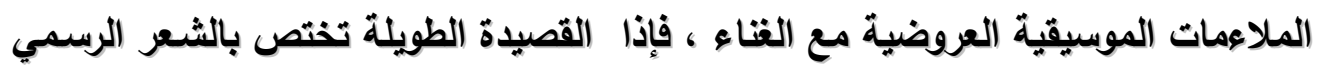
، شعر المديح والرثاء ، بينما تثيع المقطعات في الغزل والهجاء والمجون والزهد والحكم ،

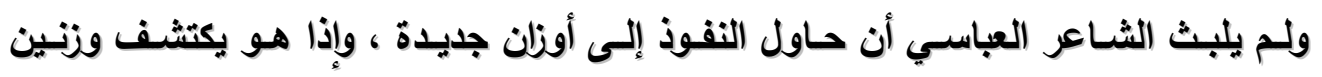
سجلهما الظليل بن أحمد حين وضع نظرية العروض ، وهما وزنا المضارع والمقتضب " (0).

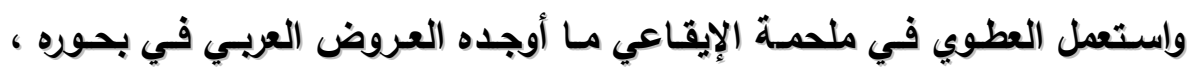
فاعتمد على البحور الطويلة في شعره ، وذلك يرجع إلى أنسه كان يجري على تقليد الثـعراء

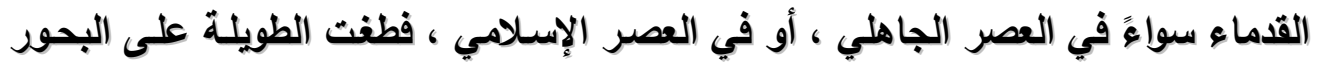

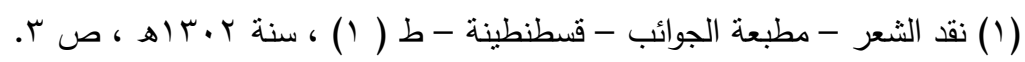

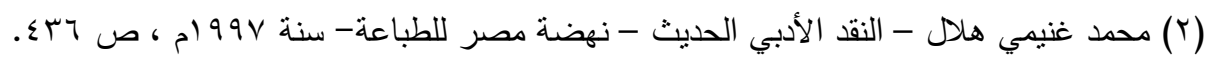

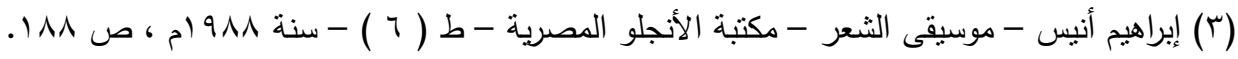

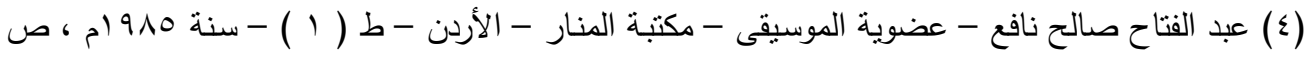

$$
\text { (0) شوقي ضيف - تاريخ الأدب العببي - العصر العباسي الأرل ، ص سو 19 - ع 19. }
$$


د. يوسف عباس علي حسين

القصيرة ، وآثر العطوي في نظم شـعره عشرة بحور بتامها ومجزوئها ، والجدول التالي

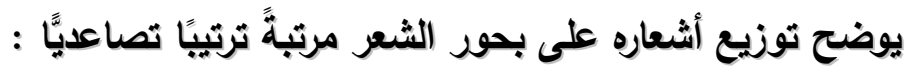

\begin{tabular}{|c|c|c|}
\hline التام & المجزوء & البحر \\
\hline r & - & المجتث \\
\hline- & $\varepsilon$ & الرجز \\
\hline- & - & السريع \\
\hline$\varepsilon$ & - & المنسرح \\
\hline v & - & المتقارب \\
\hline v & - & الكامل \\
\hline 9 & $r$ & الوافر \\
\hline 11 & - & الطويل \\
\hline 17 & 1 & الخفيف \\
\hline IV & $r$ & البسيط \\
\hline
\end{tabular}

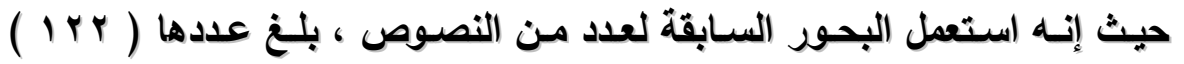

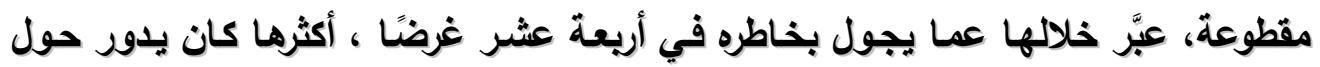

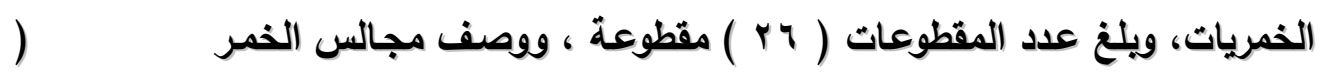

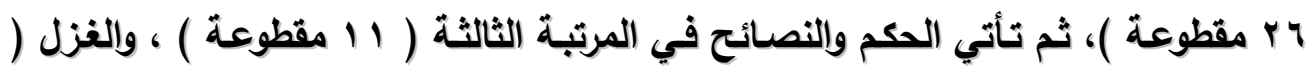

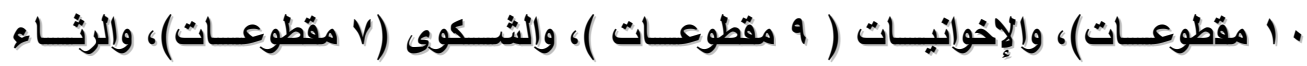

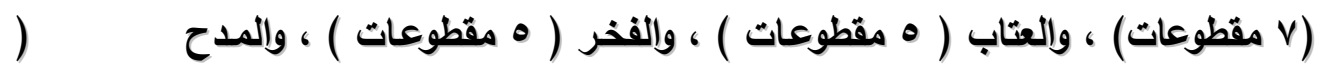

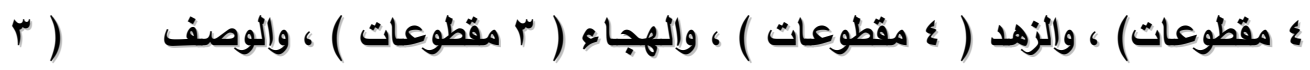

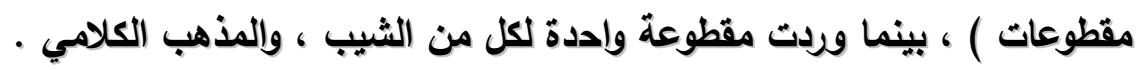

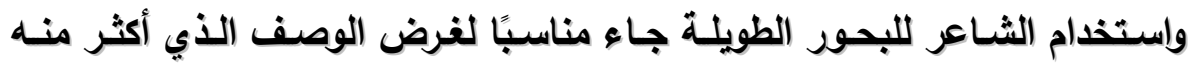
الشاعر ، فالشاعر وُفق في استخدامه للبحور ، فكل بحرٍ استخدمه بحسب مـا ينسجم مـع

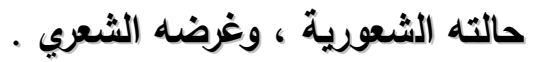
القافيـة: 
مُستويات الإيقاع في شعر العطوي "من الصوت إلى النص" -

تُعدّ القافية الركيزة الثانية للشعر ، فالقافية " هي الساكنان آخر البيت ، ومـا بينهما

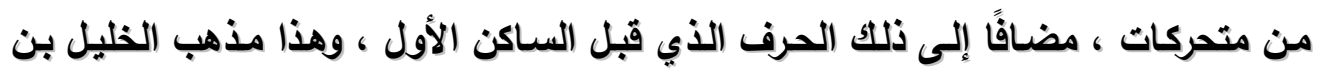

(') أحمد " (')

أما سبب تسميتها بالقافية ( لكونها آخر البيت ، مأخوذة من قوبك : قفوت فلانًا

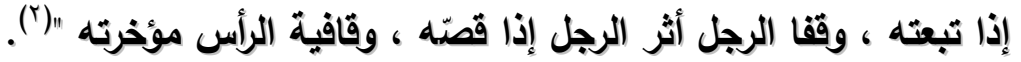

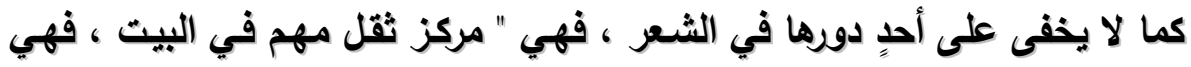

حوافر الشعر ومواقفه ، إن صحت استقام الوزن وحسنت مواقفه ونهاياته "("َ).

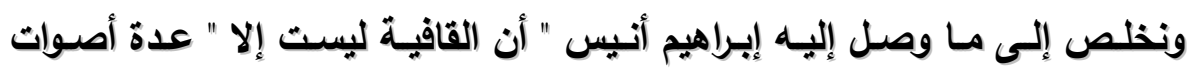

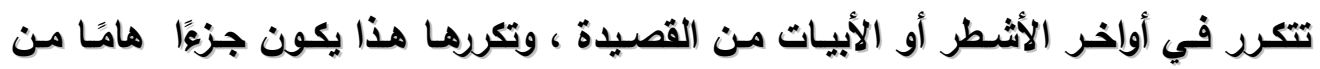

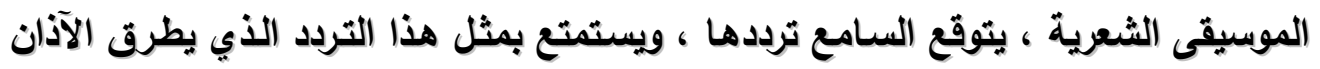

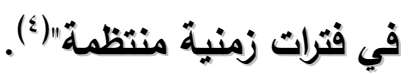

أما عند الحديث عن أنواع القافية ، فهناك قافية مقيدة ، وأخرى مطلقة ، فالقافية

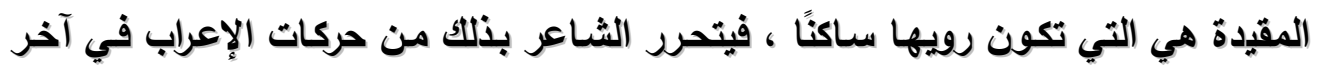
القافية ، والقافية المطلقة هي التي يكون رويها متحركًا ، وإلنوع الأول على حلى حلاوته أحياتًا

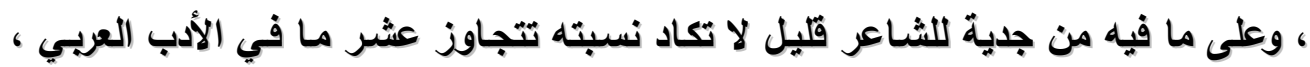

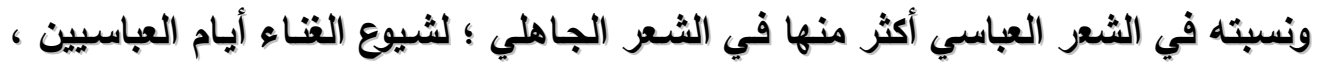

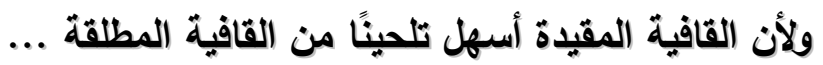
أما القافية المطلة فقد يكون رويها محركًا بالضمة ، أو الفتحة ، أو الكسرة "(•).

(1) عبد الحمبد الراضي- شرح تحفة الخليل في العروض والقافية - مطبعة القاضي - بغداد - سنة 971 ام r

(Y) القاضي التتوخي - القوافي- تحقيق : عوني عبد الرعوف - مكتبة الخانجي - مصر - ط ( r ) ، سنة

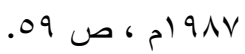

(ץ) جابر عصفور - مفهوم الثـعر " دراسـة في التراث النقدي " - الهيئة العامـة للكتاب - ط (0) - سنة ( ) 1990 199

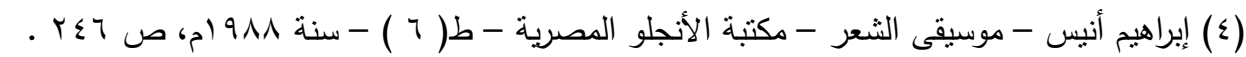

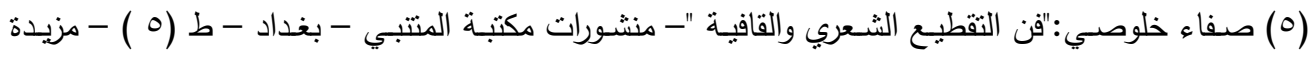

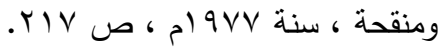


أما إذا نظرنا إلى قوافي العطوي ، فنجدها موحدة ، ولم يخرج عنها ، على الرغم

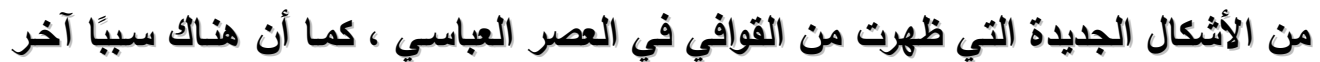

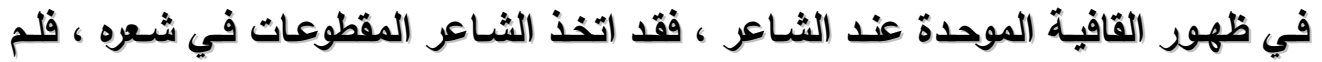

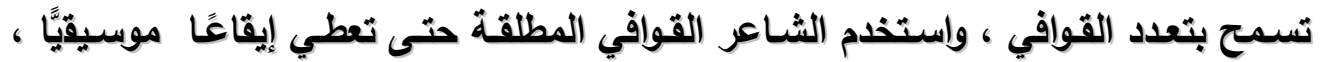
فيقول الندمان الغارق في المدام : وندمان صدقي أدرت الكئوس

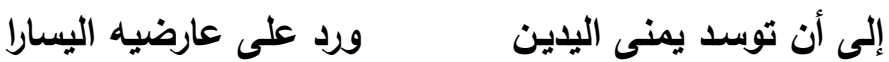

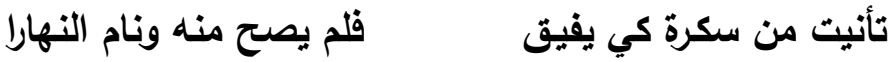

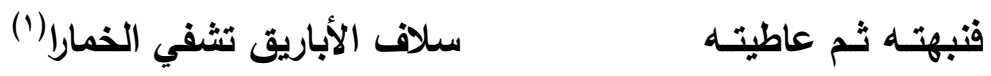

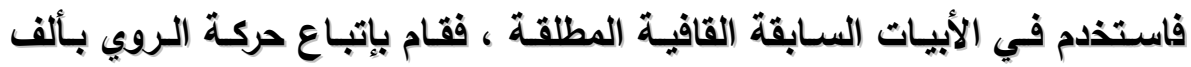
الإطلاق ، كما استأثر الضمة والكسرة بالنصب الأكبر لما يتمتعان هذين الحركثين بقيمةٍ جماليةٍة كبيرةٍ .

ويقول في وصف مائدة من موائد الشراب ، واصفًا لجوها ووقتها :

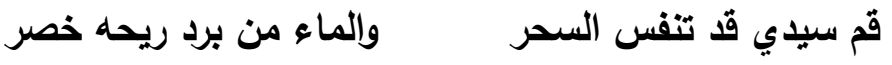

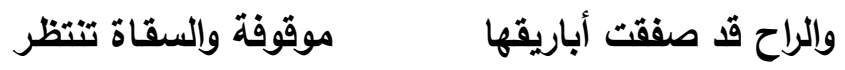
وزهرة أشرقت مصابحها لولا الندى طار حولها شرر دنا إليها في الليل مقتبس لما رآها كالنـار تستعر

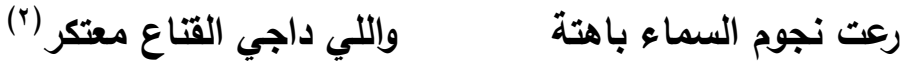
وقد وردت القافية ذات الروي المكسور عند شاعرنا ، فقال يشكو الزمان : أين الوفاء الأي كان يعرفه؟

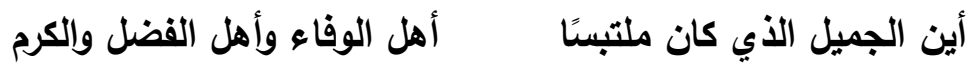

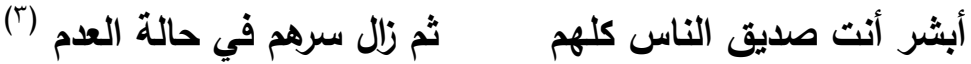
كما قام العطوي بتشبيع حرف الروي ، فتأخذ الكسرة ياءًً ، والضمة واوًا ، والفتحة ألفًا ، حتى تكون أكثر تأثيرًا في المتلقي ، فيقول :

$$
\begin{aligned}
& \text { (1) ديوانه ، ص (Y (1) } \\
& 97 \text { (Y) } 90
\end{aligned}
$$

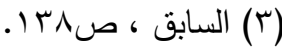


مُستويات الإيقاع في شعر العطوي "من الصوت إلى النص" ــ

$$
\begin{aligned}
& \text { كنت المُعزَّى بفقدي }
\end{aligned}
$$

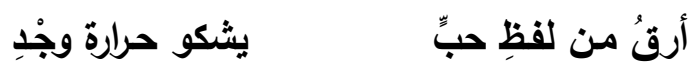

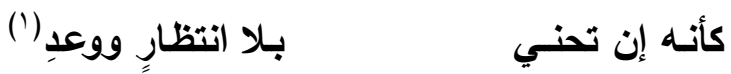

كما آثر العطوي في شعره الحروف التي تتسم بالجرس الموسيقي الجميل ، والنفم

$$
\text { الجذّاب ، فاستخدم حرف الراء في قوله : }
$$

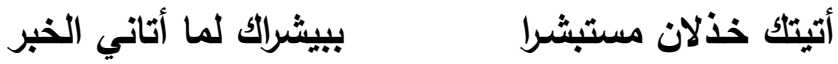

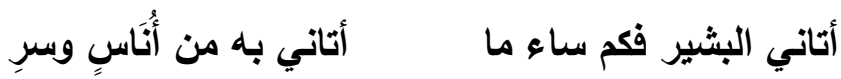

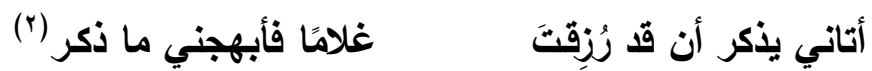

وقوله في شكاية الإخوان الذين لم يحسنوا معاملة الخلان :

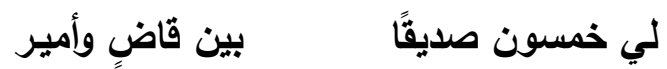

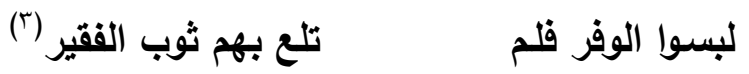

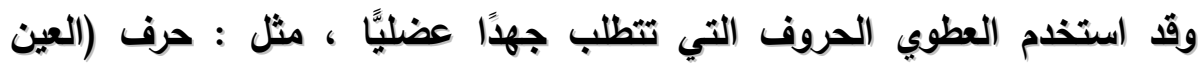
والقاف واللهزة والجيم وإلفاء ) ، فقال في قافية العين :

بحبل ودِّ فلا ذئب ولا ضبعُ

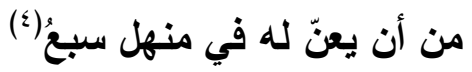

دنا وردها ترعى النجيل من الحمض

حداثهم بين القرينين فالعرض

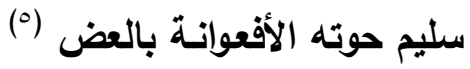

كبنت الخدر في طيبٍ المذاق

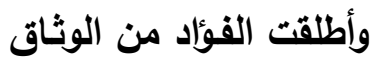

أقصد إلى ود شئت معتصمًا

المالُ أعضبُ سيفٍ عند صواته

ومن قوافي حرف الضاد في قوله :

فما ازدحمت عير على ورد منهلٍ

تزاحم دمعي في الجفون وقد غدت

وقد تركوني في الايسار كأنني ومن قوافي حرف القاف :

وطيبة المذاق بنت خدرِ

قصرت بشربها عمر الملاهي

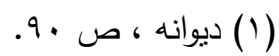

$$
\begin{aligned}
& 9) \text { (Y) السابق (r) }
\end{aligned}
$$

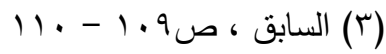

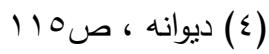

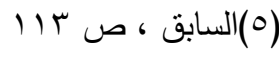


د. يوسف عباس علي حسين

أغاديها على شدو الأغاني مع الوصفاء في البعض الرفاق( )

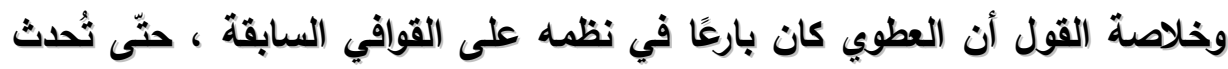

خفّةً ونغمًا تتقبله الأذن . 


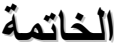

ويعـد، فقد قضسى لهـذا البحـث أن يبحر عبر حيـاة شــاعر كـان مـن الشـعراء

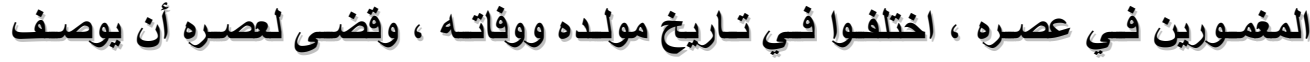

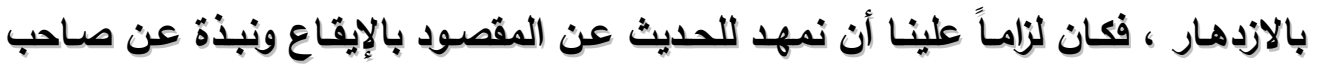

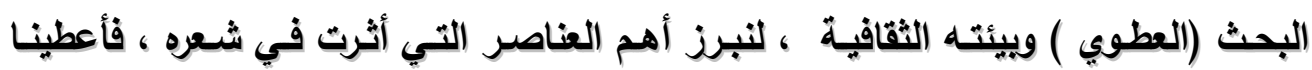

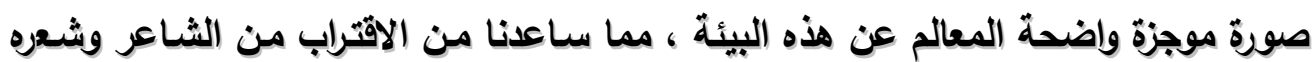
، ومعرفة الإيقاع ومُستوياته المختلفة من خلال شعره .

وقد تحققت في الفصل الأول أثنـاء حديثي عن شـعر العطوي مضـامينه الفنية (إيقاعية

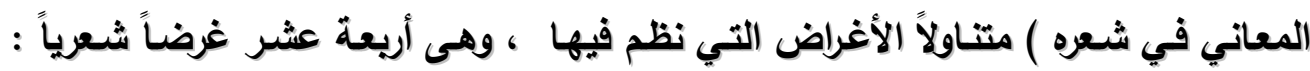

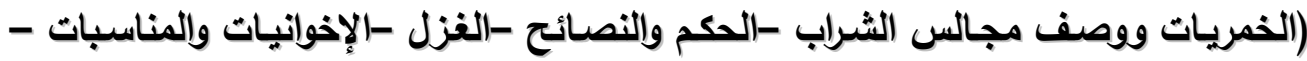
الشكوى -الرثاء - العتاب -الفخر -المدح-الزهديات - الهجاء -الوصف -الثيب- شعر -لاجئ

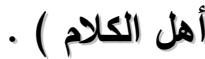

الفصل الثاني : تنـاول الباحث مُستويات الإيقاع مقدماً بتمهيد عن موسيقى اللفـة عند

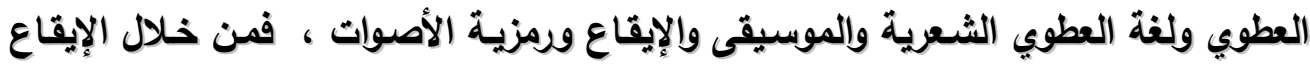

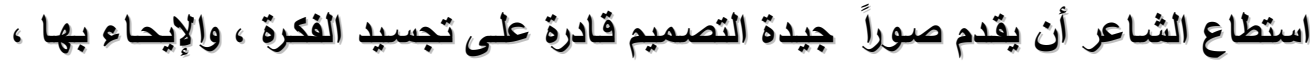

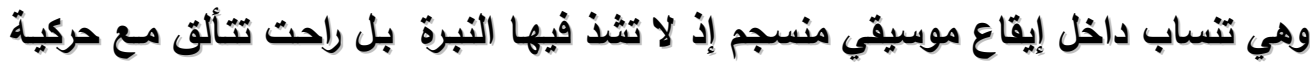

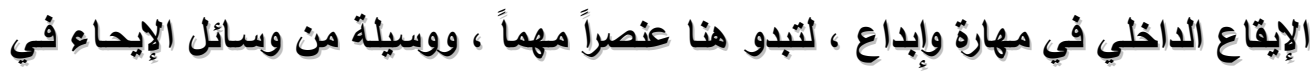

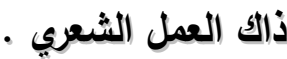

وقد تمتعت تجربة العطوي برصيدها في بناء العمل الثعري ، ومن هنا فإن عمله الثعري

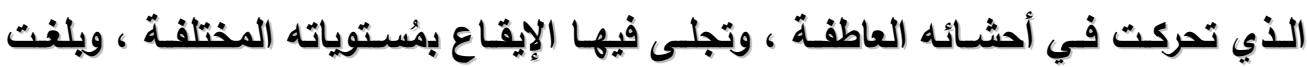
الصياغة الفنية مداها من الروعة والمتعة

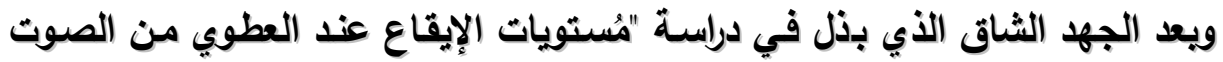
إلى النص " توصل الباحث إلى جملة من النتائج التي تمخض عنها البحث ، منها : - يعد غرض الخمريات ووصف مجالس الشراب من أكثر الأغراض وروداً ، حيث نجد أكثر من ريع مقطوعاته في هذا الغرض وحده حتى عده محقق الديوان من شعراء الخمريات

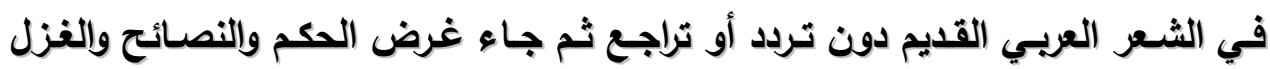


د. يوسف عباس علي حسين

والإخوانيات والمناسبات ...إلخ،حيث إن المجتمع العباسي ورث هذه العادات من لهو

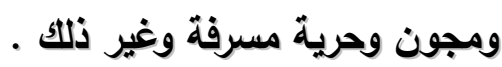

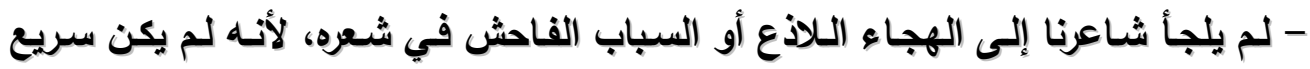

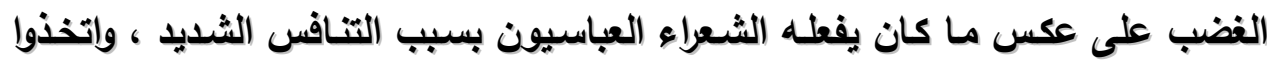
منه سهاماً يوجهونه لكل مثلبة خلقية أو نفسية.

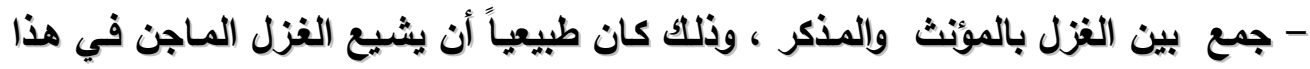
العصر . - لم يكثر من شعر المدح كغيره من شعراء عصره ، فلم يمدح الخلفاء والأمراء على الرغم

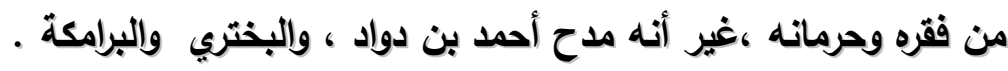

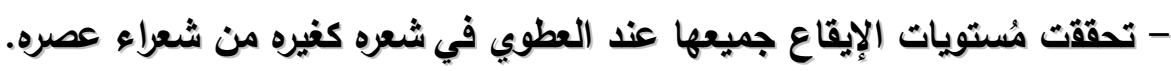

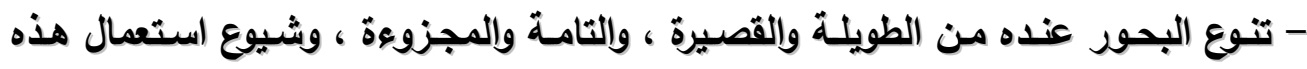

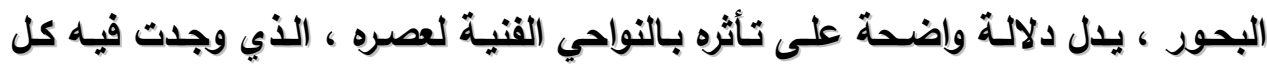
البحور.

- استخدامه للبحور الثعرية الطويلة ، يرجع إلى أنه يجاري التقليد الثعري المتعارف عليه عند الشعراء الجاهليين والعصر الإسـلاهي ، بينما كان بجاري عصره (العصر العباسي) بلهي باستخدامه البحور المجزوءة ، استجابة لمتطلبات الغناء .

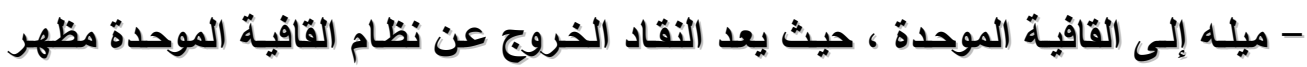

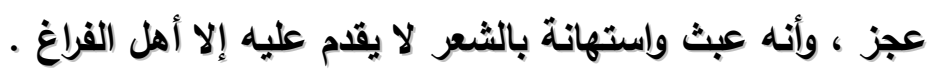

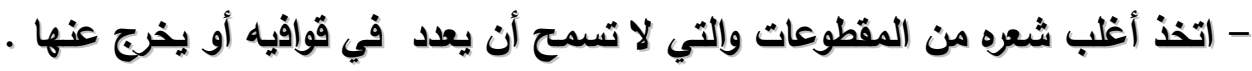

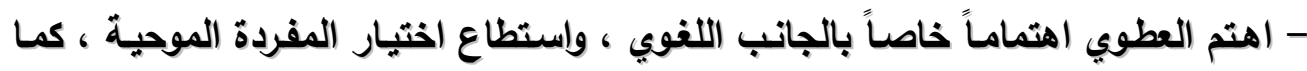

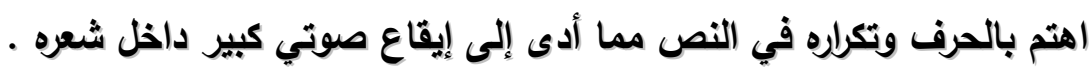

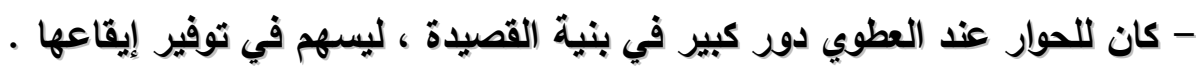

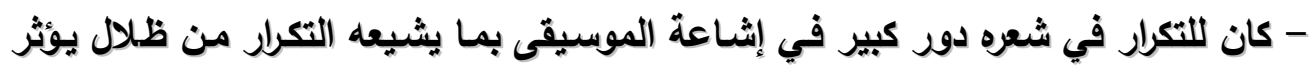
في نفس القارئ والسامع . 


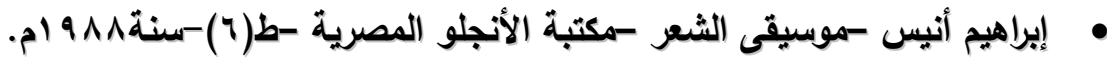

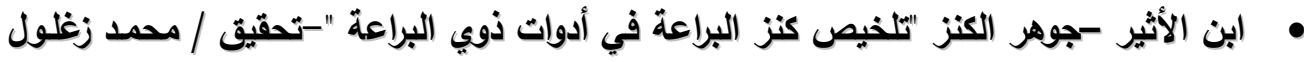
سلام -ط شركة الإسكندرية للطباعة والنشر -(د.ت).

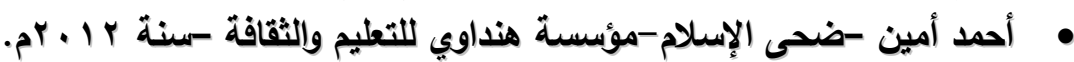

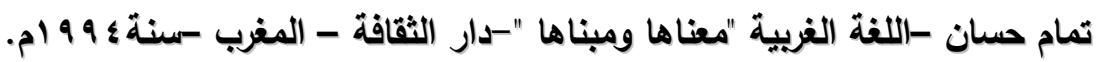
تمام حسان - مقالات في اللغة والأدب - عالم الكتب -(د. .ت).

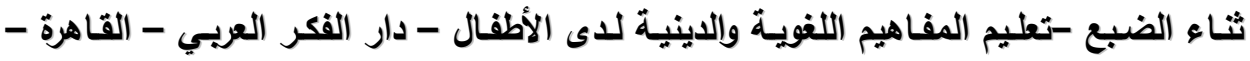

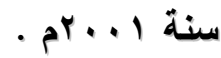

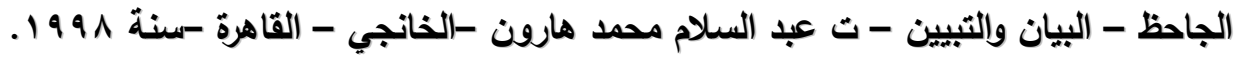

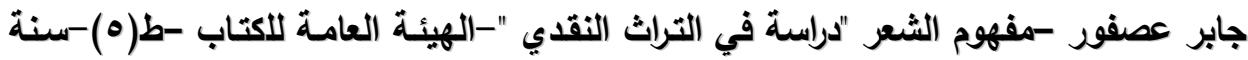
. طازم علـي كمـال الدين -نظريـة المناسبة الإيقاعيـة في القافيـة -مكتبـة الآداب - القاهرة -

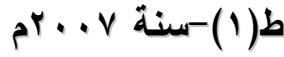
حازم القرطاجني - منهاج البلغاء وسراج الأدباء -تحقيق محمد الحبيب بن الخوجة - الدار

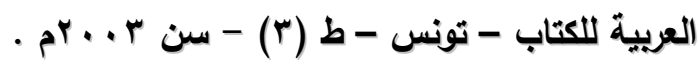

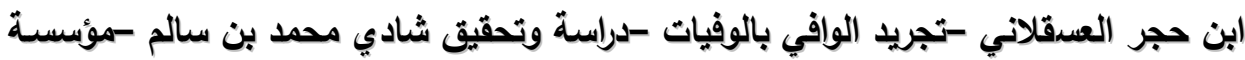

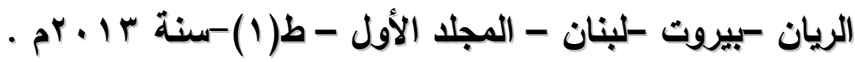

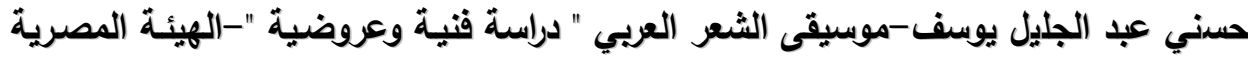

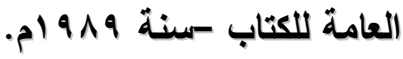

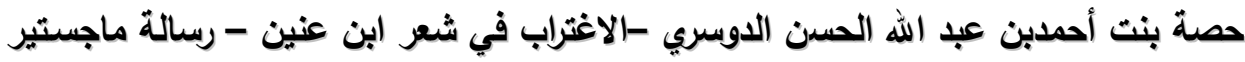

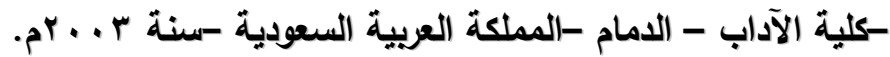

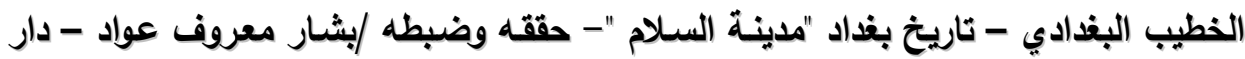

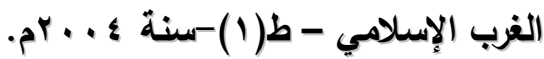
ابن خلكان - وفيات الأعيان وأنباء أبناء الزمان بان -تحقيق إحسان عباس -دار صادر -بيروت

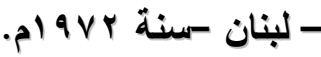
خير الدين الزركلـي -الأعـلام - دار العـم للملايسين - بيـروت - لبنـان - ط(0 ام ) - سـنة

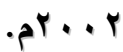
رومان جاكبسون -قضايا الشعرية - ت / محمد الولي مبارك وجنوز - دار تويقال - المغرب ،

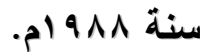
السعيد الورقي - لغة الثعر العربي العديث -دار المعارف - مصر ط (ץ) ،سنة به ام ام. 
د. يوسف عباس علي حسين

السمعاني -الأنساب -حقق نصوصه وعلق عليه / محمد عوامـة -ط(1) - مكتبة ابن تيمية -

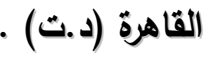

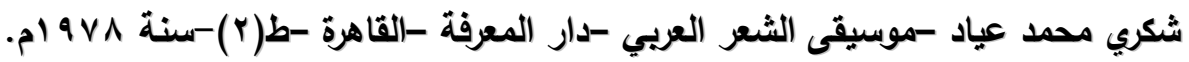

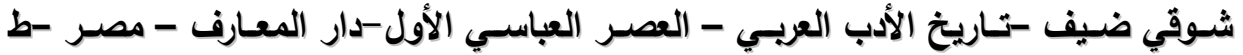

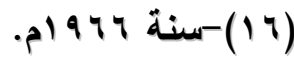

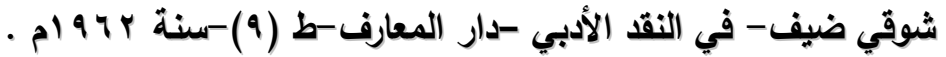

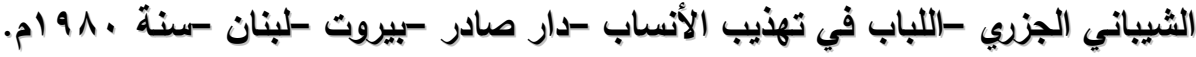
صاحب إبراهيم خليل -الصورة السمعية في الثعر في الثعر العربي قبل الإسلام -منشورات

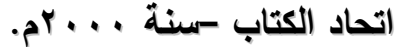
صفاء خلوصي -فن التقطيع الثعري والقافية -منشورات مكتبة المتنبي - بغداد -ط(ه)-سنة . 9 l $9 \mathrm{VV}$ صلاح الدين الصفدي -الوافي بالوفيات -تحقيق أحمد الأرناؤوط -مصطفى تركي -دار إحياء

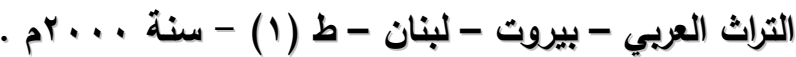
ابن طباطبـا العلوي -عيار الثـعر -شـرح وتحقيق عبد العزيز ناصر المـانع -دار العلوم

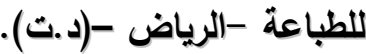
عبد الحميد الراضي -شرح تحفة الظليل في العروض والقافية -مكتبة القاضي -بغداد سنـة .01971

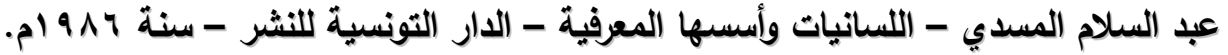

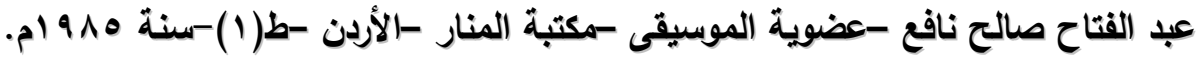
عبد القادر القط -الاتجاه الوجداني في الثـعر العريـي المعاصر -مكتبة الثايب - القاهرة -

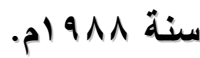
عز الدين إسـاعيل - الثـعر العربي المعاصر "قضـاياه وظواهره الفتبـة والمعنويـة" - دار

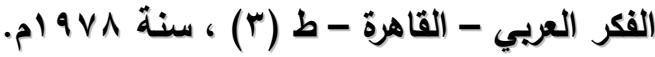
عفيف عبد الرحمن - معجم الثعراء العباسيين - دار صادر - بيروت - لبنان - ط (1) - ل

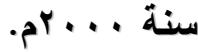
أبو العماد الامشقي - شذرات الأهب في أخبار من ذهب - تحقيق / عبد القادر الأرناؤو ط-

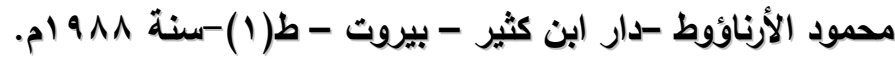

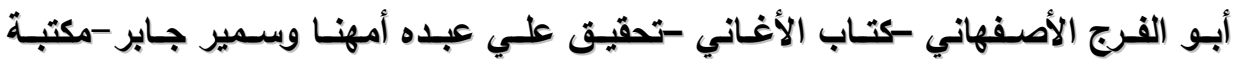
المصطفى الإكترونية -(د.ت). فردينان دي سوسير -علم اللغة العام - ترجمة يوئيل يوسف عزيز - دار آفاق عربية -بغداد

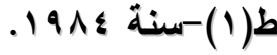



مُستويات الإيقاع في شعر العطوي "من الصوت إلى النص"

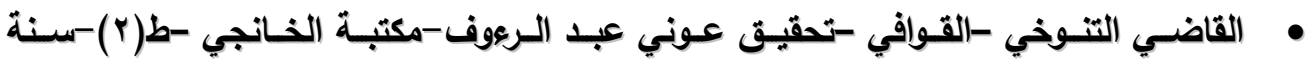

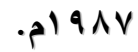

قدامة بن جعفر -فقه الثعر -تحقيق محمد عبد المنعم -مكتبة الكليات الأزهرية -ط(1)

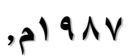

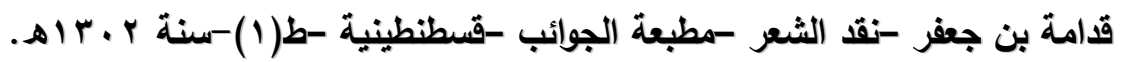

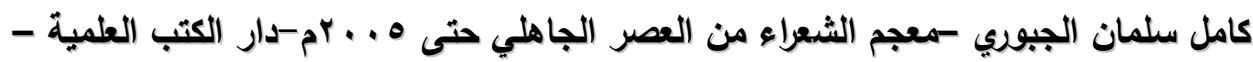
بيروت -(د.ت).

كمال أبو ديب -في البنية الإيقاعية للشعر العربي -الثؤون الثقافية العامـة -بغداد ط(r)-

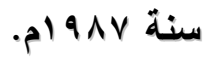
- محمد جبـار المعيبد - شـعر العطوي -دار المنظومـة -المجلـ (1) - العدد(1-r)-سـنة .

مجدي وهبة وكامل المهندس كمعجم المصطلحات العربية في اللغة والأدب - مكتبة لبنان -

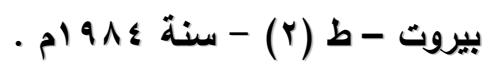

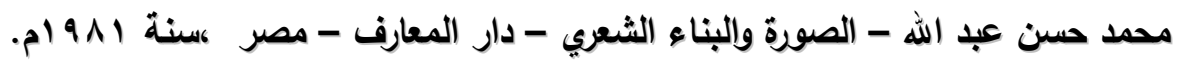

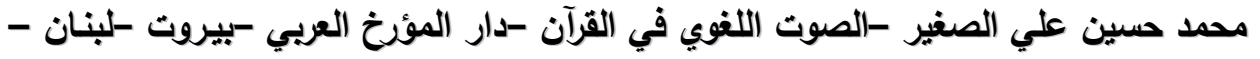

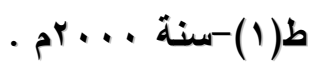

محمد عبد المنعم خفاجي - الحياة الأبيـة في العصر العباسي -دار الوفاء -الإسكندرية -

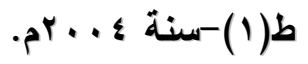
محمد عبدو فلفل - في التشكيل اللفوي للشعر " مقاريات في النظريـة والتطبيق " -منشورات

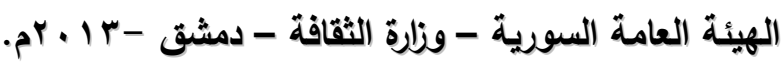

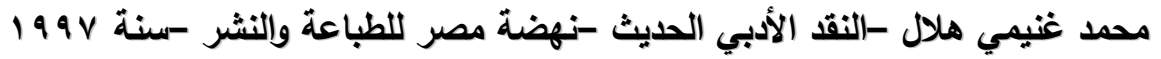

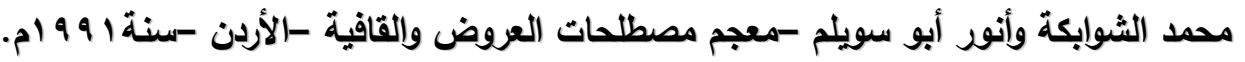

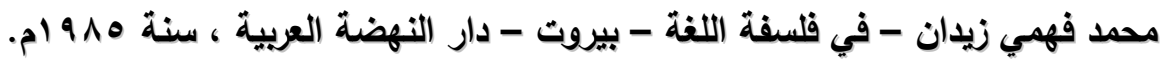

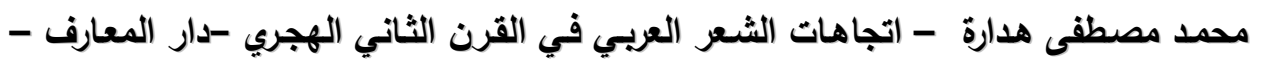

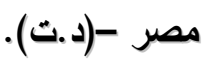
محمد مندور -محاضرات في الثعر المصري -بعد شوقي -معهد الاراسات العربية - القاهرة

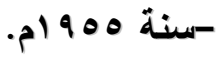
محمود فهمي حجـازي - أسس علم اللغـة - دار الثقافـة للطباعـة والنشـر-القـاهرة ، سـنة

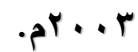
محمد النويهي -قضية الثعر الجديد -جامعة الدول العربية -معهر الدراسات العربية العالية سنة ؛ 97 ام. مصطفى جمال الدين - الإيقاع في الثعر العربي من البيت إلى التفعيلة -مطبعة النجف -

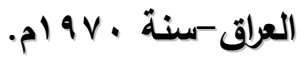
- $\leqslant$ Ho 


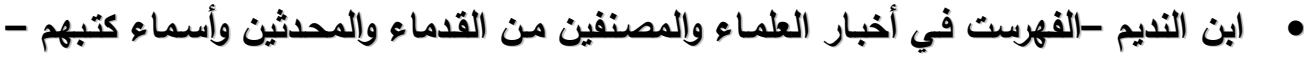

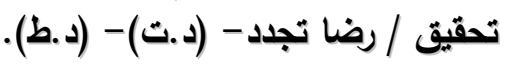

أبو نصر الفارابي -كتاب الموسيقى الكبير -تحقيق وشرح غطاس عبد الملك خشبة-دار الكاتب العربي للطباعة والنشر -القاهرة (د.ت).

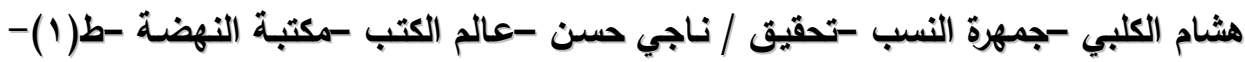

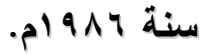
ياقوت الحموي -معجم الأدباء - تحقيق إحسان عباس -دار الغرب الإسلاهي -بيروت -لبنان

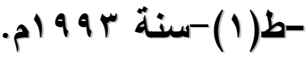
يحيي شامي -موسوعة شعراء العرب -دار الفكر العربي -بيروت (د.ته). الإوريات:

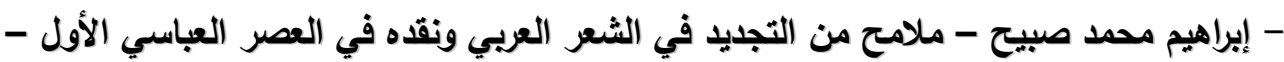

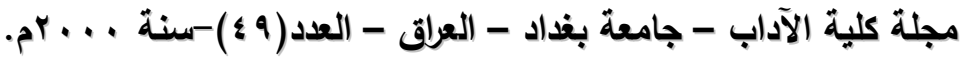
- برقاق ربيعة -الإيقاع الشعري"دراسة لسانية جمالية "-مجلة كلية الآداب والعلوم الاجتماعية -

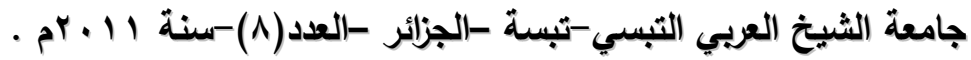

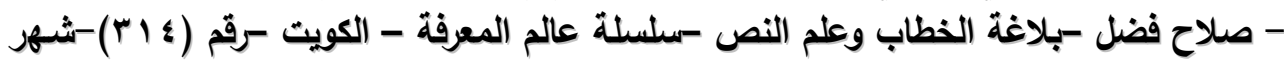

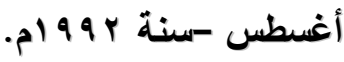

- محمد سعيد حسين مرعي - الحوار في الثعر العربي القديم شعر امرئ القيس أنموذجاً - كلية

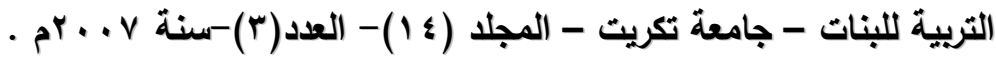

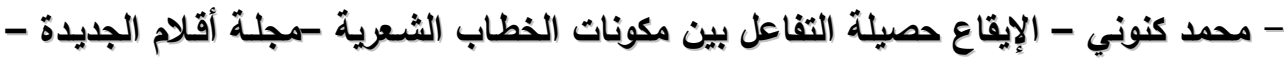

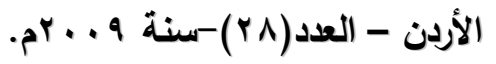

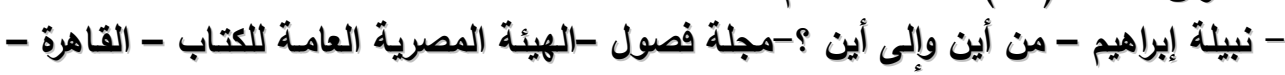

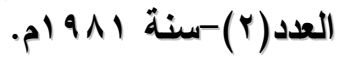
الادواوين الشعرية : الثينة

- العطوي -ديوانـه -تحقيق /عطية محمود حسانين -مكتبـة الآداب - القاهرة -ط(1) -سنة . 